\title{
Development as Leadership-led Change
}

\author{
Matthew Andrews, Jesse McConnell, and Alison Wescott
}

CID Working Paper No. 206

October 2010

(C) Copyright 2010 Matthew Andrews, Jesse McConnell, and Alison Wescott and the President and Fellows of Harvard College

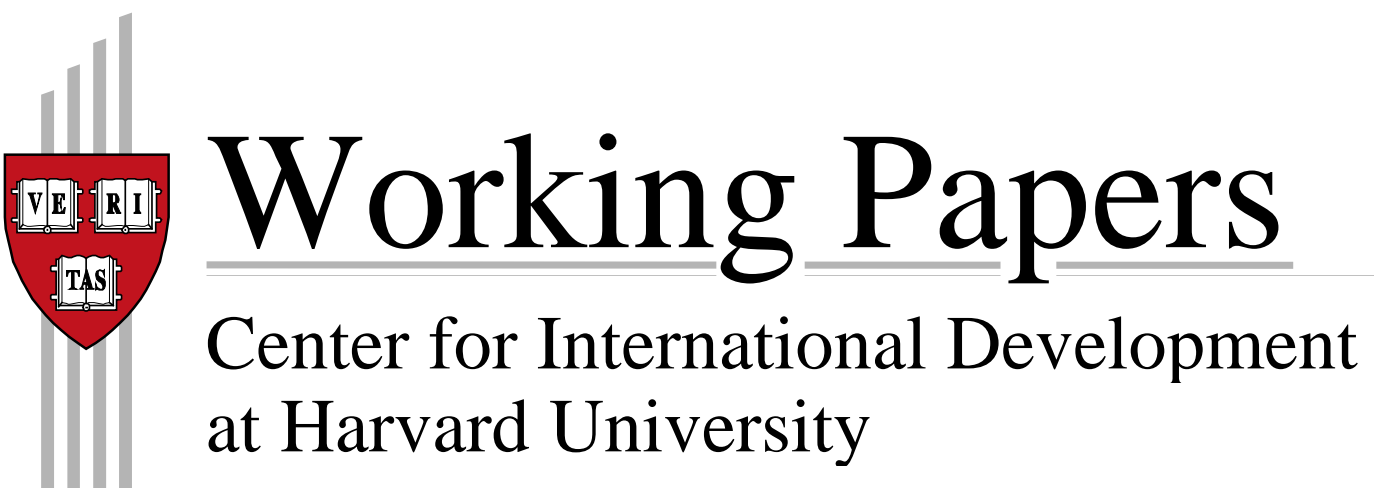




\title{
Development as Leadership-led Change
}

Matthew Andrews, Jesse McConnell, and Alison Wescott

October, 2010

\begin{abstract}
Development involves change, but many development initiatives produce unimpressive results. The authors ask why and consider how to close the gap between the intended change and what we actually see in the evidence. This paper presents the findings of a study, initiated by the multi-donor Global Leadership Initiative and led by the World Bank Institute (WBI), to examine leadership in the change processes of fourteen capacity development interventions in eight developing countries, through 140 in-depth structured interviews. It explores what it takes to make change happen and in particular, the role leadership plays in effecting change. The authors propose that leadership contributes to change when it builds "change space" by fostering acceptance for change, granting authority for change, introducing or freeing the abilities necessary to achieve change. This "change space" is required to ensure contextual readiness for change and foster progress through the difficult stages of the change process. An analytical framework is introduced to illustrate the dimensions of this "change space" and its limits in organizational and social change. The authors argue that a lack of "change space" in many development contexts may be overlooked, contributing to failure. The paper concludes that leadership manifests in different ways in different contexts, depending on the contextual readiness and factors that shape change and leadership opportunities; but the key characteristics of plurality, functionality, problem orientation and "change space" creation are likely to be common to all successful leadership-led change events.
\end{abstract}




\section{Development as Leadership-Led Change - A Report for the Global Leadership I nitiative and the World Bank I nstitute (WBI) Faculty Research Working Paper Series}

\section{Matt Andrews}

Harvard Kennedy School

Jesse McConnell

Reform Development Consulting

\section{Alison Wescott}

World Bank Institute

March 2010 RWP10-009

The views expressed in the HKS Faculty Research Working Paper Series are those of the author(s) and do not necessarily reflect those of the John F. Kennedy School of Government or of Harvard University. Faculty Research Working Papers have not undergone formal review and approval. Such papers are included in this series to elicit feedback and to encourage debate on important public policy challenges. Copyright belongs to the author(s). Papers may be downloaded for personal use only. 


\title{
Development as Leadership-led Change ${ }^{1}$
}

\author{
A Report for the Global Leadership Initiative ${ }^{2}$ and the World Bank Institute (WBI)
}

Matt Andrews $^{3}$, Jesse McConnell ${ }^{4}$ and Alison Wescott ${ }^{5}$

\footnotetext{
${ }^{1}$ The findings, interpretations, and conclusions expressed in this paper are entirely those of the authors. They do not necessarily represent the views of the International Bank for Reconstruction and Development / World Bank, or the World Bank Institute (WBI) and its affiliated organizations, those of the Executive Directors of the World Bank, the governments they represent or the members of the Global Leadership Initiative Working Group.

${ }^{2}$ This work was financially and logistically supported by the Global Leadership Initiative, a partnership composed of then World Bank Institute, U.K. Department for International Development, Canadian International Development Agency, UNDP, and the French Ministry of Foreign Affairs

${ }^{3}$ Assistant Professor of Public Policy, Harvard Kennedy School.

${ }^{4}$ Reform Development Consulting, Durban, South Africa.

${ }^{5}$ World Bank Institute.
} 


\section{Contents}

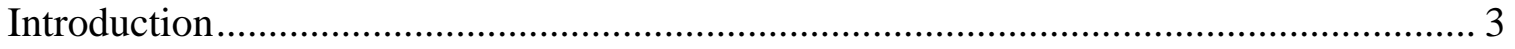

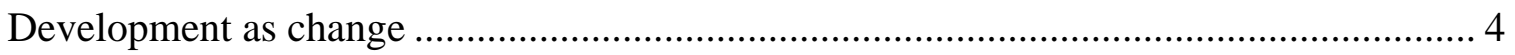

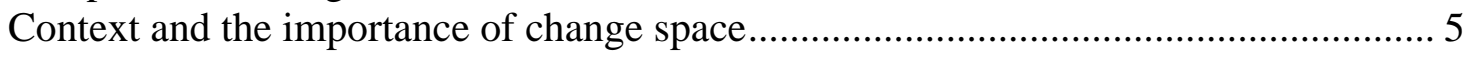

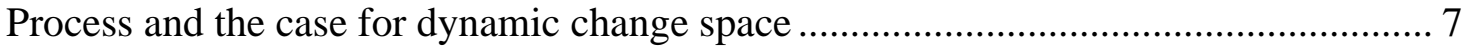

Content, the possibilities of problems, and contingency of change space.................... 9

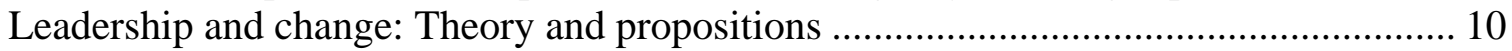

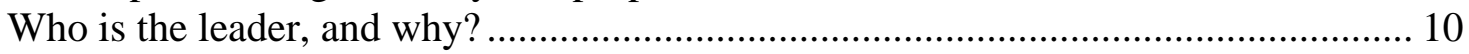

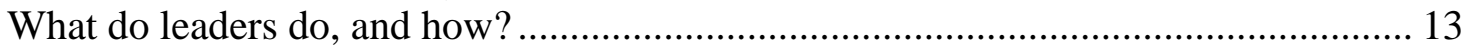

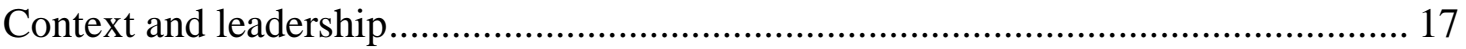

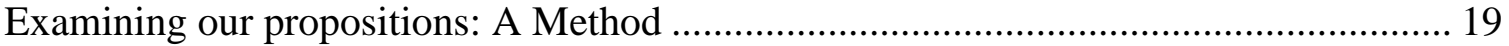

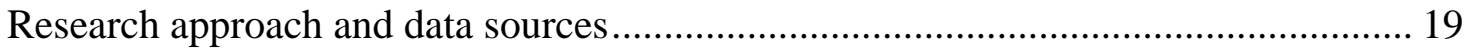

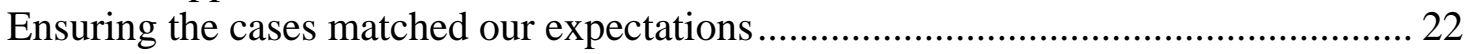

Examining leadership-led change propositions: Results and discussion......................... 26

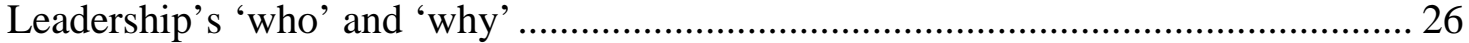

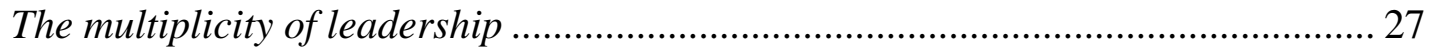

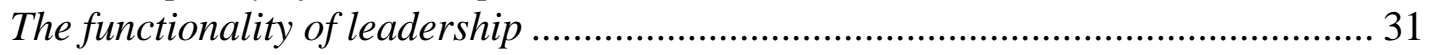

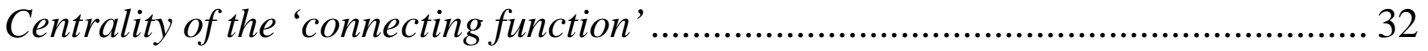

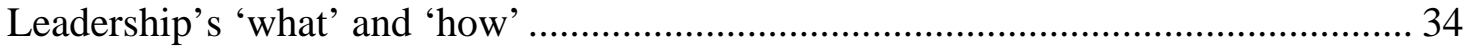

What and how leadership impacts on Acceptance .................................................. 35

What and how leadership impacts on Authority .................................................... 39

What and how leadership impacts on Ability ...................................................... 43

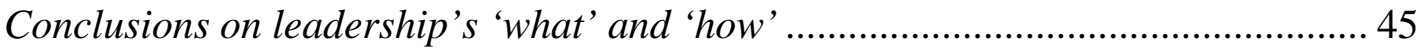

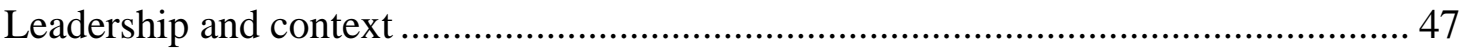

Conclusions, and a case for more leadership work in development .............................. 50

Annex 1. Five stages in the change process: A simple model ....................................... 52

Annex 2. 'Who' were identified as leaders (number of references in parantheses) ......... 54

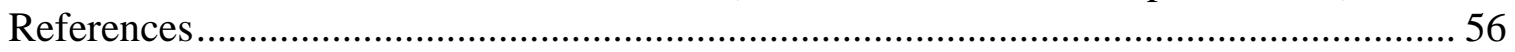




\section{Introduction}

Development involves change. But many development initiatives produce unimpressive levels of change in targeted countries, organizations and outcomes. This is the case in social sector initiatives, ${ }^{\mathrm{i}}$ core public management reforms, ${ }^{\mathrm{ii}}$ and even macroeconomic adjustment operations. ${ }^{\text {iii }}$ Change is often limited even when countries adopt proposed solutions in their proposed forms, in apparently good faith and on time (or in reasonable time). ${ }^{\text {iv }}$ We wonder why, and believe research should ask how to close the gap between the change intended in development (what is proposed) and the change we actually see in evidence. This research paper aims to (modestly) contribute to such research by exploring what it takes to get change done; and particularly what role leadership plays in effecting change.

The first section briefly discusses literature on change in large organizations and proposes a simple change space model for understanding change and its limits. The model posits that organizational and social change emerges when there is acceptance, authority (and accountability) and ability to allow and catalyze ongoing as well as episodic adjustments. This space is required to ensure contextual readiness for change and to foster progression through different stages of the change process.

Change space must fit the specific change content and, we argue, emerges more organically to ensure such fit when change content emerges through problem solving (instead of as solutions provided from the outside). The lack of change space in many development contexts often goes ignored, contributing to developmental failures: Projects and interventions generally call for more and different space than is available, do nothing to enhance or shape the space (depending rather on what Nutt (1986) calls "implementation by edicts" of pre-determined solutions) and fail as a result. Often, as Pritchett and Woolcock (2004) muse, these solutions become future problems.

The second section asks what role leadership plays in the change process (particularly in facilitating the creation of change space) given that there is an almost universal agreement that agents play an important part. The answer must go beyond "being a champion" and "providing political will"- - two common refrains used in development to reference leadership. In looking for an answer, we raise basic but key questions: Who is seen as the change leader? Why? What do leaders do to effect change? How? Tackling these questions with reference to literature, we posit some propositions about how leadership manifests and matters in the change process:

- Leadership is more about groups than individuals, given that there are likely to be multiple people exercising leadership in any successful change event.

- 'Leaders' are identified more because of their functional contribution to change than their personal traits or authority (and the 'connecting' function stands out).

- Leadership contributes to change when it builds change space-where leaders foster acceptance for change, grant authority to change (with accountability), and introduce or free the abilities necessary to achieve change. Change space is especially enhanced where leadership facilitates open access societies and learning organizations in which members are empowered - in groups - to pursue change through problem solving.

- Leadership manifests in different ways in different contexts, depending on contextual readiness and factors that shape change and leadership opportunities; but the key 
characteristics of plurality, functionality, problem orientation and change space creation are likely to be common to all successful leadership-led change events.

Section three introduces an empirical study we conducted to investigate these propositions in the development context. It begins by pointing out that some development interventions do already propose leadership-led change, introducing brief examples captured by the multi-donor Global Leadership Initiative (GLI). ${ }^{\vee}$ We examined what leadership looked like in the change processes of fourteen such interventions (in eight different developing countries) where we conducted over140 in-depth structured interviews as the primary source of data. We focus on fragile countries, coming out of conflict, facing tense government transitions, and so forth, because we see these as extreme cases where expressions of leadership-led change will stand out. Recent work (including Collier, 2007) argues that these countries are in a development trap, characterized by recurring conflict and tension and low growth; there is a dearth of leadership and leadership-led change that promotes shared growth and development.

Section four presents results from the selected case studies, and discusses these in relation to our theoretical propositions. Our analysis provides support for our propositions and the idea that leadership and leadership-led interventions can have an impact on change space and ultimately on change, even in these complex contexts. We conclude with recommendations for those in development, centered on the idea that development is about leadership-led change:

- Leadership is a key to effecting change and promoting development.

- Leadership interventions should focus on building functional groups of leaders-in teams, coalitions and networks—around unifying problems.

- Leadership interventions should always be focused on creating change space rather than creating leaders as an end.

- Leadership interventions must be fitted to context but consistently emphasize leadership plurality, functionality, problem orientation and change space creation.

\section{Development as change}

Development initiatives often disappoint in terms of final results. Interestingly, we find that organizational change frequently fails in the private sector as well. Gilley $(2005,4)$ cites various studies showing that one half to two-thirds of major corporate change initiatives (and 50 to 80 percent of reengineering efforts) are failures, ${ }^{\text {vi }}$ less than 40 percent of these produce positive change, and one third actually make the situation worse. Other studies find "initiative decay" in change processes, where gains from change are either never realized or lost because new practices or approaches are abandoned. ${ }^{\text {vi }}$ Basically, then, change is difficult everywhere, and answers about how to do change cannot be assumed as intuitive or well known. Especially when the goal is for substantive change where, "Not only have the process and outcome changed, but the thinking and attitudes behind them are fundamentally altered and the systems surrounding them are transformed in support” (NHS Modernization Agency 2002, 12)

The organizational change literature offers a ubiquitous set of ideas on why change often fails and how to do it better. ${ }^{\text {viii }}$ It is impossible to do the entire literature justice, but some lines of thought do recur across many studies and allow for fairly generalized application. 
In this section we build on dominant discussion lines (about change context, process and content $)^{\text {ix }}$ in proposing a model to think about achieving change and development. The next section asks how leadership engagements fit into such model.

\section{Context and the importance of change space}

Change seldom happens in a void or against a clean slate where all options are on the table and possible to adopt. There is always a set of contextual issues to consider, manifest in an entity's external and internal environment. Some call this the political economy context; ${ }^{\mathrm{X}}$ others refer to the historical or institutional setting. ${ }^{\mathrm{xi}}$ Kurt Lewin (1951) described a 'force field' of driving and limiting factors in which organizations operate. Change requirements arise in this force field but change is also limited by it. We discuss both aspects of contextual influence: on what change is needed and the challenge of effecting change.

While most theorists agree that change opportunities (or needs) emerge because of some tension in the organizational context, ${ }^{\text {xii }}$ there is disagreement about how and how regularly this happens and what challenges are created for effecting successful change:xiii

- Some hold that organizations tend to settle into semi-permanent equilibriums facilitated by well balanced, stabilizing internal and external factors. Shocks periodically destabilize the equilibrium, threatening the organization's survival and requiring it to adjust. Organizations resist internal change even in the face of disturbance, however, and such contextual inertia demands corrective interventionthe basis of episodic change.

- Some present change differently, however, as continuous, “ongoing, evolving and cumulative” along historical paths of constantly shifting equilibriums that makes stability a dynamic challenge (Weick and Quinn 1999, 375, 379). Change in this approach involves constant "accommodations, adaptations, and alterations" which lead to fundamental evolution over time (Orlikowski 1996, 66). The challenge is to constantly redirect what is already in place to ensure long-run adaptability to context-rather than effecting major episodic adaptations to shocks.

We believe that change actually has elements of both episodic and continuous models, ${ }^{\text {xiv }}$ and that the common challenge is to identify (and create) the capacity for organizational and social change given contextual pressures (episodic and ongoing). We refer to this as change space which we liken to the idea of an organism's fitness to adapt to evolutionary challenges. Just as a biological organism's adaptive ability depends on its genetic makeup, we hold that organizational and social capacity to change depends on the space to identify change, shift focus towards change demands, and embrace new forms and functions that aid progress and development. Organizations and systems with limited change space lack the wherewithal to manage contextual adjustment and fail to change; just as low fitness organisms fail to evolve and ultimately perish. ${ }^{\mathrm{xv}}$

There are various antecedents to the idea that the contextual space in which change happens matters - and that active engagement is required to understand this space and to (sometimes) engineer extra space for change. Related work reflects on the importance of space in organizational ${ }^{\mathrm{xvi}}$ and social and economic system ${ }^{\mathrm{xvii}}$ change and we (perhaps uncomfortably) speak interchangeably of both in this paper-primarily because we feel development challenges occur in both and our arguments have dual application. Drawing 
from the literature ${ }^{\text {xviii }}$ and building on our own prior thinking, Figure 1 illustrates a basic change space model incorporating three factors we see as centrally influencing organizational and social capacities to adjust to contextual demands: Acceptance, Authority (and accountability) and Ability (Andrews 2004, 2008b).

Figure 1. The AAA model of change space

No change space exists because the AAA's are all deficient and/or non-convergent

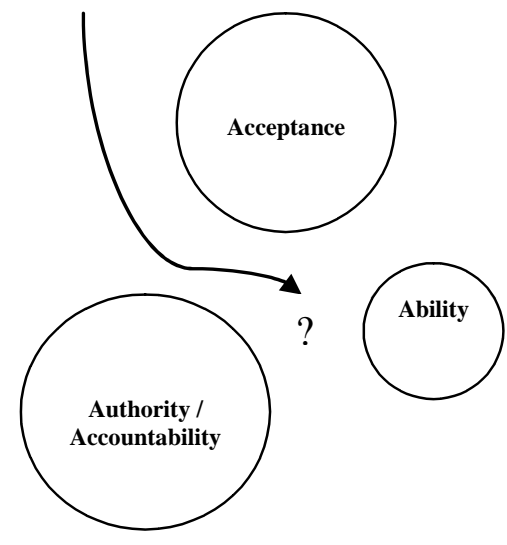

Some change space exists because the AAA's are all sufficient in size and converge

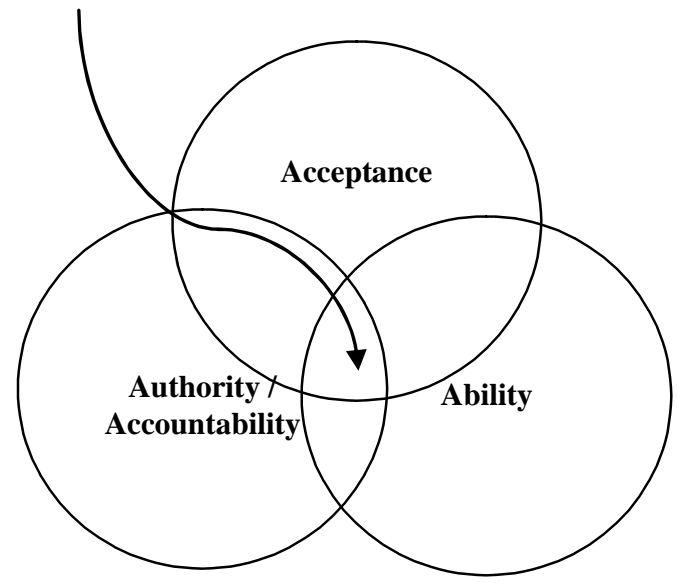

Source: Adapted from Andrews (2004, 2008b).

By acceptance we combine what others variously term 'mindset', 'political will', 'buyin', 'ownership' etc. in regard to the beliefs agents have about change (as in, "I accept we need change") and formal commitments to change (as in legal acceptance of a contract). ${ }^{\text {xix }}$ Change requires acceptance (a belief-based commitment) by affected agents in the change context, of various change aspects. Change also requires appropriate authority and accountability structures that influence whether and how agents develop and act on change beliefs, commitments and needs. These structures constitute key contextual influences on the change space, and have both formal and informal manifestations (laws and codes and norms of appropriateness, social conventions and the like). ${ }^{\mathrm{xx}}$ Change space is also influenced by the ability profile of a particular organization or society. Change generally requires abilities or resources and a context may be constrained by the amount of fiscal, human and/or informational abilities available, or by the degree to which latent resources are given free expression in exploring, pursuing and implementing change.

Figure 1 shows that change space emerges at the intersection of these three factors, where there is some congruency in Acceptance, Authority (and accountability) and Ability, catalyzing and allowing change. ${ }^{\mathrm{xxi}}$ The change space might not exist in some contextsfundamentally prohibiting change; or it might be limited-allowing only peripheral change across an organization or system or change in only one part of the system; or it might be substantial-accommodating a response to contextual challenges that allows full organizational adaptation. Given such thinking, we believe that the change space 
model helps one think about contextual challenges of both episodic and continuous change approaches as well as contextual limits common to development:

- Organizational inertia is often identified in contexts where we see weak acceptance of a change need and entrenched authority structures, for example, while continuous adaptation to environmental pressure is constrained where organizations do not accept the need or authorize activities to consistently scan the environment and test norms. ${ }^{\text {xii }}$

- Narrow political elites in developing countries often adapt better to shocks and through episodic change than the general citizenry because elites control political authorizing structures (often over key ability factors) and hence enjoy more change space to pursue policies and solutions that serve their accepted interests. ${ }^{\text {xxiii }}$

- In contrast, the context of more developed open access societies generally allows greater change space, ongoing and episodic, where more agents have authority, access and freedom to express ability, and a holding space to learn and build acceptance. In our model, this expanded space facilitates more successful adaptation over time for larger portions of the population. ${ }^{\text {xxiv }}$ Figure 2 illustrates this kind of society in the 'large change space' for change, contrasted with more limited change space contexts.

Figure 2. Contextual change demands, contextual change space, and results

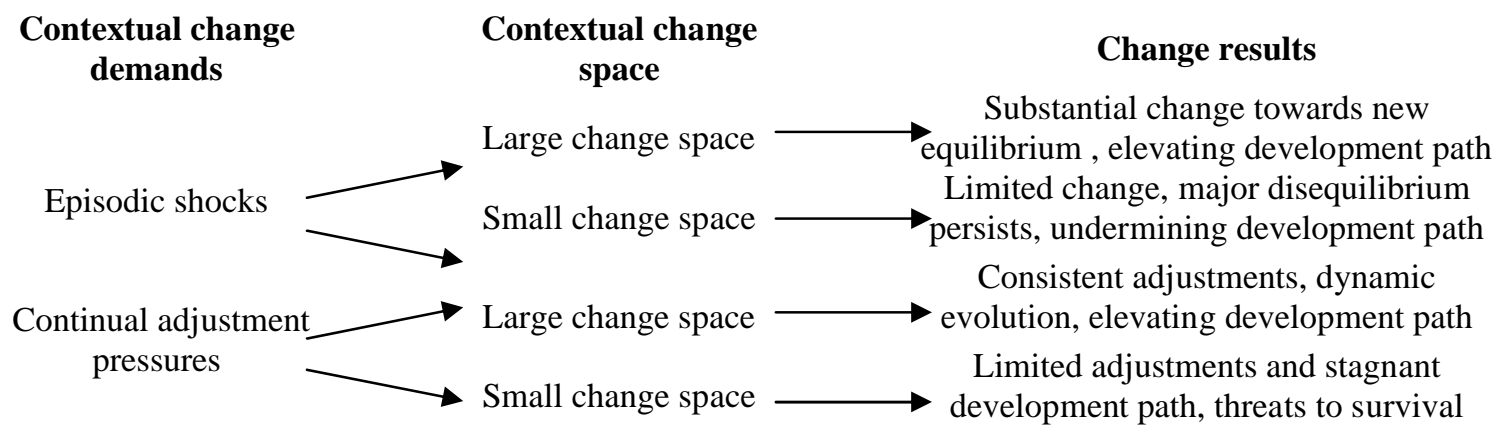

\section{Process and the case for dynamic change space}

Space does not have a static importance, but emerges as important in a process where different stages have different space requirements. The process idea dates back to Lewin's (1947) three stage model emphasizing first unfreezing the inertial equilibrium then moving to a new way of doing things and ultimately freezing the change in a new equilibrium. We build on Lewin's model, our previous work (Andrews 2008), and that of others $^{\mathrm{xxv}}$ to suggest a five stage process in Figure 3 (given more detail in Annex 1) where:

- Pre-conceptualization involves establishing readiness and acceptance for change

- Conceptualization involves establishing a change vision and plan

- Initiation sees change agents instigating change through early adoption mechanisms

- Transition involves the spread of change as it starts to replace old ideas and processes

- Institutionalization is where change becomes widespread de facto reality. 
Figure 3. Simplified stages of psychological and learning journeys for change targets

\begin{tabular}{|c|c|c|c|c|c|c|c|}
\hline Change stages & Pre-conceptualization & \multicolumn{2}{|c|}{ Conceptualization } & Initiation & Trans & & Institutionalization \\
\hline $\begin{array}{l}\text { Psychological } \\
\text { issues }\end{array}$ & \multicolumn{2}{|c|}{ Skepticism/Cynicism/Denial/Resistance } & \multicolumn{3}{|c|}{ Exploration } & & Commitment \\
\hline $\begin{array}{l}\text { (and strategic } \\
\text { responses) }\end{array}$ & \multicolumn{2}{|c|}{ (Anticipation/Confirmation) } & \multicolumn{3}{|c|}{ (Culmination) } & & (Aftermath) \\
\hline $\begin{array}{l}\text { Learning } \\
\text { dimensions }\end{array}$ & \multicolumn{2}{|c|}{ Unlearning and frame braking } & \multicolumn{3}{|c|}{ Cognitive re-definition } & & $\begin{array}{l}\text { rsonal and relational } \\
\text { refreezing }\end{array}$ \\
\hline
\end{tabular}

Source: Adapted from Andrews (2008b, 101) and Armenakis and Bedeian (1999).

Figure 3 also incorporates ideas of change journeys from social psychology and organizational learning literatures. These journeys are increasingly emphasized in the literature on change, ${ }^{\mathrm{xxv}}$ with Judge et al. $(1999,107)$ arguing that change success may lie "within the psychological predispositions of individuals experiencing the change." In their summary of the human side of change, Ellrod and Tippett (2002) find many articles employing a sequential process of learning and emotional engagement akin to Lewin's three stage model. ${ }^{\text {xxvii }}$ Figure 3 draws on these articles to show that change targets move from skepticism to commitment by passing through specific stages in which they exhibit strategic behavioral responses (like anticipation, confirmation, culmination and aftermath (Isabella 1990, described in Annex 1)). This psychological journey is facilitated by a similar learning process that involves initial frame breaking, cognitive re-definition and personal and relational refreezing. Change targets need to be provided "psychological safety" in this process and encouraged to question both their organizational strategies and underling norms and values (as in double-loop learning by Chris Argyris (1990)).

An effective, change facilitating journey is characterized by learning induced trust, empowerment of change targets and acceptance of the change experience by these targets. We note that this journey requires specific space, where enough people believe learning matters and are committed to the journey, they are authorized (and given safety) to learn, and enabled in the process. Heifetz, Linsky and Grashow's $(2009,155)$ "holding environment" conceptualizes such space, which provides "safety and structure for people to surface and discuss the particular values, perspectives, and creative ideas they have on the challenging situation they all face.” This space, the authors argue, is vital for "doing adaptive work in organizations.”

Figure 3 seems to suggest that the change process is linear but we agree with most theorists and practitioners that this is seldom the case. ${ }^{\text {xviii }}$ We copy Buchanan, et al. (2005, 199) in citing Pettigrew's belief that change is an "untidy cocktail” that is neither "static [n]or neatly time bound" and believe that change involves complex iterative steps, feedback loops, and so forth that differ between contexts (and thus defy standard graphical representation in Figure 3). Acknowledging such complexity does not undermine the value in thinking about change processes, however. ${ }^{\text {xxix }}$ Empirical studies like Zand and Sorrenson (1975) and Ford and Greer (2006) find some support for the idea that change only reaches institutionalization successfully if it passes (at some point and in 
some sequence) through specific stages. Kotter $(1995,66)$ warns that bypassing certain stages is a "key error" (especially when "declaring victory too soon" or progressing to implementation before ensuring a need to change). ${ }^{\mathrm{xxx}}$

We think that it is useful to be aware of the different stages presented above, because we believe that the change space required in different stages is different. In early change stages the major challenge may be to facilitate contextual acceptance while in later stages it might be to introduce new abilities or formal and informal authorization mechanisms to institutionalize the change, for example. (Different challenges are described further in Andrews, 2008b). We believe that the different challenges of different stages are important building blocks of change (even if there are questions about which stage goes first) and imply different challenges and the need for different strategies as change progresses. We believe it is useful to ask, especially in the development context, whether: Enough time is spent on creating readiness for change in pre-conceptualization?; The psychological journey gets any attention in technical reform?; Attempts are made to foster the learning journeys that theory suggests are vital to getting people to move?

\section{Content, the possibilities of problems, and contingency of change space}

Literature reminds us to remember content when we consider the space needed to effect change and the contextual and process demands of change. Space and process (how to do change) are ultimately contingent in some respect on content (what the change is).

Content refers to the change being implemented and is peculiar to the specific change event. Differences in content accommodate different types and degrees of change and require different change strategies. Many authors emphasize the importance of problems as the basis of content, for example, and argue that the failure to frame change as the result of and response to an emerging problem significantly limits the potential to effect change. ${ }^{\text {xxi }}$ A problem (or even better a crisis) forms the basis of ensuring a need for change and framing a vision that is appealing to change targets (vital in obtaining acceptance for change).

Problems come in different forms, which have captured the attention of various authors. Contingency theorists note that some problems emerge from profound uncertainty and have no known solutions, for example, while others are better understood and the set of solutions is more apparent. These different problems demand different types of change space. Countries trying to identify new industries to drive growth require large, experimental change space while countries trying to better regulate an existing industry require more structured and specified space, for example.

Burke and Litwin (1982) identified other differences in problem types, calling some transformational and others transactional. Transformational problems require change to the core values and behaviors of organizations and individuals, whereas transactional problems involve adjusting the structural parameters that determine an organization's incentives, motivation and control infrastructure. Transformational problems require adjustments to core factors like mission, culture and strategy while transactional problems entail a different content altogether (management practices, structures, policies and procedures). ${ }^{\text {xxii }}$ Heifetz (1994) and Linsky and Heifetz (2002) refer to similar content differences when they differentiate between adaptive and technical problems. Technical problems can be addressed by a technician or expert who fine tunes existing 
ways of getting things done, while adaptive problems require deeper transformation by more people in the community who have to change their values, behavior, or attitudes; often learning new ways of doing new business. Linsky and Heifetz (2002) argue that many change initiatives fail because adaptive problems are misdiagnosed (and/or mistreated) as technical problems - with incorrect change space provided and often poorly fitted processes followed.

The argument is relevant, we believe, for the development community; where problems are generally adaptive and solutions are commonly technical. Change is limited because adaptive problems are different to technical problems-requiring different change space and different change process.

\section{Leadership and change: Theory and propositions}

This discussion showcases the complexity of change and raises a question: Who ensures that change context, process and content relate effectively and that change space is engineered to ensure readiness for change and adjustment in the change process? While some disagree, ${ }^{\text {xxxiii }}$ most theorists would answer, "That is the role of leadership!"xxxiv Many leadership scholars connect leadership to change as well, including Burns (1978) who argues that leadership manifests most in the change context, and Linsky and Heifetz (2002) who introduce leadership as facilitating adaptive change. Yukl (2002, 273) argues that, "[Change] is the essence of leadership and everything else is secondary."

The leadership literature comprises a fragmented set of perspectives balkanized into “various clusters of theories and approaches" (Fernandez 2004, 200). Theorists relate steadfastly to schools of thought that seem exclusive and difficult to integrate, sporting names like "trait theory", the "leadership behavior" school, "power and influence approach", "situational and contingency theory", "transactional and transformational leadership”, “collaborative leadership”, “connective leadership” and "followership”. These schools tend to posit different arguments in regard to fundamental questions, like: Who is the change leader? Why? What does the leader do in the change process? How? How does context influence leadership in change?

We believe these are vital questions to better understand how leadership makes a difference in the change process. They are also important for those parties attempting to craft interventions that stimulate leadership-led change solutions. We address them below and raise research propositions based on our attempt at an inclusive reading of the literature, and the change space perspective already discussed.

\section{Who is the leader, and why?}

Modern leadership literature arguably has its deepest roots in writings about individual leaders and the nineteenth century's great man theory. This approach is said to underlie trait theory which suggests that peculiarly talented individuals (mostly men) are called 'leaders' because of a set of personal characteristics that sets them apart from others. Carlyle's work (1841) identifies specific talents, skills and physical characteristics of men who rose to power, and a variety of studies have followed suit. ${ }^{\mathrm{xxv}}$ Commonly touted traits see leaders as honest, forward-looking, competent, inspiring and intelligent. Many other traits are identified across studies, however, undermining the theory’s consistency, 
and numerous studies attempting to link traits and change effectiveness have produced weak results, calling the theory further into question (Bass 1990). Negative experiences with 'Big Men' in development have also weakened the theory's attractiveness.

Weber's (1948) charismatic leader reflects a version of trait theory ${ }^{\mathrm{xx} x \mathrm{i}}$ but is only one of three leadership profiles he identified. Two other types reference legal and social authority structures as influences on who leads and why. The rational-legal leader is an individual who has been given the power to issue commands and exercise authority by virtue of legal rules and often because of his (again a male bias) superior knowledge. These leaders face strict, systematic discipline under the law and typically lead within a hierarchy and given a specific position. The traditional leader enjoys authority passed down by tradition (in the case of royalty for example), relationship or favoritism (in the case of politics). These leaders often exercise arbitrary power and are disciplined only by traditions and relational or power structures that might control their power.

There are other theorists who argue that traits and/or authority are not what define leaders from others. Some, like Linsky and Heifetz (2002) are reluctant to speak of leaders at all, and couch leadership in terms of actions (by anyone) that help a set of people overcome adaptive challenges. They argue that people in authority and with attractive traits often do not use their authority or supposed talents to facilitate change (hence not exhibiting leadership). Their approach resonates with functional leadership theory, purported by authors like Hackman and Walton (1986) and Zaccaro at al. (2001). This approach concentrates on how leadership occurs, rather than who does the leading. Different scholars cluster leadership functions differently, but common approaches emphasize substantive contributions to task (like providing ideas or information), procedural contributions that aid groups to address tasks (like facilitating discussion, providing appropriate authorizing mechanisms and relational structures) and maintenance contributions (that allow relationships to develop and grow through provision of holding environments). It is important to note that leadership is most commonly seen as a distributed function across social structures (like teams, coalitions and networks) in this approach: And people at all levels and in all parts of the structure can participate, providing leadership in functional ways at appropriate times of need and opportunity.

We are attracted to this kind of approach, which emphasizes the functional contributions leaders bring to change and not their positions or traits. We believe it is potentially inclusive of the other approaches - with talented and authorized individuals capable of playing functional roles as well (where their leadership contribution centers on how they use their talents and authority). We also believe there is sense to the idea that leadership generally involves multiple parties rather than lone individuals. This sense emerges in the simple idea that multiple functions are required to effect change through multiple stages, requiring multiple parties to provide leadership. Studies suggest this is the case:

- Rimmer et al. $(1996,43)$ shows, for example, that change in Australian firms is often catalyzed by the CEO but also depends on "a more complex and pluralistic process involving different stakeholders.” Different leaders play different roles (with the CEO providing vision and support, middle managers operationalizing plans, external consultants providing outside knowledge and union leaders "open[ing] the doors to workforce involvement and the development of trust”). 
- Himelein and Andrews (forthcoming) illustrate (in Figure 4) how the industrial promotion agency CINDE engaged with multiple parties to facilitate industrial change in Costa Rica, helping the country move from exporting bananas to microchips in a relatively short period. The change came largely because of the leadership networks that had been building since the 1970s which Himelein and Andrews show in a simplified schema along the lines of Pemberton's (2000) policy networks. The central box represents a 'policy making terrain' where actors were connected from four groupings; political and government, private sector, international and issue actors (academia, advocacy, etc.). Parties in these four groups acted together (within the broader environmental context), providing the leadership required to advance the country's economic growth.

Figure 4. A policy network approach to looking at CINDE's Costa Rican influence

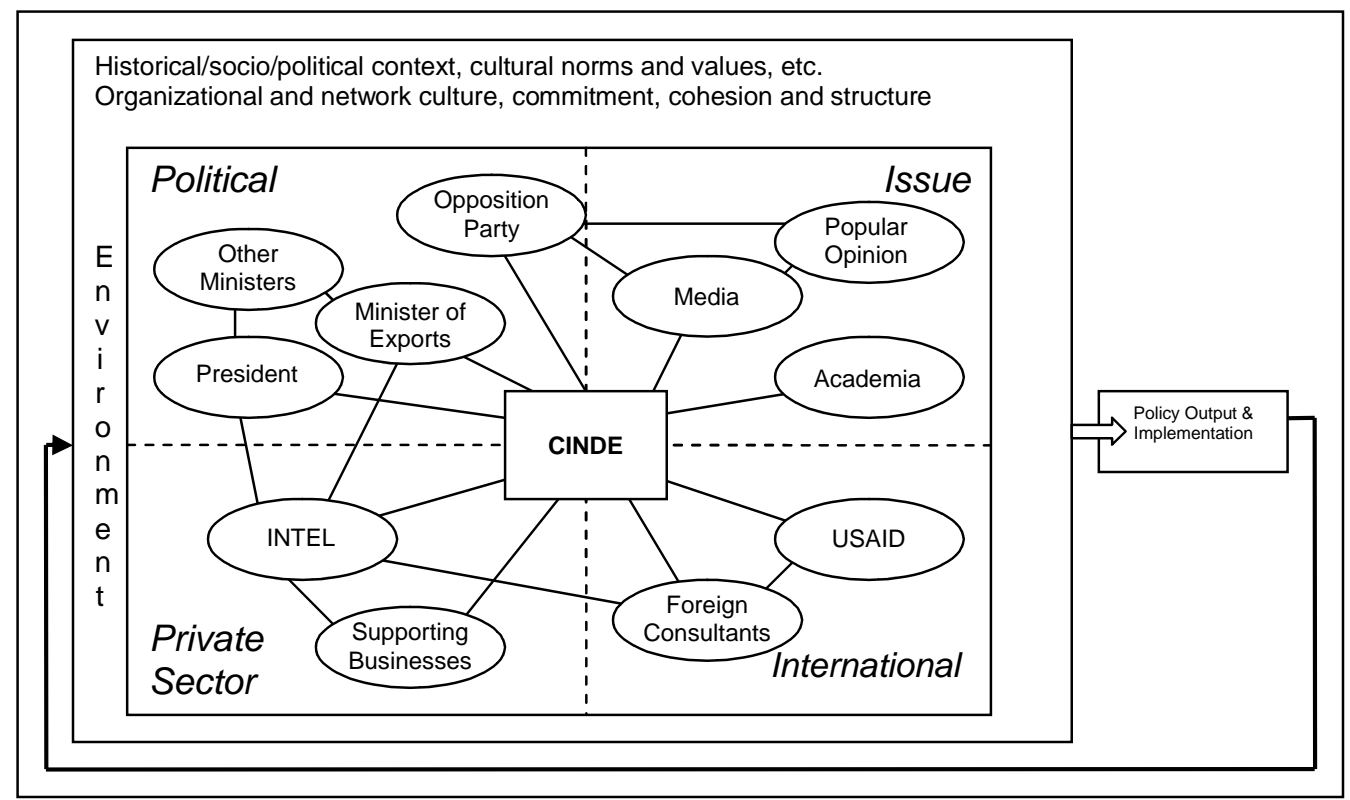

Source: Himelein and Andrews (forthcoming)

Other studies similarly tout a plurality of roles in change processes like the "idea champion" who leads and maintains commitment to a change idea (Kanter 1983) and the "fixer" who coordinates the behavior of disparate actors to overcome change obstacles (Bardach 1977; O’Toole 1989). Figure 5 shows a basic network with some such roles identified and a "fixer”, “connector", or "coordinator" at its center. This role has emerged as a vital leadership function in theories ranging from collaborative leadership (Kanter 1994) to connective leadership (Lipman-Blumen 2000) and leadership in networks (Andrews 2008; Balkundi and Kilduff 2006). This role player connects the multiple leaders to each other, facilitates coordination amongst them so that their functional roles are demanded and supplied and engaged when necessary and in the right combinations. We see CINDE playing this role in the Costa Rican example (Figure 4). Acknowledging this role in context of a functional approach to leadership in groups, we offer the following research propositions: 
- Leadership is more about groups than individuals, given that there are likely to be multiple people exercising leadership in any successful change context

- 'Leaders' are identified more because of their functional contribution to change than their personal traits or authority; the 'connecting' function stands out as vital.

\section{Figure 5. A simple, function driven leadership network}

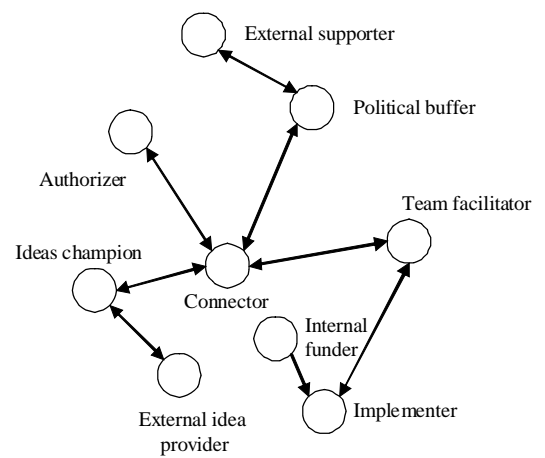

While not a formal research proposition, we observe from the literature (and examples cited above) that leadership is not always exercised through people alone but also involves organizations and other social groupings. Ogbonnia (2007) finds leadership exercised through political parties, for example, Rimmer (cited above) notes the leadership role played by unions, and the Costa Rican case notes an important role for CINDE-a multi-organizational entity. In all cases the focus of leadership is not on who but on why, and what their functional contribution is to change.

\section{What do leaders do, and how?}

Combining this functionally driven approach to leadership with the change space model introduced earlier allows us to suggest a simple answer to the question(s), "What does the leader do in the change process?” and "How?" Given our expectation of leader plurality we choose to speak of leadership instead of leaders, which we believe involves the set of actions that intentionally creates change space and mobilizes people, ideas, meaning and resources to achieve a change purpose. We present this idea in Figure 6 which shows that leadership actions center particularly on enhancing the acceptance of change (by expanding from the smaller to the bigger circle through encouragement of changeoriented beliefs and commitment) as well as the authority and abilities agents need to explore and pursue change in any given context. The ultimate aim is expanded change space at the center of the figure and expanded change emerging in this space. Leadership actions could expand space at the start of the change process or during any stage leading to institutionalization, and are actually required at all stages to effect institutionalization. 


\section{Figure 6. What leadership does in the change process $=$ Creates change space}

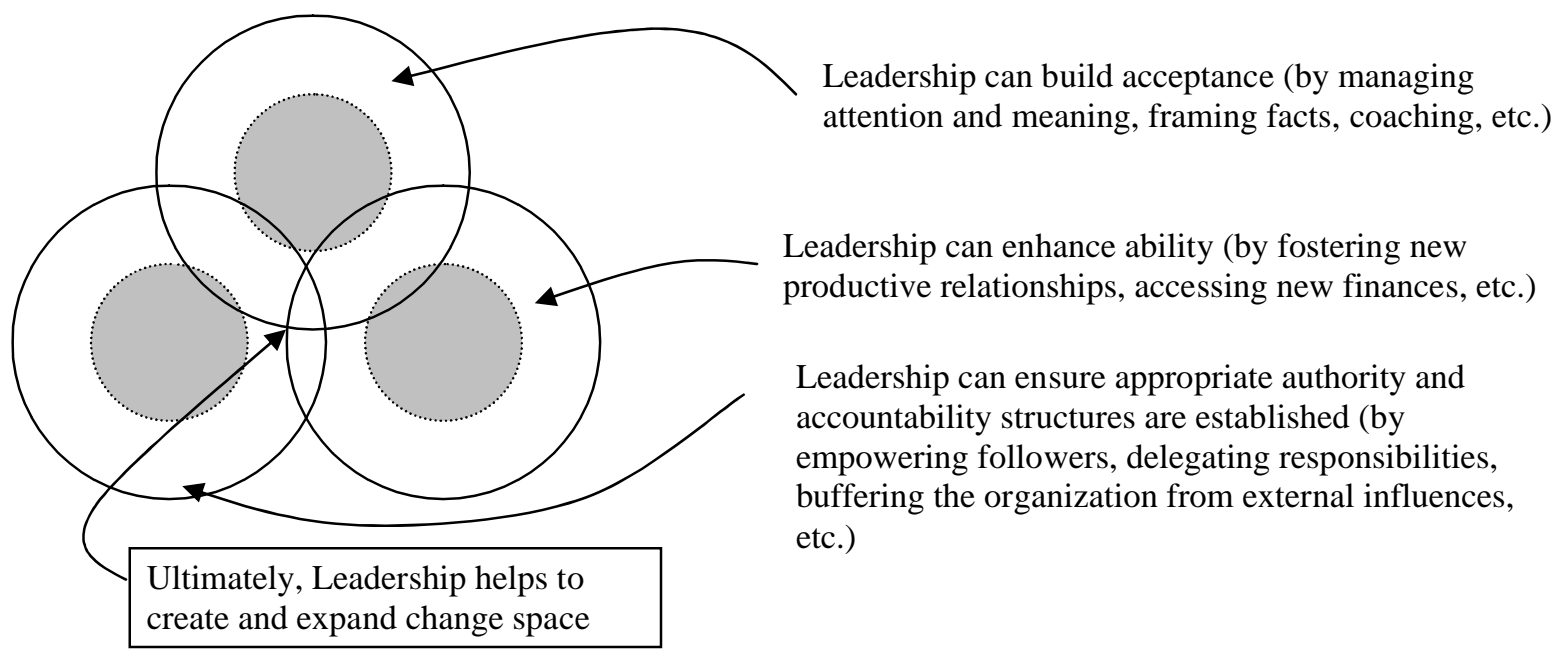

Source: Based on Andrews (2008b).

We believe this approach to understanding what leadership does (and how it does this) in the change process is broadly inclusive of many different theories about the topic. Three types of theoretical approaches are particularly useful in organizing our 'what' and 'how' ideas: transformational, transactional and relational leadership models (where the last refers to connective, collaborative and network theories in particular).

Transformational leadership (Burns 1978) manifests when leaders motivate people in their organizations and societies to aspire towards some higher purpose or better condition of the group they relate to. These leaders focus agents on new purposes through persuasion and reference to vision, building belief in and commitment to something 'better' (facilitating acceptance) and inspiring confidence, responsibility and even capacity to pursue this 'better' state (enhancing authority and ability). Bass (1998) argues that such leaders may be charismatic but also need to know how to provide "intellectual stimulation" and "individualized consideration" to followers. ${ }^{\text {xxvii }}$ Similarly, Bennis (1993, 75-85) identified "four competencies of leadership" as an applied extension of 'how' transformational leadership works. As referenced in Hennessey (1998, 527), these include managing attention (introducing or catalyzing a new vision in an organization), managing meaning (communicating the vision, including through behavior modeling), managing trust (by demonstrating reliability and constancy), and managing self (which interestingly involves knowing when and how to delegate and engage others in the change process). Hennessey $(1998,527)$ argues that "each of these four competencies directly addresses what the leader does" and finds that public sector reinvention (in the US government) is catalyzed when they are present.

We believe that transformational leadership fosters reinvention because motivational actions can expand the space agents have to explore and implement change-being more inspired, committed and empowered to adjust. Leadership can also involve actions that are less 'inspirational' in nature, however. Burns (1978) refers to transactional leadership where delegated authority and incentive and control mechanisms are used to 'lead' an 
organization in accomplishing a goal-which often involves change albeit motivated by the personal interests of agents (rather than their more noble aspirations). Nye $(2008,63)$ says that these leaders "create concrete incentives to influence followers' efforts and set out rules that relate work to rewards." This type of leadership often involves actors in formal positions of authority and political leadership, where we see politics centered on the "acquisition, influence and exercise of authority" (Ilchman and Uphoff 1997, xxiii). These actors can foster change space by structuring rules, processes and incentives to encourage learning, experimentation, and delegated accountability to identify problems and pursue change as solution. They are particularly important in organizations and societies where institutions encourage behavior that does not contribute to development-involving shared growth and progress.

Some observers view transactional leadership as the poorer version of transformational leadership, noting that the latter has a more noble or moral drive. We disagree and argue that both sets of leadership activities can have a strong moral basis, facilitating change that furthers the production of public value and broadly empowers social agents (Moore 1991). Transformational leadership can stimulate this type of change but so can transactional leadership, especially through the creation of rules and incentives that incentivize agents to pursue public value creation, allow open access in societies and encourage learning in organizations (North 1995; Senge et al. 1999). Agents will not be able to respond to a transformational leader's inducement to transcend self interest and pursue core change if the society is closed and the organizational rules limit learning and discovery, for example, or where formal and informal institutions promote the pursuit of private rather than public value. Where transactional leaders foster societies that are open and focused on public value creation, and where learning is accommodated by progressive authorizing mechanisms, we believe agents have space to explore new beliefs, pursue good struggles, ${ }^{\text {xxviii }}$ experiment with latent abilities, and ultimately generate change that benefits others (even if there is no transformational leader appealing to higher ideals).

Beyond transformational and transactional leadership theory, we think relational leadership dimensions are vital to consider when asking what leaders do to create change space and how. In earlier discussion we argued that leadership is likely to involve more than one party: We believe that the social structures in which these many parties engage to get things done are key to understanding leadership in change. Structural examples include teams, coalitions and networks that emerge as vehicles through which leadership solutions facilitate change. Within these structures, and in different contexts, one finds different leadership actions facilitating relational connections and overcoming engagement problems centered on issues like communication, coordination, conflict and feedback. Relationship promotion can directly empower people and create change space. In rapid results initiatives, for example, the creation of teams is vital to getting people thinking about problems, finding creative solutions they can commonly believe in and commit to. Matta and Ashkenas $(2003,5)$ say that when leadership creates a team and assigns it authority to solve a problem and produce a result "the team is free-indeed, compelled - to find out what activities will be needed and how those activities will fit together." Obviously this is not always the case with teams and other social and participative structures, and the transactional designs of these matter a great deal. 
In referencing such designs, Archer and Cameron (2008) emphasize leadership roles in fostering collaborative relationships, simplifying complex situations for their people, and facilitating relationship building in their organization and between their organization and others. Linsky and Heifetz (2002) identify key relation-enhancing leadership acts including setting conflicts in dialog, creating holding environments for productive dialog in organizational and social settings, and delegating responsibilities. Heifetz, Linsky and Grashow $(2009,155)$ describe the holding environment in relational terms, consisting of,

"All those ties that bind people together and enable them to maintain their collective focus on what they are trying to do. All the human sources of cohesion that offset the forces of division and dissolution provide a sort of containing vessel in which work can be done.”

Gilley et al. (2008) include coaching and team building as examples of relational mechanisms leaders use to create such an environment and 'implement change and drive innovation'. Hudson (1990) also emphasizes coaching as a key leadership 'how', arguing that coaching empowers social relations, helping groups "to question the status quo, approach situations from a new perspective and allow others to make mistakes and learn from them.” Through such actions leadership empowers the social engagement of agents and 'unleashes change' (Kelman 2005) as the social structures become venues for building acceptance (common beliefs and dependence-based commitment), expanding group-based authority (with accountability) and connecting often-dispersed abilities.

Speaking of transformational, transactional and relational dimensions of leadership interventions requires us to mention the role of problems (again). We are struck by the regularity with which literature on leadership mentions the opportunities problems and crisis create for leadership. Problems are seen as vital to informing a change message (in a transformational sense), directing the way institutions and structures should be shaped to allow learning and pursuit of change (transactional actions), and creating a sense of urgency as the glue around which coalitions develop (relational actions), for example. Given the importance of problems, we believe that leadership action should center on unearthing and addressing problems. Schein $(1996,65)$ puts it nicely when he identifies problems as the starting point of any change - and we extend to leadership-engagement: "Only when one has genuinely understood the problem and what kind of help is needed, can one even begin..." Given this discussion, we offer the following research proposition about 'what' leaders do to facilitate change and 'how':

- Leadership contributes to change when it builds change space-where leaders foster acceptance for change, grant authority to change (with accountability), and introduce or free the abilities necessary to achieve change. Change space is especially enhanced where leadership facilitates open access societies and learning organizations in which members are empowered - in groups - to pursue change through problem solving.

We believe that an interesting extension of this proposition involves thinking of the interactive relationship between leadership and change space. Our core proposal sees leadership fostering change space but we also believe that change space creates opportunities for leadership, especially when the change space unearths problems and facilitates solutions to these problems (as in Figure 7). 
Figure 7. Is there a dynamic interaction between leadership and change space?

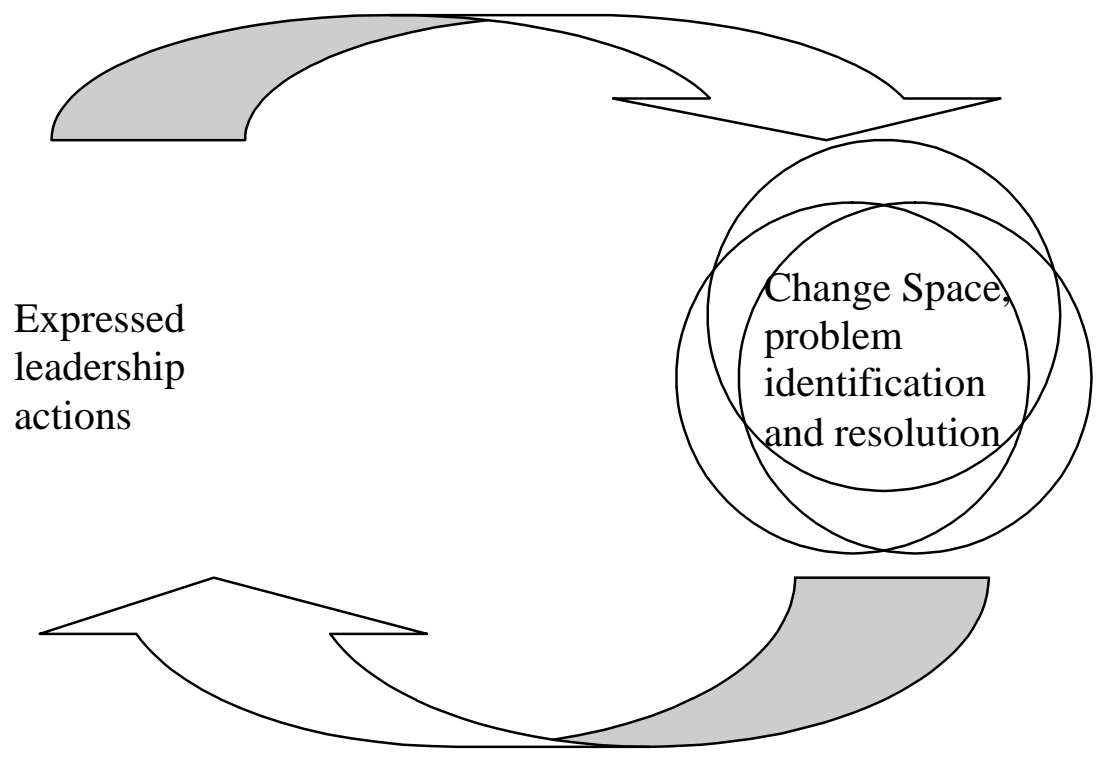

While beyond the scope of this paper, we wonder whether development in societies and organizations is a function of the persistence and regularity of such interaction? Are more developed nations characterized by situations where leadership creates change space and change through problem solving, which fosters new expressions of leadership in broader groups, which then facilitates more change space? Is this interactive dynamic the reason why some organizations and societies develop better abilities to identify and deal with problems, continuously and episodically, and improve their capacities? Are less developed countries and stagnant organizations characterized by limited leadership engagement fostering limited space and not then feeding dynamically into expanded forms of leadership and space? ${ }^{\text {xxix }}$

\section{Context and leadership}

We offer this and other propositions as particular ideas about what leadership that facilitates change looks like. We call this leadership-led change. Some may argue that the propositions are not suited to all contexts and are particularly unsuited to the context in which development occurs-involving hierarchical public organizations in developing countries. We disagree with this sentiment and believe that the propositions above hold for all contexts as core principles that hold even if the expression of leadership engagements probably differs somewhat. We thus offer a final proposition:

- Leadership manifests in different ways in different contexts, depending on contextual readiness and factors that shape change and leadership opportunities; but the key characteristics of plurality, functionality, problem orientation and change space creation are likely to be common to all successful leadership-led change events.

We do not deny that context influences leadership. Cross cultural work shows that culture influences the way people answer basic questions about leadership, for example, including "who" and "why": ${ }^{x l}$ Some cultures apparently see 'cunning' as an important 
leadership trait while others see it as a major problem for leaders; High power-distance societies are expected to foster authority-based leadership relationships more than others; Collectivist cultures are seen to value and foster inclusive leadership models more than individualistic cultures do. Studies also suggest different leadership models prevail in different organizational types with hierarchies characterized by authority-based leadership and flatter organizations espousing team-based leadership mechanisms.

Such studies commonly describe leadership structures in developing countries as patrimonial, ${ }^{\text {xli }}$ characterized by a directive leadership style that emphasizes status (authority) and social engagement. They ascribe this style to the (apparently) higher power distance tendencies in these societies, strong family bonds, a sense of fatalism, and the expectation that organizations like the government will take care of people. Surely people will identify leaders of change because of their position in such settings rather than their functional contribution? Surely people will look to individual leaders to make a difference instead of groups? We could raise similar questions about public bureaucracies, given theories that different leadership styles work differently (are contingent upon) different contexts. ${ }^{\text {xlii }}$ Weber developed an entire leadership profile to match bureaucratic structures and authors over the years have described 'leadership' in bureaucracies using terms like 'conservator'. ${ }^{\text {xliii }}$ Surely government bureaucracies are unlikely to exhibit leadership by non-authorized people in horizontal teams, involving acts of double-loop learning and deep organizational analysis? Surely change can be achieved in these settings through the strong leadership of an individual at the top of the organizational hierarchy, given the authority and influence he (probably) has?

We do not believe so, and suggest that models people commonly allude to as evidence of individual leader-led change in such settings miss out on the larger reality that changeinducing leadership is always group based, involving multiple parties (and functions) and successful because of the change space it creates. Presidents Park of Korea and Lee Kuan Yew of Singapore certainly opened opportunities for modernization in their countries, but the leadership that took these countries towards developed status involved many people, organizations and groups over many years and not just the top leaders. Nelson Mandela is the model of an individual transformational leader, but research suggests his influence was strongly augmented by the social structures in the African National Congress and beyond. ${ }^{\text {xliv }}$ Such observations are commonplace in the work of Adrian Leftwich's Leaders, Elites and Coalitions team, which argues that "Successful and sustained development depends crucially on whether, why and how various leaders and elites across the public and private domains are able to form sufficiently inclusive 'developmental coalitions' (or growth coalitions), formal or informal.”

Given this line of argument, we hold that leadership only enhances change space (hence facilitating change) when it is expressed through groups and where the members of these groups engage in coordinated, functionally appropriate ways (See Andrews 2008b). These group-based solutions will look different in different contexts—perhaps being more structured across bureaucracies than in flatter organizations for example-but they are vital to the idea of leadership-led change. We also believe leadership-led change experiences will be contextual-meaning there will be antecedent events that ready the context for such leadership and factors that shape it. These could include gradual developments along a steady path (like the promotion of a civil society that might create 
growing demand for leadership that allows open access) or it might involve conjunctive events that destabilize a path (a shock that brings key players together in coalitions of necessity, for example). Where the context is not ready for this kind of change-inducing leadership and societies are locked into models that do not accommodate such leadership, we believe change will be limited (either for all or to a small group, commonly elites) and development will be undermined. Limited change space in these contexts will have similar effects as low fitness does for biological organisms facing evolutionary adjustment: they stagnate and ultimately fall behind those who are fitter. This, we believe, is a large part of the story about development failure (suggested in Figure 2).

\section{Examining our propositions: A Method}

We do not intend to raise these propositions for theoretical exploration only. They emerge against the backdrop of real, practical engagements focused on stimulating development through leadership promotion. In 2007 a multi donor group called the Global Leadership Initiative (GLI) put out a call for examples of these kinds of interventions and received over 100 responses. 50 cases were written up, documenting different approaches to promote leadership-led change already being taken by developing country governments themselves, multi- and bi-laterals and non-profits and private organizations. These include rapid results interventions, visioning strategies, negotiations space initiatives, group-based planning exercises and many others.

In 2008 The GLI began asking questions about whether these interventions were fostering solutions to problems and how these solutions worked. The intention of these questions was not to conduct evaluations but rather to learn lessons and begin understanding how change really happens in the development process and what role leadership can play in such: And whether anything can be gained from interventions that mean to spark leadership-led change approaches. Our theoretical discussion frames propositions for researching these questions and the current section presents a research method behind just such an empirical study, results of which are presented later.

\section{Research approach and data sources}

Our research propositions attempted to shed light on how change works and how leadership can catalyze change. A common research strategy adopted for such work, employed in studies like Hennessey (1998) and Rimmer et al. (1996), involves identifying a set of organizations undergoing change and using qualitative data collection mechanisms and content analysis of this data to investigate how change occurs and how leadership manifests in the change process. Applying such approach, we identified 14 change engagements in 8 developing countries, listed in Table 1, interviewed people who had been involved in these processes, and analyzed the content of these interviews to see if our propositions had any empirical support. Our goal was not so much to prove our propositions correct, as if these propositions were the final stop on a theoretical journey. Rather, we intended to see whether there was evidence to suggest the propositions pointed towards valuable insights for theory and practice and to gain information on how the propositions might be more substantiated (or more tightly specified). 
Table 1. Cases selected for inclusion in the analysis

\begin{tabular}{|c|c|}
\hline Country/Intervention (period) & Source of fragility \\
\hline 1. Afghanistan Civil Service Leadership Program for Top Officials (06-08) & Post conflict, no capacity \\
\hline 2. Afghanistan: Towards a National Plan (2002) & Post conflict, no capacity \\
\hline 3. Burundi Governance, Leadership Capacity Development (07-09) & $\begin{array}{c}\text { Post conflict, no service } \\
\text { delivery }\end{array}$ \\
\hline 4. Central African Republic 2004 Leadership Seminar & Post conflict, state building \\
\hline 5. Central African Republic 2005 Leadership Workshop & Post conflict, state building \\
\hline 6. Kenya Results Based Management (04-09) & Service delivery failures \\
\hline 7. Kenya : Strengthening the Role of the National Assembly (00-09) & $\begin{array}{c}\text { Weakened executive, } \\
\text { growing democracy }\end{array}$ \\
\hline 8. Kosovo: Municipal Anti- Corruption Initiative (04-06) & Post conflict, state building \\
\hline 9. Rwanda: Rapid Results (07-09) & State building, Service failure \\
\hline 10. Rwanda Imihigo: Results-Based Services (07-09) & New local govts., Services \\
\hline 11. Sierra Leone: Club de Madrid African Women Leaders (2007) & Post conflict, women in govt. \\
\hline 12. Sierra Leone: Rapid Results (04-09) & Post conflict, new local govts. \\
\hline 13. Uganda: Leadership Preparation for a Government Transition (2006) & $\begin{array}{c}\text { Transition to multi-party } \\
\text { govt. }\end{array}$ \\
\hline 14. Uganda Leadership Forum for Ministers, Permanent Secretaries (2007) & $\begin{array}{c}\text { Transition to multi-party } \\
\text { govt. }\end{array}$ \\
\hline
\end{tabular}

We chose cases in countries that could be called fragile and where we knew a change intervention had occurred. These are extreme cases where development seems frustrated by constraints and leadership is often felt by its absence (Collier 2007). Given the high case variation (across countries and sources of fragility), we needed as robust a research protocol as possible - such that we captured information about similar things across the different contexts, to allow comparison. We developed a common questionnaire for this purpose, comprising a mixture of open and closed ended questions about the respondents, the problem being addressed in the intervention, contextual factors that contributed to the problem, the intervention, and results following the intervention. A set of questions interspersed throughout the instrument focused on leadership, specifically allowing us to talk to the propositions we raised about who and why, what and how leadership matters to change and development.

The instrument was pre-tested in telephone-based interviews and slightly adjusted as a result; all other interviews were conducted face-to-face in the countries themselves. Four primary interviewers were involved (one in Africa, one in Kosovo and two in Afghanistan) and interview data was captured in writing and through voice recording (in most cases). Written data was collected into a single spreadsheet and a selection of the data (about $30 \%)^{\mathrm{xlv}}$ was verified against the recordings. There was no evidence of consistent inaccuracy in the written collection process or of bias between the interviewees. ${ }^{\text {xlvi }}$ Table 2 shows that the number of interviews was not large, in any individual case. This may worry some readers, but similar studies typically use small samples from specific change entities or events and emphasize focusing less on ensuring a representative sample of interviewees and more on accessing quality data from a selected set. Data collected in each interview is extremely thick as a result, and takes multiple forms (closed numeric answers and narratives, for example) to help ensure we captured detailed and reliable perspectives in the interviews conducted. The aim is not to 
generalize to the population of potential interviewees and tell the full story of each case but to observe patterns across the cases that allow inference from the data to theory, which we believe the approach allows.

Table 2. Interviewee data and concerns about bias

\begin{tabular}{|c|c|c|c|}
\hline Country/Intervention & Interviewees & $\%$ Male & $\begin{array}{l}\% \text { in } \\
\text { govt. }\end{array}$ \\
\hline Overall & 148 & $77 \%$ & $74 \%$ \\
\hline 1. Afghanistan Civil Service Leadership (06-08) & 22 & $91 \%$ & $73 \%$ \\
\hline 2. Afghanistan: Towards a National Plan (2002) & 13 & $92 \%$ & $69 \%$ \\
\hline 3. Burundi (07-09) & NA & NA & NA \\
\hline 4. Central African Republic (04-05) & 7 & $86 \%$ & $72 \%$ \\
\hline 5. Kenya Results Based Management (04-09) & 17 & $65 \%$ & $94 \%$ \\
\hline 6. Kenya : National Assembly (00-09) & 7 & $43 \%$ & $0.00 \% *$ \\
\hline 7. Kosovo: Municipal Anti- Corruption (04-06) & 16 & $88 \%$ & $88 \%$ \\
\hline 8. Rwanda: Rapid Results (07-09) & 15 & $60 \%$ & $60 \% * *$ \\
\hline 9. Rwanda Imihigo(07-09) & 15 & $100 \%$ & $80 \%$ \\
\hline 10. Sierra Leone: Club de Madrid (2007) & 8 & $13 \%$ & $75 \%$ \\
\hline 11. Sierra Leone: Rapid Results (04-09) & 12 & $100 \%$ & $66 \%$ \\
\hline $\begin{array}{l}\text { 12. Uganda: Leadership Preparation for a Government } \\
\text { Transition (06-07) }\end{array}$ & 11 & $64 \%$ & $100 \%$ \\
\hline
\end{tabular}

* More than half interviewees were in the main contractor working with parliament.

** About a third comprised citizens participating directly in the initiative.

The number of interviews we managed to conduct varied across countries. This reflects our sampling approach, logistical problems in some contexts and the nature of the interventions themselves, and certainly requires some consideration in discussing results:

- We took a purposeful approach to sampling by asking GLI partners to identify potential interviewees in different categories-especially reflecting what the literature calls agents and targets of change. ${ }^{\text {xlvii }}$ We managed to access initial interviews from this list and then allowed snowballing to find unidentified interviewees. Both the selective identification and snowballing approaches have their weaknesses, but we believe they were appropriate for the study at this stage - especially given the novel nature of researching leadership-led change in fragile developing countries.

- We did run into logistical problems in accessing some of the selected interviewees in the limited periods of time interviewers were in countries (approximately 5 days for each intervention) which is one reason why numbers are lower in the Central African Republic, Kenyan Parliamentary, Sierra Leone Club de Madrid and Ugandan cases. It proved particularly difficult to access very high level officials in these contexts. We have no interviews from Burundi because of such problems, but we were able to conduct a participant observation study of an all-cabinet rapid results workshop. This formed the basis of our assessment here, which we present as different to the others. 
- It is also important to note that the smaller interviewee numbers in cited cases also reflected the narrower nature of these interventions and sometimes the lag between when the intervention occurred and the research. We found snowballing was especially limited in respect of these interventions, partly because we seemed to either have most people on our initial lists or because people had moved on since the interventions. In the case of the two Central African Republic (CAR) and two Ugandan interventions, we found the initial lists overlapped substantially and interviewees considered events as part of the same process. We present data together in both cases, therefore; the consolidation reduces our number of cases to 12 .

Table 2 shows obvious forms of bias in the interviewee sample. 77 percent of the interviews were conducted with male respondents and 74 percent of the interviewees worked in government in the country in question. We reflect on potential bias in the research findings discussed hereafter, but also note that the bias could have been expected given that we are focusing on formal development work in developing countries which is dominated by government entities and many suggest by men as well (especially in patriarchal countries, dominating our set of cases). There is also an implicit suggestion that the nature of GLI-identified interventions themselves may have promoted such biases. One should note that some interviewee groups do not exhibit these biases, partly because of the design and focus of the intervention: Females dominate interviewees in respect of the Club de Madrid work in Sierra Leone, for example and almost half of the Rwanda Rapid Results interviewee pool comprised women and non-government agents, with citizens actually making up a sizeable portion. This distribution certainly seems to reflect the fact that the Club de Madrid work had a focus on raising the role of women parliamentarians and the Rwanda Rapid Results work focused on local-level development.

\section{Ensuring the cases matched our expectations}

We thought it important to ensure that the cases chosen for analysis were indeed the extreme cases of leadership-led change we assumed in the selection process. The 2007 case descriptions (and other materials) developed by GLI suggested that the focal cases involved situations where, (i) countries were in tenuous positions facing major change demands, (ii) change was indeed evident in and hopefully through specific interventions, and (iii) the change had been catalyzed by basic approaches to promote leadership (all details shown in Table 3). We asked questions in regard to these three assumptions to act as controls—allowing us to verify that all cases were at least similar in the three noted respects.

The first control questions asked if the interviewees agreed with a statement we had prepared describing the tenuous position faced at the time of the intervention (similar to that presented in Table 3 and developed from wording in the GLI case descriptions). We intended to see whether interviewees did indeed see the situation as tenuous and fragile and whether they had common perspectives on what the fragility entailed. Overall, 80 percent of the interviewees agreed with our statement directly, or with some minor adjustment, clarification or addition. ${ }^{\text {xlviii }}$ While there were some interesting differences in 
perspective on the nature of the problem (which we discuss later), there was no case where a majority of interviewees disagreed that the initial context was fragile.

Table 3. Basic details about each case and intervention

\begin{tabular}{|c|c|c|c|}
\hline $\begin{array}{c}\text { Country/ } \\
\text { Intervention }\end{array}$ & Problem being addressed & $\begin{array}{c}\text { Basic approach in the } \\
\text { intervention }\end{array}$ & $\begin{array}{l}\text { Intended influence (change and } \\
\text { leadership) of the intervention }\end{array}$ \\
\hline $\begin{array}{l}\text { 1. Afghanistan } \\
\text { Civil Service } \\
\text { Leadership (06- } \\
08 \text { ) } \\
\end{array}$ & $\begin{array}{c}\text { The new government was being } \\
\text { built after } 30 \text { years of conflict } \\
\text { and lacked a top and middle } \\
\text { layer of civil servants }\end{array}$ & $\begin{array}{c}\text { Training in Germany } \\
\text { through discussion } \\
\text { groups on various } \\
\text { topics } \\
\end{array}$ & $\begin{array}{l}\text { Develop cadre of top and middle } \\
\text { level leaders/managers in the } \\
\text { Afghan govt. }\end{array}$ \\
\hline $\begin{array}{l}\text { 2. Afghanistan: } \\
\text { Towards a } \\
\text { National Plan } \\
\text { (2002) }\end{array}$ & $\begin{array}{l}\text { Afghan Govt. lacked any kind } \\
\text { of vision or focus, around } \\
\text { which to organize and structure }\end{array}$ & $\begin{array}{l}\text { National plan creation } \\
\text { process; Critical } \\
\text { Stakeholder Enquiry, } \\
\text { Visioning Process }\end{array}$ & $\begin{array}{l}\text { Establish a National Development } \\
\text { Framework to guide the Afghan } \\
\text { govt., and facilitate leadership } \\
\text { cohesion }\end{array}$ \\
\hline $\begin{array}{l}\text { 3. Burundi (07- } \\
\text { 09) }\end{array}$ & $\begin{array}{l}\text { Govt. emerging from peace } \\
\text { deal still lacked structure and } \\
\text { particularly struggled to } \\
\text { provide services }\end{array}$ & $\begin{array}{l}\text { Cabinet retreats, } \\
\text { Training of trainers, } 60 \\
\text { Rapid Results Pilots }\end{array}$ & $\begin{array}{l}\text { Improve service delivery and } \\
\text { confidence, accountability, and } \\
\text { effectiveness of leadership in } \\
\text { service delivery processes. }\end{array}$ \\
\hline $\begin{array}{l}\text { 4. Central African } \\
\text { Republic (04-05) }\end{array}$ & $\begin{array}{c}\text { Govt. had emerged from } \\
\text { conflict but there was limited } \\
\text { consensus about what it should } \\
\text { do and limited legitimacy }\end{array}$ & $\begin{array}{c}2 \times 2 \text { Day high level } \\
\text { consultations, Peer } \\
\text { Exchange, Rapid } \\
\text { Results Pilots } \\
\end{array}$ & $\begin{array}{l}\text { Build political consensus around } \\
\text { governing priorities especially } \\
\text { leading up to election; achieve } \\
\text { quick results to build legitimacy }\end{array}$ \\
\hline $\begin{array}{l}\text { 5. Kenya Results } \\
\text { Mgmt. (04-09) }\end{array}$ & $\begin{array}{c}\text { Adjustment at end of Moi } \\
\text { Administration led to increased } \\
\text { urgency in govt. and pressure } \\
\text { for service delivery }\end{array}$ & $\begin{array}{l}\text { Rapid Results Pilots in } \\
53 \text { ministries tied to } \\
\text { broader results based } \\
\text { management reforms }\end{array}$ & $\begin{array}{c}\text { Improve service delivery in key } \\
\text { areas, mainstream results-based } \\
\text { mgmt. in govt, develop required } \\
\text { leadership structures }\end{array}$ \\
\hline $\begin{array}{c}\text { 6. Kenya : } \\
\text { National } \\
\text { Assembly (00-09) }\end{array}$ & $\begin{array}{l}\text { Pressures for more accountable } \\
\text { administration were growing } \\
\text { and reflected in pressure to } \\
\text { strengthen Parliament }\end{array}$ & $\begin{array}{l}\text { Workshops, Study tours } \\
\text { and other interventions }\end{array}$ & $\begin{array}{l}\text { Strengthen leadership role of } \\
\text { Parliament and accountability of } \\
\text { govt. as a whole }\end{array}$ \\
\hline $\begin{array}{l}\text { 7. Kosovo: } \\
\text { Municipal Anti- } \\
\text { Corruption (04- } \\
\text { 06) }\end{array}$ & $\begin{array}{l}\text { New municipalities were } \\
\text { emerging in Kosovo but } \\
\text { concerns about corruption and } \\
\text { management control were high }\end{array}$ & $\begin{array}{l}\text { Participatory needs } \\
\text { assessment, Code of } \\
\text { Ethics, Consensus } \\
\text { building, Cooperative } \\
\text { planning, advocacy } \\
\end{array}$ & $\begin{array}{l}\text { Develop leadership structures in } \\
\text { municipal inspectorates to ensure } \\
\text { effective controls on corruption }\end{array}$ \\
\hline $\begin{array}{l}\text { 8. Rwanda: Rapid } \\
\text { Results (07-09) }\end{array}$ & $\begin{array}{l}\text { Govt. lacked mechanisms for } \\
\text { governing and delivering } \\
\text { services in new districts }\end{array}$ & Rapid Results pilots & $\begin{array}{l}\text { Implement integrated local } \\
\text { development program among hard } \\
\text { to reach groups by developing } \\
\text { localized leadership mechanisms }\end{array}$ \\
\hline $\begin{array}{l}\text { 10. Rwanda } \\
\text { Imihigo: (07-09) }\end{array}$ & $\begin{array}{c}\text { Govt. lacked mechanisms for } \\
\text { governing and delivering } \\
\text { services in new districts }\end{array}$ & $\begin{array}{l}\text { Performance contracts, } \\
\text { public meetings for } \\
\text { evaluation and others } \\
\end{array}$ & $\begin{array}{c}\text { Promote localized processes of } \\
\text { identifying and solving } \\
\text { development problems }\end{array}$ \\
\hline $\begin{array}{l}\text { 10. Sierra Leone: } \\
\text { Club de Madrid } \\
(2007)\end{array}$ & $\begin{array}{l}\text { Emerging from conflict, Sierra } \\
\text { Leone committed to increase } \\
\text { leadership role of women }\end{array}$ & $\begin{array}{l}\text { Peer engagement with } \\
\text { heads of state, advocacy } \\
\text { action, mentoring }\end{array}$ & $\begin{array}{l}\text { More women in Parliament and } \\
\text { govt. and better perceptions about } \\
\text { women political leaders. }\end{array}$ \\
\hline $\begin{array}{c}\text { 11. Sierra Leone: } \\
\text { Rapid Results } \\
(04-09) \\
\end{array}$ & $\begin{array}{l}\text { Govt. lacked mechanisms for } \\
\text { governing, delivering services } \\
\text { in new local government }\end{array}$ & Rapid Results pilots & $\begin{array}{c}\text { Build local capacity, foster service } \\
\text { delivery and structures for } \\
\text { delivering services }\end{array}$ \\
\hline $\begin{array}{l}\text { 12. Uganda: } \\
\text { Leadership } \\
\text { Preparation for a } \\
\text { Government } \\
\text { Transition (06-07) }\end{array}$ & $\begin{array}{l}\text { Uganda would have a multi- } \\
\text { party democracy for first time, } \\
\text { and govt. structures and } \\
\text { processes needed to change to } \\
\text { accommodate this transition }\end{array}$ & $\begin{array}{c}4 \text { day workshop, } \\
\text { knowledge exchange, } \\
\text { plan for incoming } \\
\text { government; Twinning, } \\
\text { Training, Job } \\
\text { shadowing; Mentoring }\end{array}$ & $\begin{array}{l}\text { Develop a plan reflecting multi- } \\
\text { party policies, as well as processes } \\
\text { for policy decision-making, } \\
\text { communication, implementation } \\
\text { etc. in new govt. structures; and } \\
\text { assist govt. leadership to make the } \\
\text { transition to non-partisan work }\end{array}$ \\
\hline
\end{tabular}


Later control questions asked if the problem had been better addressed since the intervention (with intended impacts described briefly in the final column of Table 3), whether the intervention contributed to this, and whether leadership had improved since the intervention. Again, we were satisfied that results (shown in Table 4) suggested evidence of leadership-led adjustment in each case.

Table 4. Evidence of change and leadership 'impacts' in these extreme cases

\begin{tabular}{|c|c|c|c|}
\hline Country/Intervention & $\begin{array}{c}\text { The problem has } \\
\text { been better } \\
\text { addressed }\end{array}$ & $\begin{array}{c}\text { The } \\
\text { intervention } \\
\text { contributed }\end{array}$ & $\begin{array}{c}\text { Leadership } \\
\text { has } \\
\text { improved }\end{array}$ \\
\hline Overall & $89 \%$ & $90 \%$ & $77 \%$ \\
\hline 1. Afghanistan Civil Service Leadership (06-08) & $73 \%$ & $73 \%$ & $59 \%$ \\
\hline 2. Afghanistan: Towards a National Plan (2002) & $69 \%$ & $65 \%$ & $54 \%$ \\
\hline 3. Burundi (07-09) & NA & NA & NA \\
\hline 4. Central African Republic (04-05) & $86 \%$ & $86 \%$ & $57 \%$ \\
\hline 5. Kenya Results Based Management (04-09) & $100 \%$ & $100 \%$ & $94 \%$ \\
\hline 6. Kenya : National Assembly (00-09) & $100 \%$ & $100 \%$ & $75 \%$ \\
\hline 7. Kosovo: Municipal Anti- Corruption (04-06) & $100 \%$ & $100 \%$ & $71 \%$ \\
\hline 8. Rwanda: Rapid Results (07-09) & $87 \%$ & $87 \%$ & $93 \%$ \\
\hline 9. Rwanda Imihigo(07-09) & $100 \%$ & $100 \%$ & $100 \%$ \\
\hline 10. Sierra Leone: Club de Madrid (2007) & $88 \%$ & $88 \%$ & $88 \%$ \\
\hline 11. Sierra Leone: Rapid Results (04-09) & $92 \%$ & $92 \%$ & $83 \%$ \\
\hline 12. Uganda: Leadership Preparation for a & $100 \%$ & $91 \%$ & $64 \%$ \\
\hline Government Transition (06-07) & & &
\end{tabular}

There is variation in Table 4 data, however. While about 90 percent of interviewees overall identified an improved situation to which the intervention contributed, the statistics from both Afghan cases in particular suggest lower levels of enthusiasm. Interviewees in Afghanistan seemed more reluctant to say that the problem had been better addressed and the interventions had contributed to improvements. More than a quarter of interviewees in these groups resisted answering "yes” to these questions, suggesting that change may have been (subjectively) less forthcoming than in other cases.

We asked interviewees to describe their binary yes or no answers in more detail, so as to strengthen reliability of the data and allow us to better understand answers. Negative respondents in the Afghan cases noted (amongst other comments): "I don't see improvement"; "These [capacity constraints] are not priorities"; "Were we better able to do our jobs? I could not see”. These were countered by more positive statements by a larger portion of the interviewees, in comments like: "We had deputy ministers who were not helping each other although their work required cooperation between the ministries. Now they pick up a phone and call each other and things get done very quickly"; "After the deputy minister came back... he started making a daily list, every day he makes sure the list gets done. He follows up and makes sure that the tasks are completed. He has more contact with his staff as well"; "Yes, the staff is now using computers and new technology. Also, before, the staff was not able to speak and write English and use the internet, but now they can." 
Table 5 shows abbreviated versions of the positive and less enthusiastic comments emerging from interviews in the Afghan Civil Service case. The positive comments outweigh the less enthusiastic comments even in this case. There were more of the latter less enthusiastic comments in this than any other case.

\section{Table 5. Descriptions of change 'impact' in the Afghan Civil Service case}

\section{Comments interviewees offered when asked, "Has the problem been better addressed?"}

\section{Positive comments}

- Those who were trained, they have been better in their performance in several areas.

- We had deputy ministers completely opposed to reform, the idea of reform. After they attended the program, they became very strong supporters of reform.

- In some institutions decision making, delegation, communication and supervision have improved...the implementation of public administrative reform had been in a better shape [in these] than in other institutions and other ministries.

- You can see a lot of changes in terms of better understanding strategic planning, planning day-to-day work, how to manage work, merit-based recruitment...Most ministries [now] have the reform program of the Civil Service Commission.

- Through all these initiatives and programs, you can see a new generation of leaders in some of the ministries. They learned by doing, participating in the exposures.

- After the deputy minister came back... he started making a daily list, every day he makes sure the list gets done. He follows up, makes sure tasks are completed. He has more contact with his staff as well.

- Yes, the staff is now using computers and new technology. Also, before, the staff was not able to speak and write English and use the internet, but now they can.

- Participants made the best use of that training. They are proving it. I see them, I look at them. I see changes here happening.

- When the deputy minister came back the performance of the Ministry improved.

- Improvements have happened, and we are seeing it.

- We achieved a great deal, removed most major obstacles from earlier.

- Before I went to the training, I could not explain 'leader,' or what is my responsibility here. I learned about this, and now I'm good.

Less enthusiastic comments

- No. There's not much focus on this now.

- The training is still needed in all the ministries.

- It was too little. It's a small group of people who have done it.

- A lot of the deputy ministers said they needed follow-up training.

- Of course we had a few that at the end of the program; we thought it was a waste of money.

- Still, the major issue remains: instability and insecurity. As long as we have instability in the country, the process of reform will face some bumps on the road.

- Were they better able to do their jobs? I could not see. I don't see improvement.

- No. The patient was misdiagnosed. They thought, you know, you send them to a conference in Germany, that Max Planck came, or some institute came, the British Council came and somebody else came, and conferences. That's not going to fix this. Because the real deliverables of the Afghan government were never defined. If you don't know where you're going, you will never get there.

Narrative data like that in Table 5 lends support to the binary answers captured in Table 4. When considered together for each case, we found that the data suggested that there was positive change in even the most disputed cases (the Afghan civil service intervention, as shown in Table 5). The variation in the amount of change is interesting to note, however, and allows some thinking on how far change may have progressed in different cases and whether different interventions may have occurred at different stages in the change process and fostered different types of progress (see Figure 3 and Annex 1): 
- Comments about Afghanistan's Civil Service Leadership Program, for example, reflect that early diagnosis of the problem was not complete and the initiation of the Program may in fact have shown this to be the case. One commentator suggested, "You know, if as a doctor, you misdiagnose, and prescribe the wrong treatment, your patient isn't going to survive, isn't going to get better. That is the case of the Afghan civil service. The patient was misdiagnosed.” Perhaps the change process in Afghanistan should double back from initiation to pre-conceptualization to ensure lessons from the intervention are captured and translated into better diagnoses?

- In the participant observation of Burundi's rapid results initiative we saw an intervention in the initiation stages, where government has pursued pilots to investigate whether the rapid results method is appropriate for broader implementation. The workshop we attended gave Cabinet an opportunity to vet the pilots and determine whether they would expand the intervention and move towards a more permanent next step: Perhaps transition towards fuller adoption or backwards to a fuller conceptualization of problems better observed in the pilots?

- In Uganda we felt that the intervention supported a change process that was already happening (given that elections had already introduced a multiparty system). The intervention seems to have facilitated transition where many pre-existing leadership structures were slightly improved but not totally re-structured. Interviewees identified a variety of initiatives emerging after the intervention to institutionalize changes from the intervention. Statements included: "An annual policy retreat is [now] held"; "Cabinet forums on policy communication have been developed"; "There is now an on-going dialogue around vision, time management, decision-making — and the discussions are leading to creating a committee system in cabinet.”

We did not structure the questionnaire to identify where the intervention occurred in the change process or how far change processes have developed in each case, but we do believe there is variation. The variation does not, however, undermine evidence of change and leadership improvement in all cases within the context of Pettigrew's "untidy cocktail” of the change process.

\section{Examining leadership-led change propositions: Results and discussion}

Given that we found evidence of some change and leadership improvement in all cases, we turn to presenting and discussing results pertinent to our research propositions on leadership-led change. We organize this to reflect our focal questions: Who is the change leader? Why? What does the leader do? How? How does context influence leadership?

\section{Leadership's 'who' and 'why'}

We raised two research propositions about who seems to provide leadership in change contexts and why they are identified as doing so. The first proposition suggested that leadership is more about groups than individuals, and we would thus expect that multiple parties exercise leadership in any successful change event. The second proposition held that 'leaders' are likely to be identified more because of their functional contribution to change than their personal traits or authority; we believed further that the 'connecting' function would stand out in situations of change (where someone connects the multiple parties involved). Table 6 summarizes evidence related to the first of these propositions. 
Table 6. Was there a leader? How many were identified?

\begin{tabular}{|c|c|c|c|}
\hline Country/Intervention & $\begin{array}{c}\text { \% Agreeing } \\
\text { "There was } \\
\text { a leader" }\end{array}$ & $\begin{array}{c}\text { Number of } \\
\text { leaders identified } \\
\text { (preceding } \\
\text { intervention) }\end{array}$ & $\begin{array}{c}\text { Number of } \\
\text { leaders identified } \\
\text { (following } \\
\text { intervention) }\end{array}$ \\
\hline Overall & $87 \%$ & 103 & 146 \\
\hline 1. Afghanistan Civil Service Leadership (06-08) & $86 \%$ & 7 & 20 \\
\hline 2. Afghanistan: Towards a National Plan (2002) & $100 \%$ & 17 & 12 \\
\hline 3. Burundi (07-09) & NA & NA & NA \\
\hline 4. Central African Republic (04-05) & $86 \%$ & 5 & 5 \\
\hline 5. Kenya Results Based Management (04-09) & $76 \%$ & 22 & 10 \\
\hline 6. Kenya : National Assembly (00-09) & $71 \%$ & 11 & 10 \\
\hline 7. Kosovo: Municipal Anti- Corruption (04-06) & $100 \%$ & 2 & 18 \\
\hline 8. Rwanda: Rapid Results (07-09) & $80 \%$ & 11 & 6 \\
\hline 9. Rwanda Imihigo(07-09) & $80 \%$ & 10 & 17 \\
\hline 10. Sierra Leone: Club de Madrid (2007) & $88 \%$ & 5 & 13 \\
\hline 11. Sierra Leone: Rapid Results (04-09) & $100 \%$ & 7 & 14 \\
\hline 12. Uganda: Leadership Preparation for a & $82 \%$ & 6 & \\
\hline Government Transition (06-07) & & & \\
\hline
\end{tabular}

\section{The multiplicity of leadership}

Table 6 first shows that, when interviewees were asked if there was a leader involved in the period preceding the intervention, 87 percent said yes. This suggested to us that there was indeed a clear identification with the idea of leadership in all contexts. We asked interviewees to identify who the leader was in this period, and heard 103 answers (from under 150 interviewees). There were at least two answers in each case, and more than ten in five of twelve cases. We asked the same question later in the interview (about who was leading now, since the problems were better addressed) and were told of 146 different parties - with more than ten 'leaders' identified in nine of the twelve cases.

Annex 2 provides the full listing of 'leaders' in these cases and also shows that one or two names were identified with more regularity than others in most cases. However, we did not come away with the identification of dominant players in any case but one (in Kosovo prior to the intervention, where the Director of Inspectors and the leadership promotion entity Partners for Democratic Change were identified). While we expected leadership multiplicity the large number of 'leaders' identified in the limited set of interviews was interesting and somewhat surprising; especially given we were interviewing people in apparently patrimonial cultures and (often) hierarchical organizations - where one might have expected some bias towards common interviewee identification of one or two ceremonial leaders or authority figures. The bias in our sample (towards men in government organizations) should have underscored such expectation. But, we did not find a majority of male Afghan respondents working in government identifying President Karzai as the 'leader' (even though the interventions we looked at were at the highest level of government) or many interviewees in Rwanda pointing to President Kagame as the 'leader' (as some suggested would be the case). 
Figure 8 maps the 'leaders' identified in Afghanistan's Civil Service Program, Kenya's Parliamentary intervention. Rwanda's Rapid Results Initiative (in the village of Gashaki only) and Uganda's leadership transition intervention in a network form-following Pemberton's (2000) policy networks approach used earlier to present the case of CINDE in Costa Rica (Figure 4 and Himelein and Andrews forthcoming). Each node in the network diagrams represents an identified 'leader' preceding the intervention (at left) and following the intervention (to the right) as organized into the four groupings Pemberton argues comprise a policy field; politics and government, private sector, international and issue actors. Bigger nodes show those leaders who had been identified more often than others. We do not show connections between nodes but simply how many 'leader' nodes there are, their relative prominence given our interviewee responses, and their groupings.

\section{Figure 8. 'Who' the leaders were in various cases, preceding and following interventions}

Fig. 8.a. Afghanistan's Civil Service Leadership Program
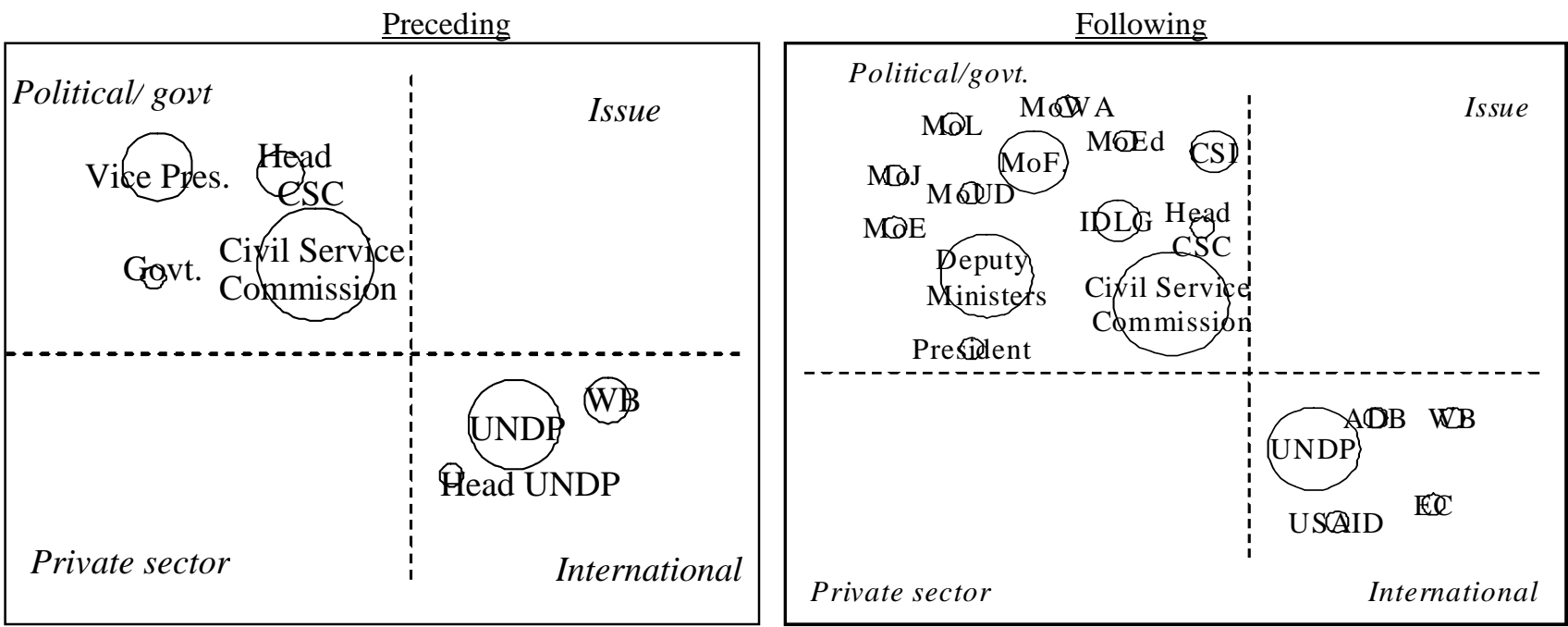

Fig. 8. b. Kenya's National Assembly Strengthening process

Preceding

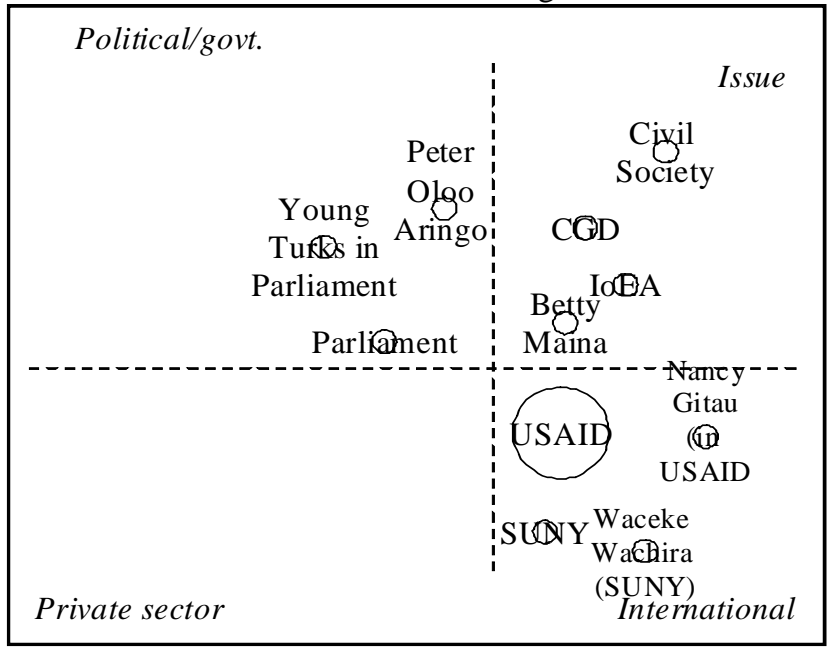

Following

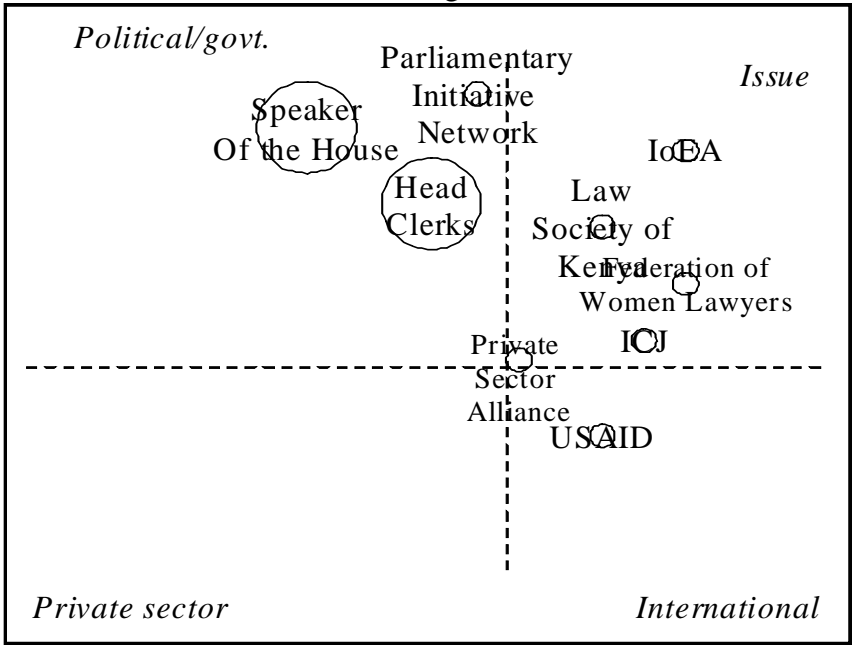


Fig. 8. c. Rwanda's Rapid Results (in the Gashaki community)

Preceding

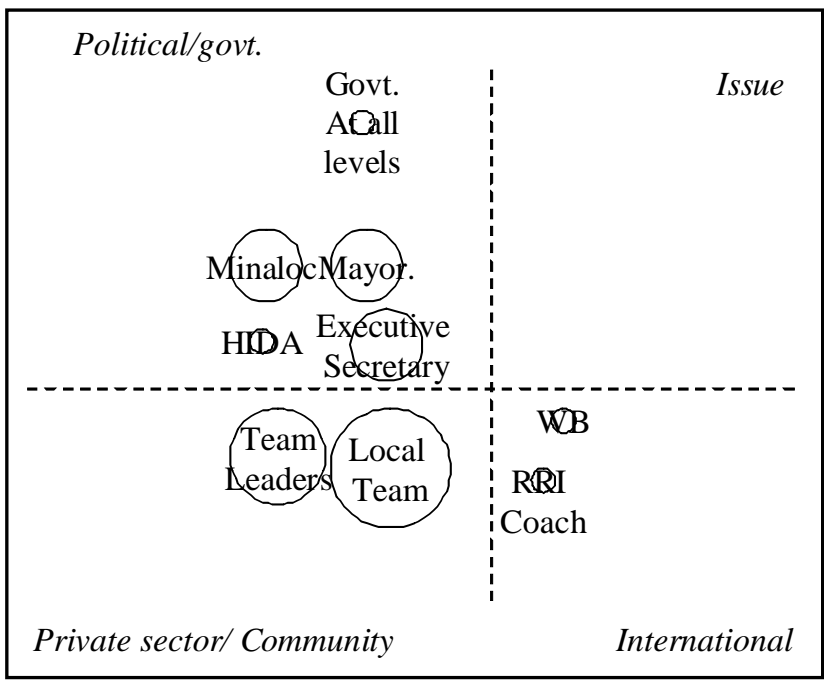

Fig. 8. d. Uganda's leadership promotion in transition Preceding

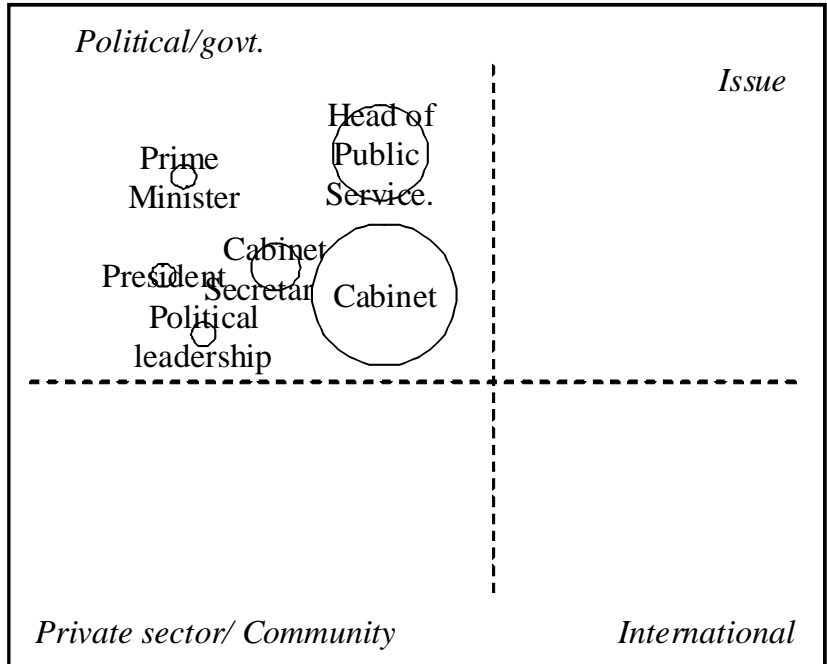

Following

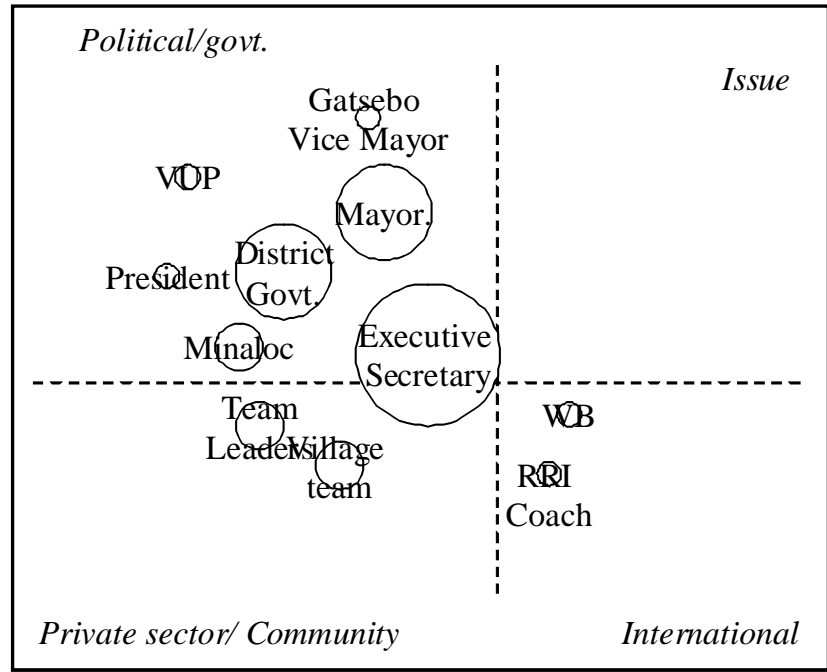

Following

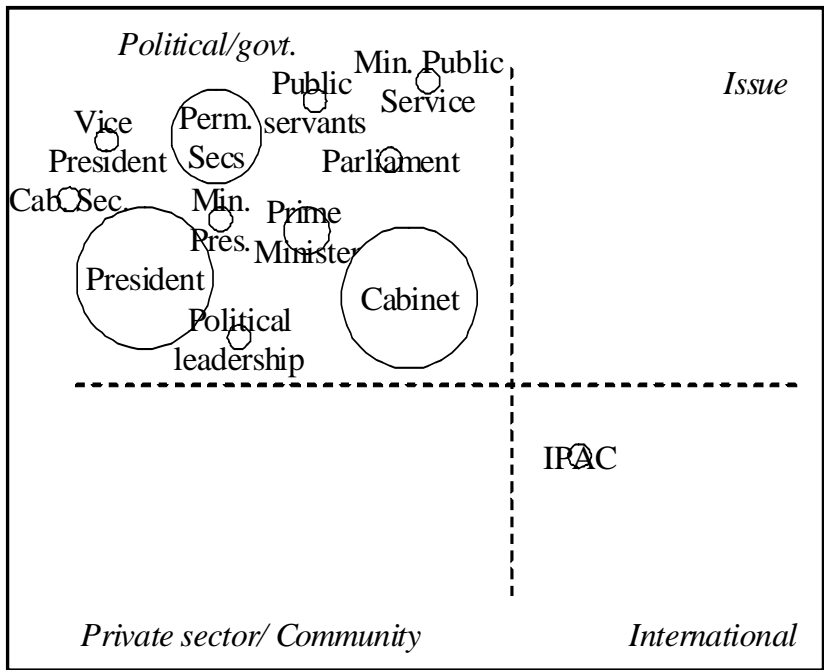

When considering the data in Table 6, Annex 2 and Figure 8 (a to d) we make the following basic observations, related to our first proposition:

- Interviewees in every case do identify multiple 'leaders'.

- Interviewees in most cases identify more leaders following the intervention — when change was more apparent-than preceding the intervention.

These observations suggest support for our leading proposition that there are always multiple leaders in any context and perhaps suggest we should speak of leaderships instead of leadership. We draw attention to other interesting observations as well. First, leaders are identified in different 'groupings' in different cases. 'Leaders' in the Afghan and Ugandan cases were predominantly identified in the political/government quadrant (with some in the international quadrant). This contrasts with the Kenyan and Rwandan examples where leaders were also in the Issue and Private Sector/Community quadrants. The variation implies a need to embrace differences in who leaders will be in different 
contexts, something we address later on. We also observe that there is variation in the type of entities called 'leaders' in every case. There are individuals (the Head of the Civil Service Commission in Afghanistan, Betty Maina in Kenya, and President Musuveni in Uganda, for example), organizations (the Civil Service Commission itself in Afghanistan, Law Society of Kenya and Cabinet in Uganda) and what we term social groups (like Civil Society in Kenya). Table 7 summarizes how many 'leaders' were identified with each group, preceding (in shaded columns) and following the interventions, in each case.

\section{Table 7. 'Leaders' as Individuals, Organizations and Social Groups}

\begin{tabular}{|c|c|c|c|c|c|c|}
\hline \multirow{2}{*}{$\begin{array}{c}\text { Country/ } \\
\text { Intervention }\end{array}$} & \multicolumn{2}{|c|}{$\begin{array}{c}\text { No. of individuals } \\
\text { identified }\end{array}$} & \multicolumn{2}{c|}{$\begin{array}{c}\text { No. of organizations } \\
\text { identified }\end{array}$} & \multicolumn{2}{c|}{$\begin{array}{c}\text { No. of social groups } \\
\text { identified }\end{array}$} \\
\cline { 2 - 7 } & $\begin{array}{c}\text { Preceding } \\
\text { intervention }\end{array}$ & $\begin{array}{c}\text { Following } \\
\text { intervention }\end{array}$ & $\begin{array}{c}\text { Preceding } \\
\text { intervention }\end{array}$ & $\begin{array}{c}\text { Following } \\
\text { intervention }\end{array}$ & $\begin{array}{c}\text { Preceding } \\
\text { intervention }\end{array}$ & $\begin{array}{c}\text { Following } \\
\text { intervention }\end{array}$ \\
\hline Overall & 35 & 55 & 58 & 85 & 10 & 16 \\
\hline $\begin{array}{c}\text { 1.Afghanistan } \\
\text { Civil Service } \\
\text { Leadership }\end{array}$ & 3 & 3 & 4 & 17 & 0 & 0 \\
\hline $\begin{array}{c}\text { 2.Afghanistan: } \\
\text { National Plan }\end{array}$ & 8 & 0 & 9 & 12 & 0 & 0 \\
\hline $\begin{array}{c}\text { 3. Burundi } \\
\text { 4.Cen. African } \\
\text { Republic }\end{array}$ & NA & NA & NA & NA & NA & NA \\
\hline $\begin{array}{c}\text { 5.Kenya } \\
\text { Results Mgmt. }\end{array}$ & 1 & 5 & 16 & 9 & 0 & 1 \\
\hline $\begin{array}{c}\text { 6. Kenya: } \\
\text { Nat. Ass. }\end{array}$ & 5 & 2 & 5 & 8 & 1 & 7 \\
\hline $\begin{array}{c}\text { 7. Kosovo: } \\
\text { Municipal }\end{array}$ & 1 & 5 & 1 & 5 & 0 & 0 \\
\hline $\begin{array}{c}\text { 8. Rwanda: } \\
\text { Rapid Results }\end{array}$ & 5 & 9 & 5 & 9 & 1 & 0 \\
\hline $\begin{array}{c}\text { 9. Rwanda } \\
\text { Imihigo }\end{array}$ & 3 & 5 & 6 & 6 & 1 & 3 \\
\hline $\begin{array}{c}\text { 10. Sierra } \\
\text { Leone: Club } \\
\text { de Madrid }\end{array}$ & 1 & 1 & 4 & 3 & 0 & 2 \\
\hline $\begin{array}{c}\text { 11. Sierra } \\
\text { Leone: R. Res }\end{array}$ & 1 & 6 & 5 & 9 & 1 & 2 \\
\hline 12. Uganda & 3 & 7 & 2 & 5 & 1 & 1 \\
\hline
\end{tabular}

The surprising finding is that interviewees identified organizations as leaders more often than individuals, overall and in the majority of cases. Some readers may feel that we should have pressed respondents to clarify whether they were talking about individuals, organizations or social entities, especially when we had some identifying an organization as the leader and others the head of that organization (as in the Civil Service Commission and its Head in Afghanistan). We did not press for clarification but in all cases asked interviewees to explain why they answered as they did. Such answers allowed us to check that the interviewee did mean what he/she said and we found no problems with answers (no examples where an organization was named but an individual described, for instance). Interviewees really did identify more organizations as 'leaders' than individuals, for the periods preceding and following interventions.

We suggested this as an interesting issue in the earlier theoretical section, building on prior research in which organizations like political parties and unions have been seen to play leadership roles in change processes. Some might interpret this as a form of quasi- 
patrimonial dependence people in developing countries have on formal organizations (which might have some validity given many interviewees did work for large organizations and some identified organizations to which they had allegiance as 'leaders'). In this case we could expect 'leader' organizations identified primarily because of the authorizing positions they occupy. Others might argue that organizations and institutions play real, functional roles in societies that extend beyond the individuals that temporarily inhabit them: A Parliament 'leads' in making law and setting the tone of legislation more than individual legislators do, perhaps. In such cases, 'leader' organizations would be identified because of their functional contributions.

\section{The functionality of leadership}

To clarify perspectives, we asked interviewees why they identified particular individuals, organizations or social groups as 'leaders'. Table 8 presents answers, organized into three broad categories alluded to in the earlier theory section: "Because they showed leadership traits", "Because of their position of authority" and "Because of the function they fulfilled.” A “trait” selection rationale was noted whenever interviewees explicitly referenced an attribute of the leader or related to key characteristics in comments like "he was the driver" or "he was well trusted" or "she was credible". An "authority" rationale was recorded where interviewees related comments like "it was their mandate", "he had the responsibility" or "it was in charge." A "functional” motivation was listed where interviewees commented on substantive contributions the 'leader' made to change, procedural contributions that aided groups to address change and maintenance contributions (facilitating relationships in the process).

Table 8. "Why" the leaders were identified

\begin{tabular}{|c|c|c|c|c|c|c|}
\hline \multirow{2}{*}{$\begin{array}{c}\text { Country/ } \\
\text { Intervention }\end{array}$} & \multicolumn{2}{|c|}{$\begin{array}{c}\text { Because they showed } \\
\text { leadership traits }\end{array}$} & \multicolumn{2}{c|}{$\begin{array}{c}\text { Because of their position } \\
\text { of authority }\end{array}$} & \multicolumn{2}{c|}{$\begin{array}{c}\text { Because of the function } \\
\text { they fulfilled }\end{array}$} \\
\cline { 2 - 7 } & $\begin{array}{c}\text { Preceding } \\
\text { intervention }\end{array}$ & $\begin{array}{c}\text { Following } \\
\text { intervention }\end{array}$ & $\begin{array}{c}\text { Preceding } \\
\text { intervention }\end{array}$ & $\begin{array}{c}\text { Following } \\
\text { intervention }\end{array}$ & $\begin{array}{c}\text { Preceding } \\
\text { intervention }\end{array}$ & $\begin{array}{c}\text { Following } \\
\text { intervention }\end{array}$ \\
\hline Overall & 14 & 13 & 50 & 49 & 91 & 87 \\
\hline $\begin{array}{c}\text { 1.Afghanistan } \\
\text { Civil Service }\end{array}$ & 3 & 0 & 13 & 11 & 16 & 12 \\
\hline $\begin{array}{c}\text { 2.Afghanistan: } \\
\text { National Plan }\end{array}$ & 2 & 0 & 4 & 5 & 2 & 4 \\
\hline 3. Burundi & NA & NA & NA & NA & NA & NA \\
\hline $\begin{array}{c}\text { 4.Cen. African } \\
\text { Republic }\end{array}$ & 3 & 1 & 2 & 2 & 5 & 2 \\
\hline $\begin{array}{c}\text { 5.Kenya } \\
\text { Results Mgmt. }\end{array}$ & 0 & 2 & 3 & 5 & 10 & 10 \\
\hline $\begin{array}{c}\text { 6. Kenya: } \\
\text { Nat. Ass. }\end{array}$ & 1 & 2 & 1 & 1 & 5 & 5 \\
\hline $\begin{array}{c}\text { 7. Kosovo: } \\
\text { Municipal }\end{array}$ & 1 & 2 & 7 & 5 & 7 & 9 \\
\hline $\begin{array}{c}\text { 8. Rwanda: } \\
\text { Rapid Results }\end{array}$ & 1 & 3 & 5 & 3 & 13 & 13 \\
\hline $\begin{array}{c}\text { 9. Rwanda } \\
\text { Imihigo }\end{array}$ & 1 & 2 & 5 & 6 & 9 & 11 \\
\hline $\begin{array}{c}\text { 10. Sierra } \\
\text { Leone: CdM }\end{array}$ & 2 & 1 & 0 & 1 & 5 & 6 \\
\hline $\begin{array}{c}\text { 11. Sierra } \\
\text { Leone: R. Res }\end{array}$ & 1 & 0 & 8 & 4 & 10 & 9 \\
\hline 12. Uganda & 0 & 0 & 2 & 6 & 9 & 6 \\
\hline
\end{tabular}


We found that interviewees often gave more than one reason for identifying their 'leader' and that a number linked two rationales together. In some cases the leader was seen as having a mandate (authority) and using the mandate to actually contribute (playing a functional role). In some instances an authorized leader also had important traits (could convince people, for example) and played a vital functional role (like building teams). Overall, as shown in Table 8 and Figure 9 (below), more interviewees noted the functional contribution of the 'leader' as a reason for identification in both the period preceding the intervention and following it than traits or authority.

Figure 9. 'Why' interviewees identified their leaders

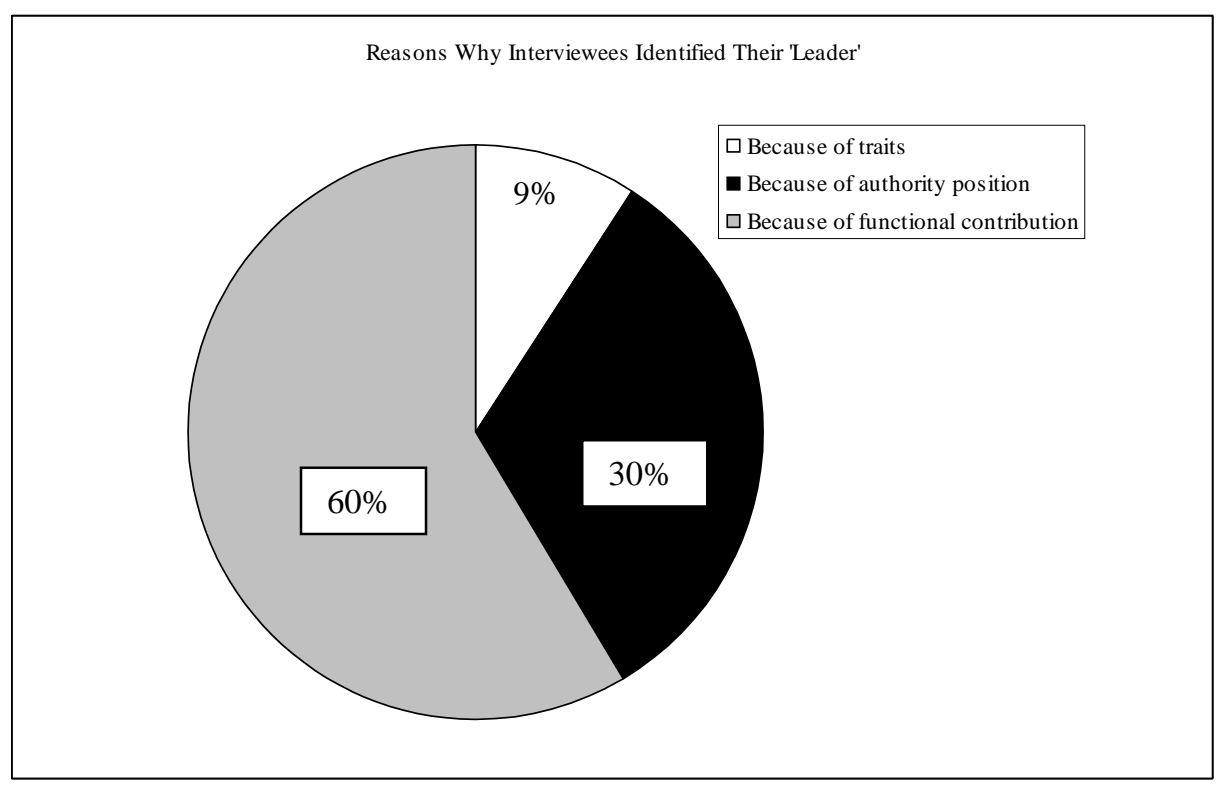

The data shows that traits and authority positions are still important identifiers of leaders, but not as important as function. This confirms our proposition that 'leaders' would be identified more because of their functional contribution to change than their personal traits or authority. This was the case for both individuals and organizations where the 'leader' organizations were often seen as the basis of funds, political support, and ideas (especially through international organizations). Even though we expected it, however, we are again interested in just how significant the result appears, especially given the context of the study and bias in the interview sample. Many would have argued that men in mostly hierarchical government organizations in patrimonial developing countries would identify with leaders primarily because of their traits and authority positions. But in change processes, it appears, leadership function is more important than form.

\section{Centrality of the 'connecting function'}

We expected to see that a 'connecting function' would stand out in all the cases, given the need to coordinate multiple leaders. This was certainly evident, with at least two interviewees in all cases alluding to such role and 44 references overall citing it as a reason for calling someone a leader (over 25 percent of the references). Interviewees used different language to describe the role (examples shown in Table 9) and mentioned different specific 'connector' activities like "inviting” people, "reaching out", "facilitating” engagement, "Bringing people together”, and "coordinating.” References 
also noted characteristics of 'leaders' fulfilling this function including "knew all parties", "was trusted"; "collaborated well with internal and external partners" and "connected well with all parties". These commentators echo our past descriptions of such role (Andrews 2008b) as involving parties who are

"Well known, liked, and trusted, and enjoy[ing] high levels of social capital...[can interact] well with people...[are] easily found...[can] engage well with people of all types, spanning boundaries ... open to questions about the status quo...attract people with problems and needs ... involved in multiple conversations... ha[s] a close group of contacts who in turn ha[ve] access to broad networks...bridge[s] boundaries groups set up between themselves... Resolutions emerge through the connections [the connector] enables."

One interviewee suggested the leader playing this role generally "took [a] back seat" and another mentioned that the connections empowered others to make decisions [rather than empowering the connector itself]. This also resonates with our prior observations (Andrews 2008b), "That the connector is often not the "formal face of the reform" and may not even be a primary beneficiary. This person may not even be the one who identified the reform need, conceptualized the idea, or provided the resources-but is the one who brings all those people together. "

\section{Table 9. Interviewees in all cases referred to a 'connector function' as vital}

\begin{tabular}{|c|c|}
\hline $\begin{array}{c}\text { Country/ } \\
\text { Intervention }\end{array}$ & Comments about a 'leader' fulfilling the 'connector' function \\
\hline $\begin{array}{l}\text { 1. Afghanistan Civil } \\
\text { Service Leadership (06-08) }\end{array}$ & $\begin{array}{c}\text { "Knew all parties and was talking with other parties"; "Got everyone } \\
\text { together"; "Invited people, shared it”; "Reached out to the most important } \\
\text { stakeholders who reached out to others" }\end{array}$ \\
\hline $\begin{array}{l}\text { 2. Afghanistan: Towards a } \\
\text { National Plan (2002) }\end{array}$ & "Facilitated discussion”; "Bought people together" \\
\hline 3. Burundi (07-09) & NA \\
\hline $\begin{array}{l}\text { 4. Central African Republic } \\
\text { (04-05) }\end{array}$ & $\begin{array}{l}\text { "Was crucial in securing consensus amongst all involved (he was neutral and } \\
\text { trusted and everyone came because he was there)"; "Connected all funders } \\
\text { like no one else could"; "Engaged with the external funders and the internal } \\
\text { delegations"; "Collaborated well with inside and outside partners" }\end{array}$ \\
\hline $\begin{array}{l}\text { 5. Kenya Results Based } \\
\text { Management (04-09) }\end{array}$ & $\begin{array}{l}\text { "Identified other partners and brings them all in"; "Plays coordinating role"; } \\
\text { "Introduced team members to each other so they could solve problems" }\end{array}$ \\
\hline $\begin{array}{l}\text { 6. Kenya : National } \\
\text { Assembly (00-09) }\end{array}$ & $\begin{array}{l}\text { "Knew a lot of people, engaged with parties then took back seat”; "Led } \\
\text { constructive engagement between stakeholders"; "Constantly engaging” }\end{array}$ \\
\hline $\begin{array}{l}\text { 7. Kosovo: Municipal Anti- } \\
\text { Corruption (04-06) }\end{array}$ & $\begin{array}{c}\text { "The team built around him because everyone trusted him"; "Collaborated } \\
\text { well” }\end{array}$ \\
\hline $\begin{array}{l}\text { 8. Rwanda: Rapid Results } \\
\text { (07-09) }\end{array}$ & $\begin{array}{l}\text { "Ensured the rest of government was on board"; "Convener that brings } \\
\text { players together" ; "Bought people together”; "Connected people together”; } \\
\text { "Coordinates well nationally”; "Coordinates well between people” }\end{array}$ \\
\hline 9. Rwanda Imihigo(07-09) & $\begin{array}{l}\text { "Bought the partners together"; "Can bring many partners in"; "Brings } \\
\text { people into the work"; "They get everyone involved” }\end{array}$ \\
\hline $\begin{array}{l}\text { 10. Sierra Leone: Club de } \\
\text { Madrid (2007) }\end{array}$ & $\begin{array}{c}\text { "They got everyone to come"; "Is very consultative"; "Engages well with all } \\
\text { the stakeholders" }\end{array}$ \\
\hline $\begin{array}{l}\text { 11. Sierra Leone: Rapid } \\
\text { Results (04-09) }\end{array}$ & $\begin{array}{l}\text { "Could pull in stakeholders"; "Facilitated discussions between key players"; } \\
\text { "They coordinate who is involved and which projects go through” }\end{array}$ \\
\hline $\begin{array}{l}\text { 12. Uganda: Leadership } \\
\text { Preparation (06-07) }\end{array}$ & $\begin{array}{l}\text { "Convinced the president and other parties to be engaged"; "Coordinator"; } \\
\text { "Communicated with the rest of the public service" }\end{array}$ \\
\hline
\end{tabular}




\section{Leadership's 'what' and 'how'}

We introduced a research proposition about what leaders do in change, and how, in which we emphasized the idea that leadership contributes to change when it builds change space. This, we proposed, involved leadership actions that foster acceptance for change, grant authority to change (with accountability), and introduce or free the abilities necessary to achieve change. We proposed that change space is especially enhanced where leadership facilitates open access societies and learning organizations in which members are empowered - in groups - to pursue change through problem solving.

There are obviously multiple parts to this proposition, but the primary issue centers on the idea that leaders create space by expanding Acceptance, Authority (and accountability) and Ability, hence enhancing change space. We asked interviewees directly whether there was evidence of improvements in these AAA factors (regarding change) after the interventions. Figure 10 shows the proportion of interviewees overall and from each case who perceived improvements in these factors, and we combine them into the change space model introduced earlier, illustrating our belief that change space at the center of the Venn diagram was enhanced in each case (given evidence in Table 40.

\section{Figure 10. Proportion of interviewees perceiving improvements to AAA}

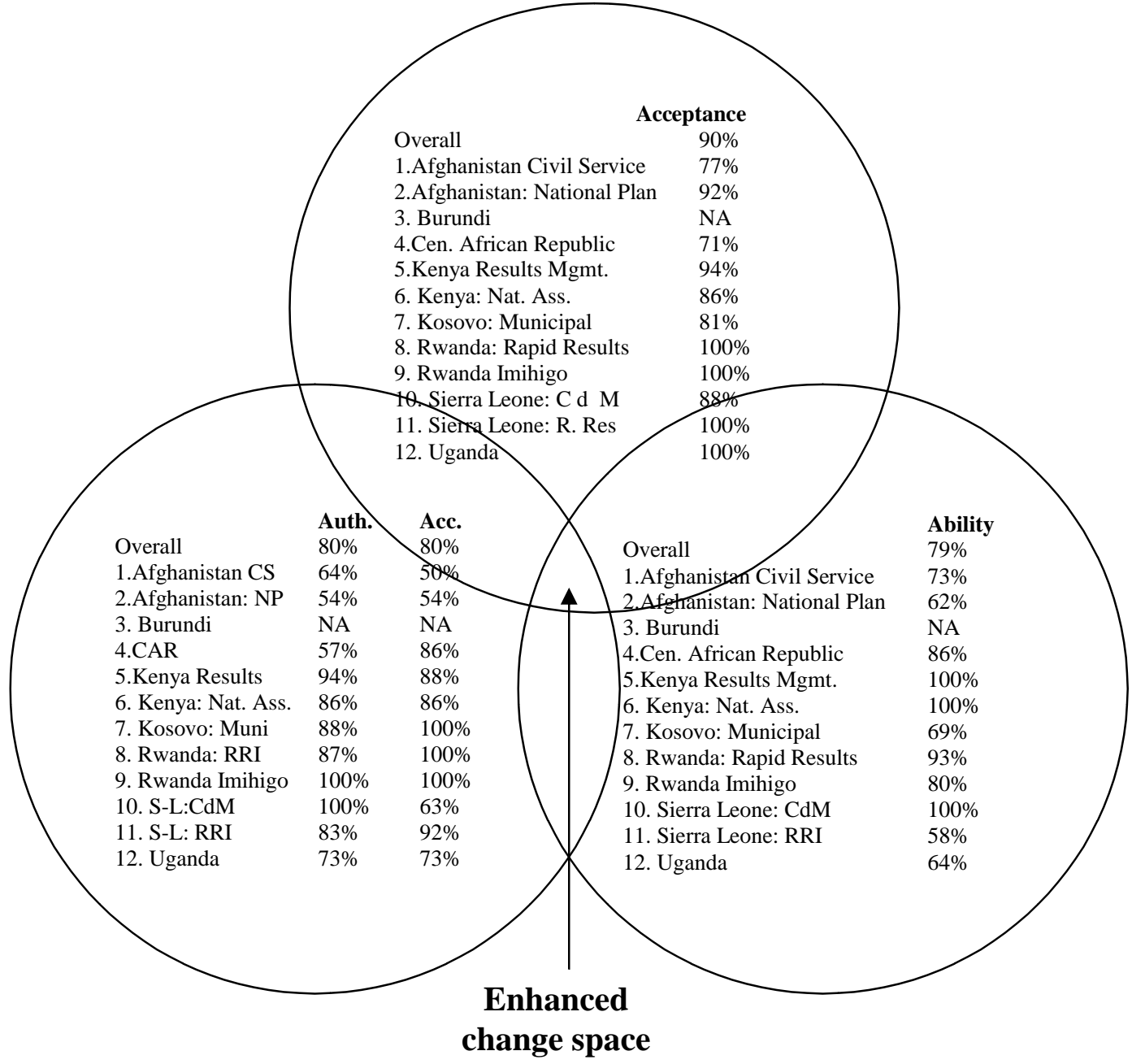


The data in Figure 10 provides basic reference points about the impact leadership may have had on change space in these cases. Even viewed in such limited form, however, one notes some interesting variation. Primarily, we see that more interviewees reflected on improved acceptance than improved authority, accountability or ability (overall and in the majority of cases). Does this suggest that leadership interventions affect acceptance more than authority and ability factors? Or that the interventions were just more focused on building acceptance than adjusting authority and ability profiles? Or, perhaps, that most cases were at points in the change process where acceptance was the major issue?

These questions are difficult to address, but we tried to dig beneath the basic numbers in Figure 10 and access detailed information on what leadership may have done to affect the AAA factors. We discuss this evidence, on what and how leadership seems to have done, by first focusing on Acceptance, then Authority and Accountability, and last Ability.

\section{What and how leadership impacts on Acceptance}

When interviewees noted that acceptance had improved, we asked them to describe what they meant. We analyzed the content of these answers in conjunction with interviewee comments on why they identified their leaders, to better understand what the acceptance improvements were and how leadership might have contributed to such improvements. Comments on acceptance were sorted into two categories, depending on whether they mentioned changes to beliefs or to commitments (the two aspects of acceptance introduced earlier). Where comments mentioned beliefs they were further parsed reflecting (i) belief that there was a problem, (ii) belief about what the problem was, (iii) belief about a solution, and (iv) belief about implementing said solution. Commentary about leadership interventions to improve acceptance were categorized in three ways, depending on whether the noted leadership engagement reflected a (i) transformational, (ii) transactional, or (iii) relational approach (as discussed earlier).

We found much variation across the sample, illustrated in Table 11. Interviewees in all cases mentioned changes in beliefs, for example, but some alluded to more expansive change. Reported change was narrow in the Afghan civil service case, the Central African Republic case and the Sierra Leone Club de Madrid case. Interviewees in the Afghan example only allude to a common belief about there being a problem, and one suggests this as a limit: "Constant dialog has promoted common belief that there is a problem, but not about what the problem is or how to solve it." A similar comment from the Central African Republic held that, "Workshops create consensus on issues but not on the implementation.”

It is interesting to note that these two cases recorded the lowest percentage of respondents stating that acceptance had improved (in Figure 10). They are also two of the three cases in which acceptance apparently did not go beyond discussing belief to mention commitment. Interviewees in eight other cases did mention commitment when discussing acceptance, often connecting the change in belief to extra commitment for action and implementation. This is particularly the case in the rapid results cases (Kenya, Rwanda and Sierra-Leone) where common belief on the problems, solutions and implementation modalities seemed to flow seamlessly into commitment to act. Comments noted that the commitment was cemented in results agreements, across teams, through collective structures and other mechanisms that locked-in the engagement of multiple parties. 
Table 11. How interviewees described improvements in Acceptance

\begin{tabular}{|c|c|c|c|c|c|}
\hline \multirow{2}{*}{$\begin{array}{c}\text { Country/ } \\
\text { Intervention }\end{array}$} & \multicolumn{2}{|c|}{$\begin{array}{l}\text { What improvements in } \\
\text { Acceptance looked like }\end{array}$} & \multicolumn{3}{|c|}{$\begin{array}{l}\text { How leadership appears to have contributed to these } \\
\text { improvements }\end{array}$} \\
\hline & In Belief & In Commitment & Transformational & Transactional & Relational \\
\hline $\begin{array}{l}\text { 1. Afgh. Civil } \\
\text { Service } \\
\text { Leadership }\end{array}$ & $\begin{array}{l}\text { Evidence } \\
\text { only of (i) }\end{array}$ & No evidence & $\begin{array}{c}\text { Key drivers initiated } \\
\text { discussion }\end{array}$ & $\begin{array}{c}\text { Incentives to } \\
\text { engage, learn, } \\
\text { introduce ideas, } \\
\text { hold delegated } \\
\text { discussion } \\
\end{array}$ & $\begin{array}{c}\text { Workshops, } \\
\text { constant dialog, } \\
\text { partnering, outside } \\
\text { ideas via external } \\
\text { relationships } \\
\end{array}$ \\
\hline $\begin{array}{l}\text { 2. Afghan.: } \\
\text { National Plan }\end{array}$ & $\begin{array}{l}\text { Evidence } \\
\text { of (i), } \\
\text { some of } \\
\text { (ii), (iii) }\end{array}$ & $\begin{array}{l}\text { Some evidence } \\
\text { of commitment } \\
\text { to plan }\end{array}$ & $\begin{array}{c}\text { Initiated by inspiring } \\
\text { personality, ideas } \\
\text { person }\end{array}$ & $\begin{array}{c}\text { Delegated planning } \\
\text { authority, Plan } \\
\text { locks in formal } \\
\text { commitment }\end{array}$ & $\begin{array}{c}\text { Discussion, } \\
\text { workshops, team } \\
\text { planning and } \\
\text { visioning } \\
\end{array}$ \\
\hline 3. Burundi & NA & NA & NA & NA & NA \\
\hline $\begin{array}{l}\text { 4. Central } \\
\text { African } \\
\text { Republic }\end{array}$ & $\begin{array}{l}\text { Evidence } \\
\text { of (i) and } \\
\text { some of } \\
\text { (ii) }\end{array}$ & No evidence & $\begin{array}{c}\text { Trusted, neutral } \\
\text { figure attracted } \\
\text { parties, embodied } \\
\text { change message }\end{array}$ & No evidence & $\begin{array}{c}\text { Workshops, } \\
\text { continued meeting } \\
\text { and discussion }\end{array}$ \\
\hline $\begin{array}{l}\text { 5. Kenya } \\
\text { Results Based } \\
\text { Management }\end{array}$ & $\begin{array}{l}\text { Evidence } \\
\text { of (i), (ii), } \\
\text { (iii) and } \\
\text { (iv) }\end{array}$ & $\begin{array}{c}\text { Commitment } \\
\text { across teams, } \\
\text { goals, committed } \\
\text { Inter-Ministerial } \\
\text { forum }\end{array}$ & No evidence & $\begin{array}{l}\text { Results focus, } \\
\text { delegated teams, } \\
\text { time pressure, } \\
\text { Monitoring, } \\
\text { publication }\end{array}$ & $\begin{array}{c}\text { Cross } \\
\text { organizational } \\
\text { teams, Inter- } \\
\text { Ministerial Forums, } \\
\text { Coaching } \\
\end{array}$ \\
\hline $\begin{array}{l}\text { 6. Kenya : } \\
\text { National } \\
\text { Assembly }\end{array}$ & $\begin{array}{l}\text { Evidence } \\
\text { of (i), (ii), } \\
\text { (iii) and } \\
\text { (iv) }\end{array}$ & $\begin{array}{l}\text { Commitment of } \\
\text { multiple parties } \\
\text { to each other and } \\
\text { vision, Clear } \\
\text { roles }\end{array}$ & $\begin{array}{l}\text { Inspirational figure } \\
\text { led process, ideas, } \\
\text { and encouraged } \\
\text { others }\end{array}$ & $\begin{array}{c}\text { New law initiated; } \\
\text { Incentive systems } \\
\text { changed; New law, } \\
\text { structures led the } \\
\text { change }\end{array}$ & $\begin{array}{c}\text { Linkages across } \\
\text { multiple entities, } \\
\text { Supportive public } \\
\text { opinion; Committee } \\
\text { structures }\end{array}$ \\
\hline 7. Kosovo & $\begin{array}{l}\text { Evidence } \\
\text { of (i), (ii), } \\
\text { (iii) and } \\
\text { (iv) }\end{array}$ & $\begin{array}{l}\text { Teams foster } \\
\text { commitment, } \\
\text { new mechanisms } \\
\text { to specify roles }\end{array}$ & $\begin{array}{c}\text { Inspirational } \\
\text { Inspector credited } \\
\text { with initiating, } \\
\text { driving process }\end{array}$ & $\begin{array}{l}\text { Delegation in } \\
\text { teams, mechanisms } \\
\text { to shape behavior } \\
\text { (Code of Ethics) }\end{array}$ & $\begin{array}{l}\text { Team system, Inter- } \\
\text { agency } \\
\text { communication and } \\
\text { implementation }\end{array}$ \\
\hline $\begin{array}{l}\text { 8. Rwanda: } \\
\text { Rapid Results }\end{array}$ & $\begin{array}{l}\text { Evidence } \\
\text { of (i), (ii), } \\
\text { (iii) and } \\
\text { (iv) }\end{array}$ & $\begin{array}{l}\text { Common goal } \\
\text { and commitment } \\
\text { to each other } \\
\text { drives the work ; } \\
\text { Focus on results }\end{array}$ & $\begin{array}{l}\text { One person identified } \\
\text { as a driving force }\end{array}$ & $\begin{array}{l}\text { Mayor delegated } \\
\text { authority, time } \\
\text { pressure, Incentive } \\
\text { to think, together; } \\
\text { results; Collective } \\
\text { responsibility } \\
\end{array}$ & $\begin{array}{c}\text { Community teams, } \\
\text { Internal/external } \\
\text { network } \\
\text { collaboration, } \\
\text { Forums, Coaching }\end{array}$ \\
\hline $\begin{array}{l}\text { 9. Rwanda } \\
\text { Imihigo }\end{array}$ & $\begin{array}{l}\text { Evidence } \\
\text { of (i), (ii), } \\
\text { (iii) and } \\
\text { (iv) }\end{array}$ & $\begin{array}{c}\text { Clear collective } \\
\text { goals and roles } \\
\text { ensure } \\
\text { commitment; } \\
\text { Focus on results }\end{array}$ & $\begin{array}{l}\text { President seen as } \\
\text { visionary in } \\
\text { resurrecting idea and } \\
\text { inspiring creativity }\end{array}$ & $\begin{array}{c}\text { Incentives for } \\
\text { delegated problem } \\
\text { solving, Rewards, } \\
\text { Goals, Monitoring, } \\
\text { Collective structure }\end{array}$ & $\begin{array}{l}\text { Forums, meetings, } \\
\text { Strategy sessions } \\
\text { (partner planning); } \\
\text { Public presentations }\end{array}$ \\
\hline $\begin{array}{c}\text { 10. Sierra } \\
\text { Leone: Club } \\
\text { de Madrid } \\
\end{array}$ & $\begin{array}{l}\text { Evidence } \\
\text { of (i) and } \\
\text { some (ii) }\end{array}$ & No evidence & $\begin{array}{c}\text { One NGO leader } \\
\text { inspired; won office } \\
\text { and inspired others }\end{array}$ & $\begin{array}{c}\text { President allowed } \\
\text { meetings to go } \\
\text { ahead }\end{array}$ & $\begin{array}{c}\text { Open conventions; } \\
\text { Working together in } \\
\text { network }\end{array}$ \\
\hline $\begin{array}{l}\text { 11. Sierra } \\
\text { Leone: Rapid } \\
\text { Results }\end{array}$ & $\begin{array}{l}\text { (i), (ii), } \\
\text { (iii) and } \\
\text { some (iv) }\end{array}$ & $\begin{array}{l}\text { Commitment in } \\
\text { groups }\end{array}$ & No evidence & $\begin{array}{c}\text { Authority to form } \\
\text { delegated teams; } \\
\text { incentives to work } \\
\text { together, results } \\
\text { focus, reviews }\end{array}$ & $\begin{array}{c}\text { Ward consultations, } \\
\text { cross-organizational } \\
\text { working teams, } \\
\text { coaching, review } \\
\text { meetings }\end{array}$ \\
\hline $\begin{array}{l}\text { 12. Uganda: } \\
\text { Leadership } \\
\text { Preparation }\end{array}$ & $\begin{array}{c}\text { Evidence } \\
\text { of (i), (ii), } \\
\text { (iii),(iv) }\end{array}$ & $\begin{array}{l}\text { Vision and } \\
\text { consultative } \\
\text { process locks } \\
\text { commitment in }\end{array}$ & No evidence & $\begin{array}{c}\text { Roles clarified, } \\
\text { delegated } \\
\text { authority, vision, } \\
\text { Consultative } \\
\text { process formalized } \\
\end{array}$ & $\begin{array}{l}\text { Workshops, } \\
\text { monthly meetings, } \\
\text { group planning, } \\
\text { Committee } \\
\text { structures } \\
\end{array}$ \\
\hline
\end{tabular}

Key: In 'Improvements in Belief' section, (i) = common belief that there was a problem, (ii) $=$ common belief about what the problem was, (iii) $=$ common belief about a solution, (iv) $=$ common belief about implementing said solution. 
We also found variation in the types of leadership mechanisms apparently facilitating improved acceptance, although in most cases a mixture of transformational, transactional and relational actions was evident. What we previously termed 'transformational' leadership seems to have played a role in eight of the cases, where high profile individuals were identified as inspiring new beliefs, providing new ideas, 'embodying the message' and encouraging others to think differently. They were central to creating acceptance and commitment to vision, even if they did not develop the vision themselves (rather inspiring others to work through problems or see reality in a different way, as in Kenya's parliamentary case and the role of political leadership in Rwanda).

But transformational leadership was more than matched by transactional leadership activities (which interviewees in all cases noted more often and with more prominence). We placed delegation into this category (even though Bennis calls this 'managing self' and presents it as a transformational leadership action). This is because we noted that leadership facilitates acceptance of change when leadership structures are adjusted (temporarily in many cases) to foster incentive structures associated with delegation. This could mean creating team structures that cross organizations, reporting mechanisms that look flatter than in a typical hierarchy, or introducing participatory planning with a performance focus and time limit (effectively creating an urgency situation and the incentives associated with such). The structures affect incentives which lead to different behaviors, fostering different dialogs, and creating a space in which agents can test beliefs and capacities. Other transactional leadership actions involved clarifying roles, introducing work plans and vision statements into organizations, forcing groups to identify goals and achieve them in allotted time periods, and monitoring achievements (especially to build a case for transition and institutionalization of change). We found that these transactional tools were central to translating belief to commitment (where transactional actions fostered formal and informal mechanisms to 'lock-in' acceptance). Interestingly, we found the transactional tools often centered on creating incentives and opportunities to collaborate and engage around problems, and to lock commitment in through these relationships.

Leadership interventions that fostered relational connection involved other devices as well, including developing teams, holding workshops and facilitating discussion and conversation, introducing coaches to aid engagements and such. These mechanisms were central, we believe, to creating what Heifetz et al. (2009) call the 'holding environment' in which agents investigate, learn about and progress to solve problems. This is made apparent in statements from each case: In the Afghan Civil service case, respondents noted, "Dialog has helped build trust in this discussion" and "If you talk about change management, it means you're involving many people, creating a conducive environment, creating more leaders"; In Afghan's planning case, “Ongoing consultative groups facilitated ongoing discussion"; In the CAR, "Discuss[ions] with others [helped] see the needs more clearly"; An interviewee in Kenya's results case said, "Through interaction we better appreciate difficulties resolving problems” ; A comment from Kenya's parliamentary change reads, "The volume of engagement is evidence of acceptance of the importance of parliament"; A Kosovo interviewee said, "We now approach problems in a team; we understand better, and know our obligations" ; An interview in respect of Rwanda's rapid results initiatives yielded the comment that, "The community agrees on problems, understands they can solve them; Acceptance comes through results, and the 
collaboration of the community in response to challenge"; An interviewee said of Rwanda's Imihigo: "Forums help clarify problems and collective roles in addressing them"; Commentary form Sierra Leone’s Club de Madrid case included, "We held open convention to discuss things; Space has been gradually opened for discussing this; Acceptance comes when you are not doing this in isolation”; In Sierra Leone's rapid results case a respondent noted, "All stakeholders are now involved in a consultative process; Acceptance comes through discussion”; Interviewees from Uganda stated that, "There have been increased discussions around issue" and "There is a greater appreciation for working together.”

We note that at least two respondents in most cases mentioned the importance of these relational mechanisms being 'ongoing', 'continued' or 'persistent' instead of once-off. We infer that these mechanisms are more influential where they foster and support ongoing conversations about change rather than isolated engagements which do not seem effective at building acceptance needed to effect change. Ongoing relational mechanisms also seem to facilitate acceptance best when they allow expanded access over time. This is something we noticed even though our methodology did not allow a proper temporal perspective on when acceptance mattered in the change process or how relational mechanisms might have facilitated acceptance improvement differently over time. Nonetheless, we constructed Figure 11 to try and reflect what we heard about:

(i) Intense, narrow teams and coalitions initially being created to explore problems and solutions in early change stages and ensure common belief and commitment in a core,

(ii) Expansion into broader coalitions and small networks to ensure acceptance for initial interventions (through experimental interventions commonly involving pilots) and,

(iii) Broadening even further as change progresses, to dispersed networks where multiple small teams and coalitions hold acceptance building conversations at various change stages - some focused on identifying problems, others on initiating solutions and others getting acceptance on the costs of institutionalization (for example).

Figure 11. Relational mechanisms and acceptance discussions through the change process

(i) Acceptance in core team

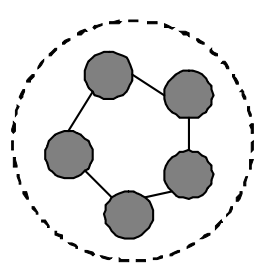

(ii) Acceptance in broader coalition

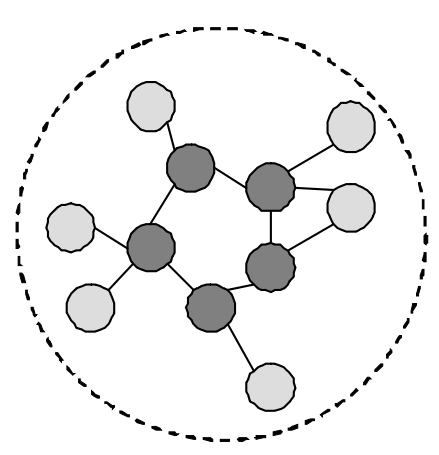

(iii) Acceptance in network

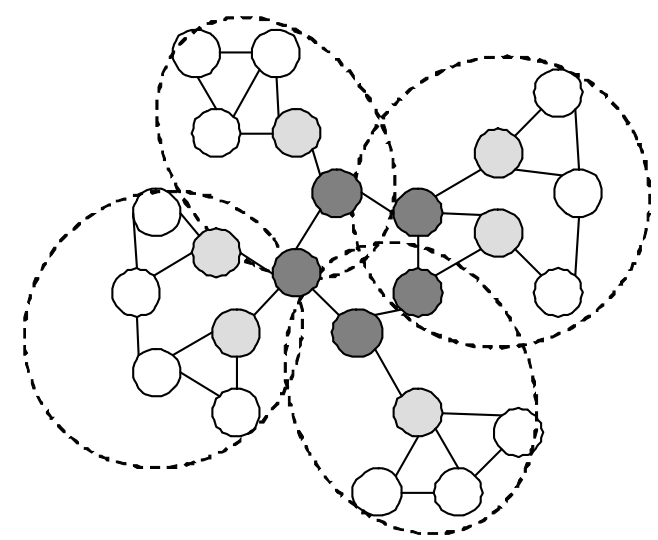

Two acceptance challenges seem to arise as change progresses: more entities need to come to shared belief and commitment (about the basis issues like problems and potential solutions) and new types of belief and commitment are required with key players. The 
former challenge is shown in Figure 11 and described above. The latter involves building acceptance about transition and institutionalization, making change permanent on the basis of initial experiment. These conversations manifest in transactional leadership initiatives-new laws and structures that give permanence to change. We noted that these conversations were extremely difficult and often involved leaders in authority positionsthe Cabinet in Burundi, President in Rwanda, and Parliament in Kenya. Conversations with these entities seem to be facilitated by early results in change experiments (like rapid results engagements), demand pressure (like civil society demands in Kenya), and the influence of connectors who can bridge such parties to the guiding coalition.

These connectors are vital to building acceptance because the relational, transactions and transformational mechanisms we refer to are typically used by different leaders fulfilling different functions in facilitating acceptance improvements. Transformational messages fostering acceptance come from a few individuals but transactional leadership solutions that incentivize learning and commitment often come through others, for example. Coordinating these functions seems a crucial leadership task that we found various interviewees alluded to, in commonly identifying leaders who connected people, helped spread the ideas, attracted important parties to the change process, etc. This 'connector' role is thus vital in facilitating acceptance, especially in fostering relational mechanisms.

We also found that problems were referenced repeatedly as entry points for conversation about change and for fostering new beliefs and acceptance about change, especially in coalitions (which appear to emerge because of common concern about problems). In this regard an interviewee in the Ugandan case stated that, "We have to identify problems first, so we are much more engaged in the weakness first as an entry point." Instances of limited acceptance-like the Afghan civil service case - seem to have been weaker in terms of both the focus on problems and emphasis on relational mechanisms and connectors. One commentator, referring to the rush to train Afghans in Germany, noted that "If you don't know where you're going, you will never get there." Others bemoaned the lack of clear problem identification as a major limit on change and leadership promotion: "No one asked if the problem was about using the capacity we already had"; "The capacity problem was that managers could not absorb what they were being taught”; "The problem was not really training, but building an environment where trained people could work-but this was never considered"; "They never really understood the problem. In my opinion... it needs research. There could be other reasons [for weak capacity]. I was not the designer of this program, so I don't know [why they chose the solution they did]."

\section{What and how leadership impacts on Authority}

The change space approach holds that acceptance is necessary but insufficient to effect change. Authority and Ability must be aligned with Acceptance to create space for adjustment. Figure 10 showed that interviewees perceived improvements in Authority and Ability as well as Acceptance, in all cases. But what did the authority improvements look like and how did leadership potentially contribute to these improvements? We asked these questions explicitly, soliciting stories about how authority had improved and also about how such improvements were matched with leadership activities. Answers for each 
case are summarized in Table 12, which shows how interviewees spoke of 'authority' improvements and how leadership actions connected to such commentaries.

\section{Table 12. How interviewees described improvements in Authority/Accountability}

\begin{tabular}{|c|c|c|c|c|}
\hline \multirow[t]{2}{*}{$\begin{array}{c}\text { Country/ } \\
\text { Intervention }\end{array}$} & \multirow[t]{2}{*}{$\begin{array}{l}\text { What improvements in Authority } \\
\text { looked like }\end{array}$} & \multicolumn{3}{|c|}{$\begin{array}{c}\text { How leadership appears to have contributed to these } \\
\text { improvements }\end{array}$} \\
\hline & & Transformational & Transactional & Relational \\
\hline $\begin{array}{l}\text { 1. Afgh. Civil } \\
\text { Service } \\
\text { Leadership }\end{array}$ & $\begin{array}{l}\text { Authority still monopolized at top; } \\
\text { some delegation; High-level people } \\
\text { vital; Budget certainty; Improved } \\
\text { confidence, understanding of roles }\end{array}$ & $\begin{array}{l}\text { Deputy Minister } \\
\text { used authority to } \\
\text { buffer reform from } \\
\text { political opponents }\end{array}$ & $\begin{array}{l}\text { Budget certainty } \\
\text { allowed; some } \\
\text { delegation; Role } \\
\text { clarity }\end{array}$ & $\begin{array}{l}\text { Workshops, peer } \\
\text { learning, sharing } \\
\text { opportunities for } \\
\text { deputy ministers }\end{array}$ \\
\hline $\begin{array}{l}\text { 2. Afghan.: } \\
\text { National Plan }\end{array}$ & $\begin{array}{l}\text { Authority still centralized to benefit } \\
\text { few, but some confidence; Afghans } \\
\text { lead process; Some delegation; Plan } \\
\text { enhances credibility }\end{array}$ & $\begin{array}{l}\text { Strong mandate } \\
\text { given from top to } \\
\text { develop plan, vision }\end{array}$ & $\begin{array}{l}\text { Delegated } \\
\text { authority to plan, } \\
\text { Team-like } \\
\text { structure }\end{array}$ & $\begin{array}{c}\text { Planning } \\
\text { workshops }\end{array}$ \\
\hline 3. Burundi & $\begin{array}{l}\text { Authority to produce services in } \\
\text { flexible manner was limited to } \\
\text { pilots; de jure and de facto realities } \\
\text { are constrained }\end{array}$ & $\begin{array}{l}\text { New govt. embodies } \\
\text { message of change } \\
\text { and service delivery }\end{array}$ & $\begin{array}{l}\text { Delegate } \\
\text { flexibility, targets, } \\
\text { time limits; 'Hold' } \\
\text { on rules, roles }\end{array}$ & $\begin{array}{l}\text { Workshops; } \\
\text { Plan, working } \\
\text { teams, } \\
\text { Discussions }\end{array}$ \\
\hline $\begin{array}{l}\text { 4. Central } \\
\text { African } \\
\text { Republic }\end{array}$ & $\begin{array}{l}\text { Still limited authority in Govt. } \\
\text { because of limits to respect, but } \\
\text { Committee of Wise Men does lend } \\
\text { some credibility to process }\end{array}$ & $\begin{array}{l}\text { Committee of Wise } \\
\text { Men created to } \\
\text { authorize process }\end{array}$ & Limited evidence & $\begin{array}{l}\text { Workshops } \\
\text { meant to } \\
\text { galvanize } \\
\text { support for govt. }\end{array}$ \\
\hline $\begin{array}{l}\text { 5. Kenya } \\
\text { Results Based } \\
\text { Management }\end{array}$ & $\begin{array}{c}\text { Performance based } \\
\text { authority/accountability; But } \\
\text { limited after pilots; Laws, power } \\
\text { structures remain; Cross-peer teams } \\
\text { more authorized; Work plans } \\
\text { protect from outside interference }\end{array}$ & $\begin{array}{l}\text { President demands } \\
\text { results }\end{array}$ & $\begin{array}{l}\text { Delegate } \\
\text { flexibility, targets, } \\
\text { time limits, } \\
\text { Ministry created, } \\
\text { work plan, roles, } \\
\text { monitoring, Team }\end{array}$ & $\begin{array}{l}\text { Planning and } \\
\text { working teams, } \\
\text { Discussion space } \\
\text { to define } \\
\text { problems and } \\
\text { solutions }\end{array}$ \\
\hline $\begin{array}{l}\text { 6. Kenya : } \\
\text { National } \\
\text { Assembly }\end{array}$ & $\begin{array}{l}\text { President no longer intimidates } \\
\text { MP's; Independence; Access to } \\
\text { resources (people, money); New } \\
\text { legislation; committee system }\end{array}$ & $\begin{array}{c}\text { Parliamentarian } \\
\text { pushed Law, } \\
\text { promoted message } \\
\text { of new Parliament }\end{array}$ & $\begin{array}{l}\text { New laws, new } \\
\text { conditions of } \\
\text { service, control } \\
\text { over resources }\end{array}$ & $\begin{array}{l}\text { Committee } \\
\text { system; } \\
\text { Networked } \\
\text { collaboration }\end{array}$ \\
\hline 7. Ko & $\begin{array}{l}\text { Authority through knowledge, } \\
\text { experience, team structure, new } \\
\text { laws, confidence in discussions }\end{array}$ & $\begin{array}{c}\text { One inspector } \\
\text { encouraged others to } \\
\text { do differently }\end{array}$ & $\begin{array}{l}\text { New laws, team } \\
\text { structure }\end{array}$ & $\begin{array}{l}\text { Team structure, } \\
\text { discussions }\end{array}$ \\
\hline $\begin{array}{l}\text { 8. Rwanda: } \\
\text { Rapid Results }\end{array}$ & $\begin{array}{c}\text { Community owns process, } \\
\text { confidence from responsibility, in } \\
\text { teams through results, self respect, } \\
\text { access to resources }\end{array}$ & $\begin{array}{c}\text { Delegation message } \\
\text { from top authorities } \\
\text { empowered } \\
\text { community } \\
\end{array}$ & $\begin{array}{c}\text { Teams, results } \\
\text { targets, work plan, } \\
\text { monitoring, roles, } \\
\text { delegation } \\
\end{array}$ & $\begin{array}{l}\text { Team structure, } \\
\text { discussion, } \\
\text { connections to } \\
\text { govt., NGOs }\end{array}$ \\
\hline $\begin{array}{l}\text { 9. Rwanda } \\
\text { Imihigo }\end{array}$ & $\begin{array}{l}\text { Performance requirements give } \\
\text { authority to act, ensure } \\
\text { accountability; public meetings } \\
\text { mean broad authorization; Results } \\
\text { expand authority; unity on the goals } \\
\text { gives us authority. }\end{array}$ & $\begin{array}{l}\text { President inspired } \\
\text { the process, giving } \\
\text { authority to Mayors } \\
\text { and holding them } \\
\text { accountable }\end{array}$ & $\begin{array}{l}\text { Performance } \\
\text { requirements, } \\
\text { public meetings, } \\
\text { group decisions } \\
\text { stimulate authority } \\
\text { and accountability }\end{array}$ & $\begin{array}{l}\text { Community } \\
\text { meetings help } \\
\text { build authority } \\
\text { and } \\
\text { accountability }\end{array}$ \\
\hline $\begin{array}{l}\text { 10. Sierra } \\
\text { Leone: Club } \\
\text { de Madrid }\end{array}$ & $\begin{array}{l}\text { Women more in leadership } \\
\text { positions; More participation; } \\
\text { Better knowledge, confidence; } \\
\text { Women working together; } \\
\text { opportunities to run. }\end{array}$ & $\begin{array}{l}\text { Women won office } \\
\text { authorized others }\end{array}$ & $\begin{array}{l}\text { Incentives to run } \\
\text { for office; quotas; } \\
\text { Incentives and } \\
\text { opportunities to } \\
\text { gain knowledge }\end{array}$ & $\begin{array}{l}\text { Public spaces, } \\
\text { share, advocate; } \\
\text { workshop, NGO } \\
\text { connections, } \\
\text { peer connection }\end{array}$ \\
\hline $\begin{array}{l}\text { 11. Sierra } \\
\text { Leone: Rapid } \\
\text { Results }\end{array}$ & $\begin{array}{l}\text { Authority shared with citizens; } \\
\text { Local accountability via mandate; } \\
\text { community watch-dog; But unclear } \\
\text { local power structures; local egos; } \\
\text { elections bring new people }\end{array}$ & No evidence & $\begin{array}{l}\text { Teams, local } \\
\text { government } \\
\text { structures, citizen } \\
\text { mandates, } \\
\text { monitoring }\end{array}$ & $\begin{array}{l}\text { Local teams, } \\
\text { forums, work } \\
\text { commitments in } \\
\text { local } \\
\text { governments }\end{array}$ \\
\hline $\begin{array}{l}\text { 12. Uganda: } \\
\text { Leadership } \\
\text { Preparation }\end{array}$ & $\begin{array}{l}\text { More authorized; Clearer priorities, } \\
\text { clearer authority; Better understand } \\
\text { of roles, responsibility of each } \\
\text { level; More confidence }\end{array}$ & $\begin{array}{l}\text { President's } \\
\text { involvement gave } \\
\text { the intervention } \\
\text { great authority }\end{array}$ & $\begin{array}{l}\text { Clear roles, } \\
\text { prioritized plans, } \\
\text { decision processes }\end{array}$ & $\begin{array}{l}\text { Workshops, } \\
\text { monthly forums, } \\
\text { decision-making } \\
\text { structures }\end{array}$ \\
\hline
\end{tabular}


Interviewees painted pictures of authority adjustment that varied across cases. We found, for example, that most cases had a mixture of formal and informal authority adjustments that facilitated the change process. These included changes to laws and official processes and delegated roles (formal) as well as informal delegation of responsibility and the creation of informal team mechanisms. Adjustments in authority structures tended to create space by enhancing flexibility for agents to identify problems and address these problems. In some cases the flexibility was matched by improved reliability of resource streams (which agents felt made their de jure authority more real because they actually had control over resources). In various cases the flexibility was structured and tied to accountability mechanisms like performance agreements or publication commitments. The blend of such seems to have enhanced perceptions agents had of their own empowerment and role in dealing with problems.

Interviewees in some cases noted that even these changes did not create substantially more authority for agents, however, because of the prevalence of pre-existing political and power structures that seem to be both hierarchical and informal in contexts like Afghanistan, Burundi, and Sierra Leone. We see that these structures were directly addressed in contexts where the authority circle seems to have expanded the most, like Kenya's Parliamentary reform. These contexts also seem different in the degree to which authority structures have been permanently adjusted, with most discussion focused on temporary measures. A number of interviewees in both Afghan cases and all the rapid results cases, for example, noted that authority increased during the intervention but either reverted to normal afterwards or was left in a limbo (where agents did not know if temporary changes to structures would be made permanent). Steps to make new authority structures more permanent were seen in Kosovo, Kenya's Parliamentary case and Uganda, involving changes to formal mechanisms (like laws) as well as real adjustments in informal structures (political communication channels and invitation lists for policy decision-making discussions, for example). Permanent authority adjustments and changes to informal power structured seem vital to allowing change progression through transition to institutionalization, but also seem more demanding on leadership than temporary authorizing activities or those that are more technical.

We found that leadership seemed to impact authority through the three mechanism types already discussed; transformational, transactional and relational. The transformational interventions were again less referenced, but as with acceptance they seem fundamentally important. Top leaders inspired confidence amongst people which enhanced their perceived authority to push boundaries. We also heard of cases where influential leaders used their positions of authority to buffer and protect interventions from political interference. It seems as if such actions give followers confidence and build trust, with agents seeing that the leader is willing to put himself out for something he believes in. It is apparent that transformational actions and moments can help to galvanize support for a change message and draw legitimacy towards a change movement.

The bulk of leadership functions apparently affecting authority were transactional in nature. They involved adjustments to formal and informal structures that shaped incentives, reporting lines, relational connections and such in the organizational contexts we were looking at. They also involved (invariably) leaders in authority positions, who could create teams, introduce performance contracts, allow some flexibility from 
problematic procurement laws or procedures, increase the authority particular agents had over resources, etc. Transactional leaders introduced structures that allowed those under their authority to examine problems, explore solutions and experiment with ideas, often in relationships that did not exist before. These interventions were extraordinaryrequiring leaders to introduce mechanisms quite different from the norm.

Examples include teams that crossed bureaucratic boundaries in Kenya, and Deputy Ministers in Afghanistan who spoke to colleagues in other ministries for (it seems) the first time. (We get the impression that bureaucratic leaders in many of these contexts gain power by controlling how their people communicate outwardly, so delegating such communicating to mid-level teams is a significant adjustment). Being authorized to engage with each other opened the doors for these deputies to share knowledge and ideas and build confidence. The feeling of confidence translated into empowerment where the sharing was tied to real delegation - especially with some kind of accountability backstop like a performance agreement. Technical instruments like work plans and agreements that clarified roles also seem to have given agents authorizing mechanisms to use as buffers against external pressures and to organize internally. We noted that there were some instances where people in positions of authority did not create transactional environments like this, however, and interviewees noted so: "He should have led because he was mandate to-but he did not let go"; "They were in charge and had to allow their staff to attend, but chose not to."

The last comment alludes to the idea of relational engagement once again. We heard a lot about relational mechanisms leaders used to build authority. These were often inspired by the transformational messages already discussed and were facilitated by transactional decisions (with no real examples of people organizing into teams, coalitions or networks without some kind of transactional adjustment allowing and encouraging this). These engagements involved the creation of teams and forums, holding of workshops, facilitation of cross-organizational discussions, etc. A number of interviewees discussed how being involved in these entities fostered knowledge gains that improved their confidence and feeling of empowerment. We also heard of people feeling more confidence simply because they now had access to people who could help them solve problems, or how being in a supportive community made them feel more authorized. Interviewees also reflected on feeling more accountable to their group members, which seems to have promoted public value creation, especially when structures incentivized the groups to pursue such (trumping mechanisms that might have previously encouraged purely private value creation by individuals).

It was the interaction of transformational, transactional and relational leadership that seems to have been most important, however. In Rwanda's rapid results case we heard how the Gashaki community was inspired to take responsibility of its problems when the Mayor delivered an inspirational message that poverty in the village was not something the government could solve; a solution would have to come through the community. The community's authority grew through transactional steps that included building teams and introducing time-bound performance requirements that forced the community to take authority of their situation. Key authority figures in this process included the Executive Secretary and locally elected team leaders. Team structures in the community, regular forums to discuss results, and connections to NGOs outside of the village were facilitated 
by coaches and proved valuable in galvanizing perceptions that the community was indeed authorized to identify and solve their problems - and ensuring community members held each other accountable for doing so. This group-based authority manifest in the community replacing an ineffective Executive Secretary and developing new proactive channels of engaging with the Mayor of Musanze, two developments one would arguably see irregularly in patrimonial systems. Coaches and the Executive Secretary played the connector roles in much of this case, helping coordinate between parties needing more authority (the community) and those in a position to enhance authority (like the Mayor, or NGOs). As in the discussion of acceptance, the connector seemed vital in most cases-ensuring that agents not in positions of authority could tie up with those in authority positions.

\section{What and how leadership impacts on Ability}

It is interesting to note that interviewees mentioned core abilities as key influences on both acceptance and authority: Some described acceptance improvements coming because of improved abilities, and others noted that confidence grew as abilities grew. Table 13 shows comments interviewees made about ability improvements themselves.

Table13. How interviewees described improvements in Ability

\begin{tabular}{|c|c|c|c|c|}
\hline \multirow[t]{2}{*}{$\begin{array}{c}\text { Country/ } \\
\text { Intervention }\end{array}$} & \multirow[t]{2}{*}{$\begin{array}{l}\text { What improvements in } \\
\text { Ability looked like }\end{array}$} & \multicolumn{3}{|c|}{$\begin{array}{l}\text { How leadership appears to have contributed to these } \\
\text { improvements }\end{array}$} \\
\hline & & Transformational & Transactional & Relational \\
\hline $\begin{array}{l}\text { 1. Afgh. } \\
\text { Civil Service } \\
\text { Leadership }\end{array}$ & $\begin{array}{l}\text { More money, infrastructure, } \\
\text { skills, information. But } \\
\text { strings, no depth, no } \\
\text { prioritization. }\end{array}$ & No evidence & $\begin{array}{c}\text { Donor processes, } \\
\text { incentives to create } \\
\text { and share information }\end{array}$ & Sharing of information \\
\hline $\begin{array}{l}\text { 2. Afghan.: } \\
\text { Nat.Plan }\end{array}$ & $\begin{array}{c}\text { More money, skills, } \\
\text { information. But no priorities }\end{array}$ & No evidence & $\begin{array}{c}\text { Planning process } \\
\text { developed }\end{array}$ & Sharing information \\
\hline 3. Burundi & NA & NA & NA & NA \\
\hline 4. CAR & $\begin{array}{l}\text { More information but other } \\
\text { abilities limited }\end{array}$ & No evidence & No evidence & $\begin{array}{l}\text { Participation in } \\
\text { workshops }\end{array}$ \\
\hline $\begin{array}{l}\text { 5. Kenya } \\
\text { Results }\end{array}$ & $\begin{array}{l}\text { More money, skills, } \\
\text { information }\end{array}$ & No evidence & $\begin{array}{l}\text { Results incentives, } \\
\text { time limit, work plan, } \\
\text { public rewards }\end{array}$ & $\begin{array}{c}\text { Team structures, cross- } \\
\text { organizational } \\
\text { engagements } \\
\end{array}$ \\
\hline $\begin{array}{l}\text { 6. Kenya : } \\
\text { National } \\
\text { Assembly }\end{array}$ & $\begin{array}{l}\text { Moe money, skills and } \\
\text { people, information }\end{array}$ & $\begin{array}{l}\text { Idea champion, } \\
\text { fought for more } \\
\text { money }\end{array}$ & $\begin{array}{l}\text { Committee structure, } \\
\text { conditions of service, } \\
\text { fiscal independence }\end{array}$ & $\begin{array}{l}\text { Network connections } \\
\text { to civil society, } \\
\text { committees }\end{array}$ \\
\hline 7. Kosovo & $\begin{array}{c}\text { Some say improved finances, } \\
\text { others not, but better skills } \\
\text { and information }\end{array}$ & $\begin{array}{l}\text { Lead inspector was } \\
\text { an idea champion }\end{array}$ & $\begin{array}{l}\text { Laws, Code of ethics, } \\
\text { Conditions of service } \\
\text { (overtime rules, etc.) }\end{array}$ & $\begin{array}{c}\text { Inspectors engage in } \\
\text { forum, learning } \\
\text { lessons, external ideas } \\
\end{array}$ \\
\hline $\begin{array}{l}\text { 8. Rwanda: } \\
\text { Rapid } \\
\text { Results }\end{array}$ & $\begin{array}{l}\text { Locally accessed money, } \\
\text { skills, information. Slow } \\
\text { process of accumulation. }\end{array}$ & $\begin{array}{l}\text { Encouragement } \\
\text { from mayor }\end{array}$ & $\begin{array}{l}\text { Public work program, } \\
\text { results incentives, } \\
\text { time limit, workplans }\end{array}$ & $\begin{array}{c}\text { Team learning, } \\
\text { network, tap skills in } \\
\text { groups, coach connects }\end{array}$ \\
\hline $\begin{array}{l}\text { 9. Rwanda } \\
\text { Imihigo }\end{array}$ & $\begin{array}{l}\text { More skills, information. } \\
\text { Finances still limited. }\end{array}$ & $\begin{array}{l}\text { President inspired } \\
\text { creativity; Minister } \\
\text { was idea champion } \\
\end{array}$ & $\begin{array}{l}\text { Results drive, better } \\
\text { specialization, } \\
\text { prioritization. } \\
\end{array}$ & $\begin{array}{c}\text { Shared responsibilities, } \\
\text { network connections, } \\
\text { mobilized resources }\end{array}$ \\
\hline $\begin{array}{l}\text { 10. Sierra } \\
\text { Leone: Club } \\
\text { de Madrid }\end{array}$ & $\begin{array}{c}\text { Some skills, information } \\
\text { improvement, and ability to } \\
\text { communicate. }\end{array}$ & $\begin{array}{l}\text { External messages; } \\
\text { Lessons from } \\
\text { successful women }\end{array}$ & $\begin{array}{l}\text { Training, quotas at } \\
\text { the local level }\end{array}$ & $\begin{array}{l}\text { Workshops, advocacy } \\
\text { in communities, peer } \\
\text { learning }\end{array}$ \\
\hline $\begin{array}{l}\text { 11. Sierra } \\
\text { Leone: } \\
\text { Results }\end{array}$ & $\begin{array}{c}\text { Some money, skills, } \\
\text { information. But still limited } \\
\text { people, finances. }\end{array}$ & No evidence & $\begin{array}{l}\text { Incentives to learn, } \\
\text { publication required, } \\
\text { results, time limits }\end{array}$ & $\begin{array}{l}\text { Teams to learn, build } \\
\text { knowledge, network } \\
\text { connections }\end{array}$ \\
\hline $\begin{array}{l}\text { 12. Uganda: } \\
\text { Leadership } \\
\text { Preparation }\end{array}$ & Better skills, information & $\begin{array}{l}\text { Inspiration from } \\
\text { outside parties who } \\
\text { show it can work }\end{array}$ & $\begin{array}{l}\text { Access to info. act, } \\
\text { process streamlined, } \\
\text { prioritization process }\end{array}$ & $\begin{array}{l}\text { Peer learning, sharing } \\
\text { in forums, meetings }\end{array}$ \\
\hline
\end{tabular}


Interviewees in all cases mentioned that abilities had been enhanced since the intervention we were looking at. In some cases the mix of improved abilities included money, people and skills, and information. In other cases interviewees did not feel one or more of these abilities was improved. The more interesting variation came in how the improvements were described and explained, and how these tied to descriptions of new leadership actions. Some interviewees spoke of abilities being enhanced through agents having more incentive, freedom and encouragement to explore extant but latent abilities. Others spoke of abilities being enhanced through connections made to new parties, internal and external to the context, that could augment existing financial, human resource and informational abilities. Improvements were not always unequivocal 'goods' however, especially in the latter set of experiences.

The first type of ability improvement was described in a variety of cases, including all the rapid results interventions, Rwanda’s Imihigo and Uganda's government transition case. We heard in these cases that agents across ministries, communities and levels of government were encouraged to explore problems and find solutions to problems, within existing ability profiles. The message agents were given here was not that they had insufficient abilities but that they were not properly focusing their abilities on addressing their biggest problems and achieving their most important goals. Leadership seems to have created what Heifetz et al. call holding environments in these settings, where parties that seldom engaged could engage and learn about the abilities that might emerge through creative connections or structured delegation. These environments were facilitated by a mix of transformational messages encouraging agents to stretch themselves, transactional leadership that created appropriate incentive mechanisms, and relational leadership actions that helped foster and energize team, coalition and network building and learning. New ability profiles emerged from such environments:

- Villagers in Gashaki learned that they could accomplish a wide variety of tasks when working with their neighbors and using creative approaches to solve problems. Coaches helped coordinate the different parties to ensure the right mix of abilities was present at the right time, sometimes connecting villagers to outside parties (like NGOs) who were already in the vicinity but whose capacities had never before been accessed (or were underused).

- Ministry of Education officials in Burundi learned that textbook delivery did not necessarily mean acquiring new abilities (vehicular infrastructure, for example) but that connections to Parliamentarians and local government officials led to creative solutions using latent abilities (members of parliament and local officials could transport textbooks to the localities). Once again, coaches helped to connect parties together and ensure lessons were learned that could then be acted upon.

- Kenya's parliament expanded its role substantially in the last decade, creating functional committees to analyze laws, budgets and such. While Parliamentarians do undergo training in such work and small support staffs have been established, the key to new analytical abilities comes through connections with civil society organizations that do this work anyway (Lawyers and Economics Associations, for example). The network connections to these organizations were facilitated by a few important connectors commonly identified in interviews. 
We would argue that leadership itself was a latent ability that emerged in these cases, as was learning. Agents and organizations with latent abilities found new functional roles associated with new functional requirements, and found new ways of learning about their problems and capacities to really effect change. Team leaders in Gashaki play roles mobilizing community members that they never did before, while local officials in Burundi now play delivery roles they did not before, and civil society organizations in Kenya have crucial roles to play in providing information to Parliament-a function they could always do but which was heretofore under-explored and under-demanded. The community, ministry and parliament/civil society groups found ways of learning about problems and solutions that ensured a match to their capacity to act-a vital ability.

New functional 'leaders' also emerged as outside augmenters of ability, however. This included donor organizations, government agencies and projects and sometimes NGOs who helped change processes by providing money, technical assistance, and information. Ministries of Finance, civil service agencies and procurement organizations were also identified as 'leaders' that allowed improved access to resources in a way that freed agents to explore change. These kinds of entities were often identified as leaders - in a functional sense-for doing so. Five interviewees across three cases noted that their influence over resources also made them the de-facto key authorizing agents central to change. While these roles are obviously very important we were concerned at emerging problems with such 'leadership' roles because of the turf wars that they seemed to foster (in Afghanistan, for example) and the way external parties seem to attach strings to all new ability enhancing actions. We heard from at least ten interviewees that while there was more money, for example, the list of priorities was so expanded in the process of getting this money to undermine its additive effect.

Externally sourced abilities did not always involve money, however, but also came in the form of information sharing in settings like Uganda and Sierra Leone (where Club de Madrid brings former heads of state to advocate for and expanded role for women in government). Officials from other countries shared experience with in-country peers in these cases (and Kenya's Parliament), helping expand their knowledge and build their informational abilities. These engagements had elements of both transformational and relational leadership because the outside parties introduced inspirational and encouraging messages (as in Sierra Leone) and could also broker new meetings and relationships in the countries (in Kenya, for example, and Uganda) on the basis of their messages. In Uganda, for example, Canadian officials noted the importance of holding policy decisions that involve different levels of officials, which resulted in an expansion of the policy-making terrain through new meeting structures that accommodated new players.

\section{Conclusions on leadership's 'what' and 'how'}

The influence of leadership from external peers goes beyond introducing new information, however. Interviewees in Sierra-Leone noted how having female heads of state from western countries saying "it can be done" enhanced feelings of acceptance and authority, "Opening the eyes of women to believe they should be in the mainstream of politics" and "helping us assert what we want, why, and how to go about it." We believe that change space is created when Acceptance, Authority and Ability are influenced by 
leadership, making the connection between these types of comments and the discussions on these three factors particularly important.

All three change factors are sometimes influenced by one leadership intervention-as in the peer engagement in Sierra Leone noted above. We found that it was more common to see different leaders fulfilling different functions related to different factors in the change space model, however (and found that even where one act influenced all three it needed augmentation from others). The different functions included substantive contributions to task (like providing ideas, procedural contributions like facilitating discussion and providing incentives) and maintenance contributions (accommodating relational links). We found multiple individuals and organizations fulfilled these different functions, expanding change space, through varying mixes of transformational, transactional and relational leadership mechanisms. Connectors played vital roles coordinating across the different functional 'leaders' ensuring that acceptance, authority and ability impacts reinforced each other and ultimately intersected to create space. Examples include:

- We saw leadership interventions that spurred acceptance for new service delivery approaches in all rapid results cases, for example, which were matched with transactional and relational leadership engagements that fostered structures and connections (giving team's authority to pursue creative service delivery options and the ability to implement such). Coaches helped to coordinate the leadership interventions needed to build acceptance, authority and ability.

- Kenya's parliamentary reform was initiated by leaders who encouraged acceptance of a new parliamentary role and simultaneously ensured there was authority to pursue such role (on the basis of new laws). Other leaders emerged to give substance to the newly accepted and authorized vision by connecting members in parliament to the civil society community where abilities could be found. Acceptance was matched with authority and ability to create space for change.

Different gaps seem to exist in different cases, however, providing examples where space was not created even though some leadership was evident:

- The rapid results cases seemed to build acceptance for a new way of delivering services, especially in the delivery teams. But some interviewees noted that temporary improvements in authority were not made permanent and this undermined continued change: "It has to do with authority and resources and legality aspects, all of which are very unclear or conflicted; authority is still very vague and undermines ability.” The leadership gap in these cases seems to center on authority demands when change moves from early experiments (pilots in initiation) to the point of transition and institutionalization beyond such pilots.

- The Afghan civil service case provided an example of leadership interventions that were perhaps not well founded on a process of effective acceptance building. The 21 interviewees suggested about 15 different versions of the capacity problem in Afghanistan and many did not think the intervention we were examining addressed the core problem. Leadership here introduced new resources, but did not authorize a process in which groups could explore problems and build acceptance.

We believe that the discussions above suggest that acts of transformational, transactional and relational leadership can indeed build change space by impacting on Acceptance, Authority and Ability profiles. We present this basic argument graphically in Figure 12 
reflecting observations that change was facilitated (through leadership acts) when these three factors intersected, and limited where such intersection was limited (as in the examples). We hold further that the evidence suggests space is most effectively created when leadership acts facilitate openness and learning, often attracting agents to address problems in groups. This reflects well on our proposition:

- Leadership contributes to change when it builds change space-where leaders foster acceptance for change, grant authority to change (with accountability), and introduce or free the abilities necessary to achieve change. Change space is especially enhanced where leadership facilitates open access societies and learning organizations in which members are empowered - in groups - to pursue change through problem solving.

Figure 12. Leadership creates change space by stimulating A,A,A

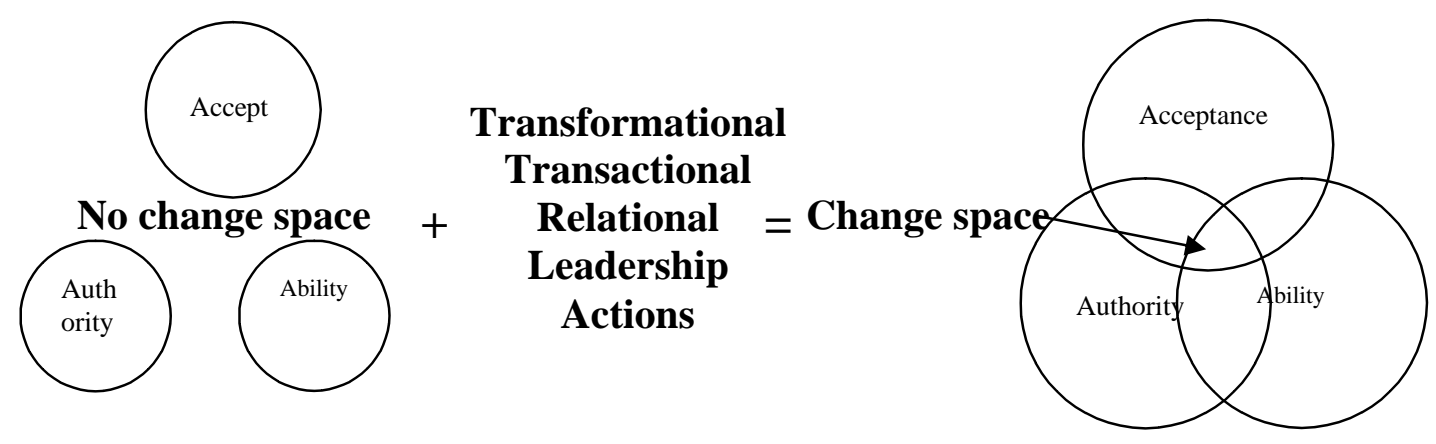

\section{Leadership and context}

Our research cases covered many contexts, even though they were commonly centered on noticeable change events in developing countries emerging from some form of fragility. Afghanistan is very different from Kenya, or Kosovo. Central government reform in Uganda happens in a different context to community empowerment in Rwanda or local government development in Sierra Leone. As discussed earlier, one might have expected leadership-led change to look different across these different contexts, reflecting these differences. Grindle and Thomas (1997) would say the political economy context should foster different leadership solutions, while Lewin (1951) would expect differences because of differences in the 'force field' of driving and limiting factors.

And we do find differences. Discussing Table 3, we noted that interviewee bias seemed to reflect differences in the nature of the interventions we studied. In Table 4 we showed that the perceptions of change and leadership improvement varied across cases, seemingly reflecting differences in the problems being addressed, the stage of change already achieved, and other contextual factors. Figure 8 illustrated that interviewees identified different sets of 'leaders' engaged in the change process, in different domains: In some cases (like Uganda) the leaders were mostly in the public domain but in others (like Kenya's parliamentary reform) they were in the public and issue domain.

But the differences are trumped by similarities in what leadership-led change looks like in these very different contexts. In all cases we found multiple leaders identified, functionality seen as the dominant basis of this identification, and mixes of transformational, transactional and relational leadership actions seen to impact change 
when intersecting to create space-generally for groups to solve problems. We thus believe that there is value in our proposition about context and leadership-led change:

- Leadership manifests in different ways in different contexts, depending on contextual readiness and factors that shape change and leadership opportunities; but the key characteristics of plurality, functionality, problem orientation and change space creation are likely to be common to all successful leadership-led change events.

The proposition reflects both an understanding that leadership looks different in different places and a firm belief that leadership-led change has some common characteristics: Top-down leadership by lone individuals may be prevalent in some contexts but will not by itself effect change; "Leadership by edict" will not effect change; Leadership as authority alone will not effect change; Leadership as inspiration alone will not effect change. Where change emerges from leadership, it involves over time many different 'leaders' fulfilling different functions and building space to solve problems. We believe that change is so seldom successful because, at least in part, this type of leadership is seldom emphasized and practiced.

And in the research we identified contextual factors that might promote or limit such leadership, especially in development contexts. We learned of these when asking interviewees directly about the influence of political and economic conditions on leadership before and after the focal interventions. Comments led us to identify what we call 'contextual readiness' and 'contextual shaping' factors that influenced whether leadership-led change emerged and what it looked like. We list some of these in Table 14, labeled as driving or limiting factors (a la Lewin).

Table 14. Driving and limiting contextual issues affecting readiness and shape

\begin{tabular}{|c|c|c|}
\hline & $\begin{array}{l}\text { Affecting contextual readiness for } \\
\text { leadership-led change }\end{array}$ & $\begin{array}{l}\text { Affecting contextual shaping of } \\
\text { leadership-led change }\end{array}$ \\
\hline Driving factors & $\begin{array}{c}\text { Growth in demand for effective } \\
\text { government (esp. by civil society); } \\
\text { Emergent crises; Political prioritization; } \\
\text { Limitation awareness; Growing coalitions } \\
\text { of supporters; Shocks that create urgency; } \\
\text { Facilitating events creating opportunity; } \\
\text { Common concern over specific problems; } \\
\text { Appetite for risk and experimentation; } \\
\text { Neighbor effects }\end{array}$ & $\begin{array}{l}\text { The change domain; Nature of } \\
\text { intervention; Nature of problem; Results } \\
\text { demand continued attention; Expanded } \\
\text { engagement of powerful parties; Evolving } \\
\text { and favorable prioritization of change } \\
\text { agenda; Appetite for engagement and } \\
\text { openness (esp. political); Real-time } \\
\text { responses to constraints esp. authority and } \\
\text { ability requirements) }\end{array}$ \\
\hline $\begin{array}{l}\text { Limiting } \\
\text { factors }\end{array}$ & $\begin{array}{l}\text { Fragmented agendas (prioritization } \\
\text { failures); Satisfaction with routine } \\
\text { solutions instead of problem focus; } \\
\text { conflicting politics; Excessive top-down } \\
\text { authority and narrow power structures } \\
\text { (extremely narrow elites); Incentives to } \\
\text { pursue private rather than public value in } \\
\text { governments; limited demand for } \\
\text { effective governance }\end{array}$ & $\begin{array}{l}\text { Rush to solutions; Un-prioritized agendas } \\
\text { that fragment leadership; Excessive top- } \\
\text { down authority and authorization } \\
\text { structures; Excessive Risk aversion; } \\
\text { Entrenched interests not engaged in change } \\
\text { process; Misaligned incentive mechanisms } \\
\text { (especially promoting private value } \\
\text { creation over public in the public domain); } \\
\text { Social and political status quo protection } \\
\text { mechanisms; Reluctance to learn }\end{array}$ \\
\hline
\end{tabular}


The factors we list will hardly surprise readers, especially those affecting contextual readiness. We found these factors emerged as interviewees discussed both the evolutionary path towards focal interventions and the episodic shock that seemed to stir agents to action. In the case of Kenya's parliamentary reform, for example, we heard that the intervention emerged after a decade of developments in civil society (where the appetite for change was provoked and an understanding of a new parliamentary role was established). A growing coalition inside and outside parliament grew in this period, reflected in the promotion of new laws in the late 1990s. The decade-long move toward change was provoked by adjustments in neighbor countries (noticeably Uganda) which stimulated and informed the Kenyan coalition. The weakening of the Moi administration created opportunities for reform in the late 1990s and the new laws introduced by a group of "young turks" provided the shock that made change an urgent priority. The parliamentary strengthening work that had been tabled for an entire decade finally found its right moment for implementation.

Similar stories emerged across the other cases. The resolution of conflict in Afghanistan only made other problems more apparent, including the need to develop state structures. It took development partners three years to agree that capacity building was a priority in the extremely over-burdened context, however. The need for local inspection bodies to have codes of ethics and such emerged a few years into the decentralization process where officials started worrying that their solution to corruption (inspection) may not have been a solution but a problem. Coalitions had developed around this problem realization within the inspection community itself, and the engagement with Partners for Democratic Change allowed the opportunity for change. Uganda had just been through an election in which opposition parties participated for the first time. A multi-party

government would be in place and this created urgency to adjust policy-making and other bureaucratic structures.

\section{Some general lessons}

From these and other experiences we gleam the general lesson that contexts are not always ready for the type of leadership we believe leads change. And factors that do facilitate such leadership emerge both consistently along long term paths and episodically in the form of change events-shocks or opportunities.

A similar lesson emerges about how factors that drive and limit change shape the leadership-led change itself. Figure 8 showed that leaders fall into different domains in different contexts, for example, which we interpret as the result of (inter alia) the domain of the problem being addressed. Beyond this, we found that some contexts were more flexible than others and accommodated the move from change initiation to transition more readily (through development of new laws, for example). In contrast, excessive topdown controls proved limiting on change in other contexts-like the rapid results stories in Sierra Leone mentioned earlier. In Uganda we found that power-sharing agreements in the political and bureaucratic domains seem to have driven continued change and allowed interventions to mature into more institutionalized, opened policy mechanisms (like cabinet committees, policy groupings, etc.). In Afghanistan, Central African Republic and Sierra Leone, interviewees noted that established power structures continued to thwart change even after the interventions, which affected the 'shape' of resulting leadership structures and the amount of change space created. 
As with driving and limiting factors affecting contextual readiness, we believe these factors influence the costs of exercising leadership that leads change. Where contextual factors make it too costly to either initiate change or to ensure it is sustained, leadership will be lacking. Where contextual factors make it less costly or allow cost sharing across a team, coalition or network, such leadership will be more apparent (Andrews 2008b). In all cases, we hold that leadership will manifest to reflect the tensions between driving and limiting factors, but that change that fosters development will emerge only from leadership that involves many different 'leaders' fulfilling different functions and building space to solve problems, empower communities and foster public value creation.

\section{Conclusions, and a case for more leadership work in development}

We are aware that this paper covers a lot of ground, vast literatures and thick data from complex cases. Our core message in the paper is simple, however: We believe development is all about change, change requires space, space can be created through leadership and the kind of leadership that leads change has peculiar characteristics.

We have presented our arguments in support of such belief, simplified into propositions:

- Leadership is more about groups than individuals, given that there are likely to be multiple people exercising leadership in any successful change event.

- 'Leaders' are identified more because of their functional contribution to change than their personal traits or authority (and the 'connecting' function stands out).

- Leadership contributes to change when it builds change space-where leaders foster acceptance for change, grant authority to change (with accountability), and introduce or free the abilities necessary to achieve change. Change space is especially enhanced where leadership facilitates open access societies and learning organizations in which members are empowered-in groups - to pursue change through problem solving.

- Leadership manifests in different ways in different contexts, depending on contextual readiness and factors that shape change and leadership opportunities; but the key characteristics of plurality, functionality, problem orientation and change space creation are likely to be common to all successful leadership-led change events.

We examined a set of interesting cases of change and leadership in fragile countries to see if these propositions make basic sense. We believe evidence suggests they do. Regardless of the different contexts, and of presumed biases in the sample, we find change in all cases, multiplicity of leaders identified because of function not form in all cases, and leadership impacts on acceptance, authority and ability seemingly facilitating change in all cases.

Our arguments and evidence are presented in the interests of sparking more discussion and research on leadership and change in the development process. Our research approach can be significantly improved upon to provide more convincing results, address more specific questions about leadership, and promote knowledge of this subject even further. We hope this paper sparks just such research. In the mean-time, we believe the paper endorses the attention groups like the Global Leadership Initiative (GLI) have placed on leadership in the development process and the practical work some entities are doing in this area. It is apparent that development interventions should focus more on 
'how' change occurs and what role leadership plays in this 'how'. We recommend that the following ideas should drive such shift in focus:

- Leadership is a key to effecting change and promoting development.

- Leadership interventions should focus on building functional groups of leaders-in teams, coalitions and networks - around unifying problems.

- Leadership interventions should always be focused on creating change space rather than creating leaders as an end.

- Leadership interventions must be fitted to context but consistently emphasize leadership plurality, functionality, problem orientation and change space creation. 


\section{Annex 1. Five stages in the change process: A simple model}

Figure A2.1 shows a simple process model, which involves 5 stages:

- Pre-conceptualization involves establishing readiness and acceptance for change, by destabilizing the status quo, identifying and communicating the need for change, creating a sense of urgency to change, and building guiding teams and coalitions around this need and urgency.

- Conceptualization integrates ideas about creating acceptance over a change vision and planning change, through transforming need to vision (via diagnosis, experimentation, scanning, identification with role models, or active participative enquiry where change agents and targets work together to think about the future-a version of self discovery), communicating the vision, and creating authorizing structures that allow the creation of teams and coalitions (and perhaps even broader networks) around the vision.

- Initiation sees change agents and targets instigating change through early adoption mechanisms like piloting (often through trial and error), empowering experiments by change targets (via flexible authorizing mechanisms and targeted resource facilitation that establish new abilities), providing quick-wins to enhance acceptance of the vision with internal and external stakeholders, facilitating learning and response to unexpected outcomes, and expanding teams, coalitions and network connections to facilitate expanded reach of the change ideas.

- Transition captures the period where new change ideas, processes and such are starting to spread and replace old ideas and processes. There is expanded roll-out and reach in the change process, continued empowerment of a larger set of change targets to implement change, an emphasis on providing quick wins to enhance acceptance of the vision and the costs of implementation (which are usually widespread and threatening) and facilitate sustained momentum for change, consolidation of new authority structures across broader networks and ongoing learning and response to unexpected outcomes.

- Institutionalization is the final stage in the process, where the change becomes the de factor reality, through reinforcement of the new ideas, processes, etc. (in formalized authorizing mechanisms, organizational narratives and ability profiles, for example), measurement of results (particularly against the needs identified as a reason for change), and refinement of the change.

Figure A2.1. Simplified psychological and learning journeys for change targets

\begin{tabular}{|c|c|c|c|c|}
\hline \multirow{3}{*}{$\begin{array}{l}\text { Change stages } \\
\text { Psychological } \\
\text { issues for } \\
\text { change targets } \\
\text { (and strategic } \\
\text { behaviors) }\end{array}$} & Pre-conceptualization & Conceptualization & Transition & Institutionalization \\
\hline & $\begin{array}{l}\text { Skepticism/Cynicism/Denial } \\
\text { /Resistance }\end{array}$ & \multicolumn{2}{|l|}{ Exploration } & Commitment \\
\hline & Anticipation/Confirmation & Culmination & & Aftermath \\
\hline $\begin{array}{c}\text { Learning } \\
\text { dimensions }\end{array}$ & $\begin{array}{l}\text { Unlearning and frame } \\
\text { braking }\end{array}$ & Cognitive re-definitior & & $\begin{array}{l}\text { Personal and relational } \\
\text { refreezing }\end{array}$ \\
\hline
\end{tabular}

Source: Adapted from Andrews (2008) and Armenakis and Bedeian (1999). 
The simplified figure builds on Isabella (1990) and Jaffe et al. (1994) to show that change targets are often initially skeptical and cynical about change, and refuse to believe that it is necessary or will be implemented. In order to manage these emotions, individuals engage in anticipative and confirmatory behaviors—assembling information about change and creating a frame through which to make sense of the proposed change. The result is often resistance to change, underscored by fear. Effective learning strategies can, however, mitigate this resistance-especially if a strategy of unlearning and frame breaking is pursued. This involves producing disconfirming information about the status quo, often via problem or inquiry oriented diagnostic interventions, facilitating "survival anxiety" (where change targets feel that failure to change will induce personal or group failure) and allowing change targets "psychological safety" to overcome learning anxiety and denial of disconfirming data (Schein 1996).

If targets pass beyond this early stage, they are likely to begin exploring new behaviors to test their effectiveness in facilitating personal and organizational success. What Isabella (1990) calls culmination results from a comparison of conditions before and after this new event, which will cause change targets to amend their frame of reference to either include or omit new information. The literature on organizational learning aptly calls such stage "cognitive re-definition" in which new learning is facilitated through "trial and error", scanning the environment, identification with role models, conversational processes and continuous inquiry-based diagnosis. Learning is further fostered through establishing and managing creative tensions, building shared vision and facilitating feedback. As with the first stage, it is important to maintaining "psychological safety" for change targets to allow this learning.

Effective "cognitive re-definition" can help change targets to progress to the final stage, where they commit to the change after they review and evaluate its consequences (what Isabella calls aftermath). Schein (1996) sees this as the final stage in learning as well, where targets test the fit of solutions to the personal and relational context (ensuring that it does not contradict or conflict with surviving personalities, power structures and norms). The learning at this stage needs to also ensure that change has met its needs, both instrumentally and in regard to the cultural, normative and political context in which the organization must work. 


\section{Annex 2. 'Who' were identified as leaders (number of references in parentheses)}

\begin{tabular}{|c|c|c|}
\hline Country/ Intervention & Leaders list preceding intervention & Leaders list post intervention \\
\hline $\begin{array}{l}\text { 1. Afghanistan Civil } \\
\text { Service Leadership (06- } \\
\text { 08) }\end{array}$ & $\begin{array}{l}\text { Civil Service Commission (8); The UNDP (6); } \\
\text { The Vice President Responsible (Armin } \\
\text { Arsala) (3); The World Bank (2); Dr. } \\
\text { Hamidzada, the effective head of the Civil } \\
\text { Service Commission (2) ; Head of UNDP } \\
\text { (Marina Walter); The Afghan Government }\end{array}$ & $\begin{array}{l}\text { Civil Service Commission (8); All Deputy Ministers } \\
\text { across line ministries (though unequal) (4); UNDP } \\
\text { (4); The Independent Directorate of Local } \\
\text { Governance (2); Civil Service Institute (2); Ministry } \\
\text { of Finance (3); Ministry of Rural Development; } \\
\text { Ministry of Justice; Ministry of Urban } \\
\text { Development; Ministry of Economy ; Ministry of } \\
\text { Women's Affairs, Ministry of Education; Ministry } \\
\text { of Labor and Social Affairs; ADB; USAID; World } \\
\text { Bank; European Community; Japan; Dr. Mushahid, } \\
\text { Chairman of the Civil Service Commission; The } \\
\text { President and his close circle of advisers }\end{array}$ \\
\hline $\begin{array}{l}\text { 2. Afghanistan: } \\
\text { Towards a National } \\
\text { Plan (2002) }\end{array}$ & $\begin{array}{l}\text { Attorney General (6), World Bank (2), The } \\
\text { Minister (2), The Deputy Minister (2), } \\
\text { Ministry of Public Health (2), MRRD, MoF, } \\
\text { IMF, United Nations, Asian Development } \\
\text { Bank, Deputy President Arsala, Telecom } \\
\text { Ministry, Brahimi of UN, Government, Dr } \\
\text { Farhang, Dr Abdula, President Karzai }\end{array}$ & $\begin{array}{l}\text { MRRD (3); Government (2); CDC's in Villages; } \\
\text { MoF; Ministry of Telecoms; World Bank; United } \\
\text { States Government; Agha Khan Foundation; UN } \\
\text { Habitat; Sanaee Development Foundation; MoPH }\end{array}$ \\
\hline 3. Burundi (07-09) & NA & NA \\
\hline $\begin{array}{l}\text { 4. Central African } \\
\text { Republic (04-05) }\end{array}$ & $\begin{array}{l}\text { The church leader - 'Zikoi' (2); Minister of } \\
\text { Planning; Prime Minister; World Bank; } \\
\text { Former President of Burundi who helped } \\
\text { organize the workshop; Government }\end{array}$ & $\begin{array}{l}\text { Society generally; There are many in different } \\
\text { departments ; Presidents of local parties ; Rebel } \\
\text { parties not currently engaged ; Parliament }\end{array}$ \\
\hline $\begin{array}{l}\text { 5. Kenya Results Based } \\
\text { Management (04-09) }\end{array}$ & $\begin{array}{l}\text { Government as a whole (4); The Public Sector } \\
\text { Reform Secretariat (2); The head of the public } \\
\text { service; Cabinet; Civil society; UN; DFID; } \\
\text { Canada; Swedes; Kenya private sector } \\
\text { network;media owners association; The } \\
\text { Ministerial Stakeholders Forum; Institute of } \\
\text { Personnel Management (in private sector); } \\
\text { Central Planning Unit; People responsible for } \\
\text { service delivery across ministries; } \\
\text { Development partners; Employers in the } \\
\text { public sector; Workhouse organizations } \\
\text { involved in dealing with the issue; Central } \\
\text { Organization of Training Institutions; } \\
\text { Federation of Kenyan Employers; the National } \\
\text { Industrial Training Body; Public Sector } \\
\text { Management as a whole } \\
\end{array}$ & $\begin{array}{l}\text { Reform Secretariat (3); Permanent Secretaries in } \\
\text { relevant ministries (2); People appointed to manage } \\
\text { teams (2); Kenya Private Sector Alliance (2); } \\
\text { Political leaders(2); Head of State (2); Public } \\
\text { servants; Ministers of Departments; Councilors; } \\
\text { Pensioners (service recipients); Media Owners } \\
\text { Association; Editor's Guild; Head of Public Service ; } \\
\text { People in lower cadres of bureaucracy now } \\
\text { involved; Institute of Personnel Management; } \\
\text { Teams; Procurement entities; Inspectorates; } \\
\text { Employers in affected service delivery entities; } \\
\text { Industry owners receiving services; Civil servants } \\
\text { generally }\end{array}$ \\
\hline $\begin{array}{l}\text { 6. Kenya : National } \\
\text { Assembly (00-09) }\end{array}$ & $\begin{array}{c}\text { USAID (2); Civil society; Centre for } \\
\text { Governance and Development; Institute of } \\
\text { Economic Affairs; SUNY team working for } \\
\text { USAID; Parliament as a whole; Betty Maina; } \\
\text { Nancy Gitau; Waceke Wachira; Peter Oloo- } \\
\text { Aringo (prominent Parliamentarian); Young } \\
\text { turks in Parliament in late 1990s } \\
\end{array}$ & $\begin{array}{l}\text { The Speaker of the House (2); Head Clerks in the } \\
\text { Parliament (2); Parliamentary Initiative Network; } \\
\text { ICJ; The Law Society of Kenya; SUNY; The } \\
\text { Institute of Economic Affairs; Kenya Private Sector } \\
\text { Alliance; Federation of Women Lawyers; USAID }\end{array}$ \\
\hline $\begin{array}{l}\text { 7. Kosovo: Municipal } \\
\text { Anti- Corruption (04- } \\
\text { 06) }\end{array}$ & Director of Inspectors (9); Partners (8) & $\begin{array}{l}\text { Partners (4); The Inspectorates (3); The Mayor (2); } \\
\text { Director of Inspectors in Suhareka; Director of } \\
\text { Inspectors in Rahovec; Former director in Peja; } \\
\text { Director of Podujeva; Head of the Municipality; } \\
\text { Local government; Central Government }\end{array}$ \\
\hline $\begin{array}{l}\text { 8. Rwanda: Rapid } \\
\text { Results (07-09) }\end{array}$ & $\begin{array}{l}\text { Team in general (4); Team leaders (3); Mayor } \\
\text { (2); Executive Secretary (2); MINALOC (2); } \\
\text { World Bank and other donors; HIDA; } \\
\text { university admin; Coach; Government at all } \\
\text { levels; Rector at University }\end{array}$ & $\begin{array}{l}\text { Executive Secretary at sector (7); Mayors (3); } \\
\text { District Authorities (3); MINALOC (2); Ministers; } \\
\text { President; VUP; World Bank; Gatsebo Vice Mayor } \\
\text { in charge of social affairs; Coach; Leaders in the } \\
\text { villages; village and sector authorities; donors; other } \\
\text { government programmes and departments; Teams; } \\
\text { Minister of Local Government; minister of state for } \\
\text { education; University Administration } \\
\end{array}$ \\
\hline $\begin{array}{l}\text { 9. Rwanda Imihigo(07- } \\
\text { 09) }\end{array}$ & $\begin{array}{l}\text { Joint Action Forum (3); President Kagame (3); } \\
\text { Minister of Finance; Minister of Local } \\
\text { Government; Each sector has its own leaders; }\end{array}$ & $\begin{array}{l}\text { Mayors (3); Government in general (2); Local level } \\
\text { citizens in general; Intra-Health ; Elected leaders ; } \\
\text { NGOs ; District leadership through teams; }\end{array}$ \\
\hline
\end{tabular}




\begin{tabular}{|c|c|c|}
\hline & $\begin{array}{l}\text { Ministry of Local Government; Rwanda } \\
\text { Cooperation; World Bank; UNDP; } \\
\text { Government leadership as a whole }\end{array}$ & $\begin{array}{c}\text { President; Minister of Local Government; Prime } \\
\text { Minster; Rwandan leadership in general; Joint } \\
\text { Action Forum; District heads; Ombudsmen and } \\
\text { directors } \\
\end{array}$ \\
\hline $\begin{array}{l}\text { 10. Sierra Leone: Club } \\
\text { de Madrid (2007) }\end{array}$ & $\begin{array}{c}\text { 50/50 Group (4); Campaign for Good } \\
\text { Governance (3); Specific civil society leader } \\
\text { (named); NDI; Parliament }\end{array}$ & $\begin{array}{l}\text { President; Civil society, Many women's groups; } \\
\text { 50/50; CGG; Female parliamentarians in general }\end{array}$ \\
\hline $\begin{array}{l}\text { 11. Sierra Leone: Rapid } \\
\text { Results (04-09) }\end{array}$ & $\begin{array}{l}\text { Decentralization Secretariat (5); The team } \\
\text { leader (2); Local councils (2); Central } \\
\text { technical team; World Bank; IRCBP; } \\
\text { Community people }\end{array}$ & $\begin{array}{l}\text { Chairpersons (2); Mayors (2); The team member } \\
\text { who is now an MP (2);Local level councilors; } \\
\text { Professionals; central level ministry heads; technical } \\
\text { facilitators; local authorities; politicians; community } \\
\text { members (2); Local government; Decentralization } \\
\text { Scretariat; World Bank; EU; Chief Administrators } \\
\text { of Councils; Coaches; Councils as a whole }\end{array}$ \\
\hline $\begin{array}{l}\text { 12. Uganda: Leadership } \\
\text { Preparation for a } \\
\text { Government Transition } \\
(06-07)\end{array}$ & $\begin{array}{l}\text { Cabinet (5); Head of Public Service (3); } \\
\text { Cabinet Secretariat (2); Prime Minister; } \\
\text { President; political leadership (identified as } \\
\text { separate from cabinet and permanent } \\
\text { secretaries) }\end{array}$ & $\begin{array}{l}\text { Cabinet (5); President (5); Permanent Secretaries } \\
\text { (4); Prime Minister (2); Political leadership } \\
\text { generally (identified as separate from cabinet and } \\
\text { permanent secretaries); Parliament; Public servants } \\
\text { (broadly); Minister of Public Service; Vice } \\
\text { President; Head of Public Service; Minister of the } \\
\text { President; IPAC; Cabinet Secretariat. }\end{array}$ \\
\hline
\end{tabular}




\section{References (incomplete)}

Akgün, A.E., Byrne, J.C., Lynn, G.S, and Keskin, H. (2007). Organizational Unlearning as Changes in Beliefs and Routines in Organizations. Journal of Organizational Change Management vol.20(6): 794-812.

Andrews, M. (2008). The Good Governance Agenda. Beyond Indicators Without Theory. Oxford Development Studies.

Archer, D. and Cameron, A. (2008). Collaborative Leadership: How to Succeed in an Interconnected World. New York: Butterworth Heinemann.

Argyris, C. (1990). Overcoming Organizational Defenses: Facilitating Organizational Learning. Boston: Allyn and Bacon.

Armenakis, A.A., and Bedeian, A.G. (1999). Organizational Change: A Review of Theory and Research in the 1990s. Journal of Management vol.25: 293-315.

Armenakis, A.A. and Harris, S.G. (2002). Crafting a Change Message to Create Transformational Readiness. Journal of Organizational Change Management vol.15: 169-183.

Armenakis, A.A., Harris, S.G., and Feild, H.S. (1999). Making Change Permanent: a Model for Institutionalizing Change Interventions. In Passmore, W.A. and Woodman, R.W (eds.) Research in Organizational Change and Development vol. 12: 97-128. Stamford, CT: JAI Press.

Armenakis, A.A., Harris, S.G., and Mossholder, K.W. (1993). Creating Readiness for Organizational Change. Human Relations vol.46: 681-704.

Balkundi, P. and Kilduff, M. (2006). The Ties that Lead: A Social Network Approach to Leadership. The Leadership Quarterly. Vol.17: 419-439.

Bandura, A. (1986). Social Foundations of Thought and Action: A Social Cognitive Theory. Englewood Ciffs, NJ: Prentice-Hall.

Bass, B.M. (1990). Bass and Stogdill's Handbook of Leadership: Theory, Research and Managerial Application. ( $3^{\text {rd }}$ ed.). New York: The Free Press.

Buchanan, D., Claydon, T., and Doyle, M. (1999). Organization Development and Change: the Legacy of the Nineties. Human Resource Management vol.9: 20-37.

Buchanan, D., Fitzgerald, L., Ketley, D., Gollop, R., Jones, J.L., Lamont, S.S., Neath, A., and Whitby, E. (2005). No Going Back: A Review of the Literature on Sustaining Organizational Change. International Journal of Management Reviews vol.7 (3): 189205.

Burke, W.W. (1992). Organizational development: A Process of Learning and Changing. Reading, MA: Addison-Wesley.

Burke, W.W. (2002). Organization Change: Theory and Practice. Thousand Oaks, CA: Sage Publications.

Burnes, B. (2004). Managing Change. London: FT/Prentice Hall.

Burns, J.M. (1978). Leadership. New York: Harper and Row Publishers. 
Cartwright, S. and Schoenberg, R. (2006). Thirty Years of Mergers and Acquisitions Research: Recent Advances and Future Opportunities. British Journal of Management vol.17: S1-S5.

Cinite, I., Duxbury, L.E., and Higgins, C. (2009). Measurement of Perceived Organizational Readiness for Change in the Public Sector. British Journal of Management vol.20: 265-277.

Carlyle, T. (1841). On Heroes, Hero-Worship, and the Heroic History. Boston, MA: Houghton Mifflin.

Cummings, T.G. and Worley, C.G. (2001). Organizational Development and Change $\left(7^{\text {th }}\right.$ ed.). Cincinnati: South-Western College Publishing.

Damanpour, F. (1991). Organizational Innovation: A Meta-analysis of Effects of Determinants and Moderators. Academy of Management Journal vol. 34: 555-590.

DiMaggio, P.J. and Powell, W.W. (1983). The Iron Cage Revisited: Institutional Isomorphism and Collective Rationality in Organizational Fields. American Sociological Review vol 48: 147-160.

Doyle, M., Claydon, T. and Buchanan, D. (2000). Mixed Results, Lousy Process: Contrasts and Contradictions in the Management Experience of Change. British Journal of Management vol.11: 59-80.

Drazen, A. and Grilli, V. (1990). The Benefits and Costs of Economic Reform. NBER Working Paper 3527. Cambridge, MA: NBER.

Eldredge, N. and Gould, S.J. (1972). Punctuated Equilibria: An Alternative to Phyletic Gradualism. In T.J.M. Schopf, ed., Models in Paleobiology. San Francisco: Freeman Cooper: 82-115.

Fernandez, S. (2005). Developing and Testing an Integrative Framework of Public Sector Leadership: Evidence from the Public Education Arena. Journal of Public Administration, Research and Theory vol.15: 197-217.

Fernandez, S. and Pitts, D.W. (2007). Under What Conditions do Public Managers Favor and Pursue Organizational Change? The American Review of Public Administration vol.37: 324-341.

Fernandez, S. and Rainey, H. (2006). Managing Successful Organizational Change in the Public Sector. Public Administration Review (March/April): 168-176.

Galpin, T. 1996. The Human Side of Change: A Practical Guide to Organizational Redesign. San Francisco: Jossey Bass.

Gemmill,G. and Smith, C.A. (1985). Dissipative Structure Model for Organization Transformation. Human Relations vol. 38(8): 751-66.

Gilley, A. (2005). The Manager as Change Leader. Westport, CT: Prager.

Gilley, A., Dixon, P. and Gilley, J.W. (2008). Characteristics of Leadership Effectiveness: Implementing Change and Driving Change in Organizations. Human Resource Development Quarterly vol.19 (2): 153-169. 
Greiner, L. (1972). Evolution and Revolution as Organizations Grow. Harvard Business Review vol.50 (4): 37-46.

Hackman, J.R. and Walton, R.E. (1986). Leading Groups in Organizations. In Goodman, P.S. (ed.). Designing Effective Work Groups: 72-119. San Francisco: Jossey-Bass.

Hannan, M.T., and Freeman, J. (1984). Structural Inertia and Organizational Change. American Sociological Review vol.8: 929-964.

Haveman, H. (1992). Between a Rock and a Hard Place: Organizational Change and Performance Under Conditions of Fundamental Environmental Transformation. Administrative Science Quarterly vol. 37: 48-75.

Heifetz, R. (1994). Leadership without Easy Answers. Cambridge, MA: Harvard University Press.

Hennessey, J.T. (1998). “Reinventing” Government: Does Leadership Make a Difference? Public Administration Review vol.58: 322-332.

Isabella, L. (1990). Evolving Interpretations as a Change Unfolds: How Managers Construe Key Organizational Events. Academy of Management Journal vol. 33: 7-41. Jaffe, D.T., Scott, C.D., and Tobe, G.R. (1994). How to Revitalize Yourself, Your Work, and Your Organization: Rekindling Commitment. San Francisco: Jossey-Bass.

Judson, A.S. (1991). Changing Behavior in Organizations: Minimizing Resistance to Change. Cambridge, MA.: Blackwell Business.

Kanter, R.M. (1983). The Change Masters. New York: Simon \& Schuster.

Kanter, R.M., Stein, B.A., and Jick, T.D. (1992). The Challenge of Organizational Change. New York: Free Press.

Kelman, S. (2005). Unleashing Change: A Study of Organizational Renewal in Government. Washington, D.C.: Brookings.

Ketts de Vries, M.F.R and Balazs, K. (1999). Transforming the Mind-set of the Organization. Administration and Society vol.30(6): 640-75.

Kotter, J.P. (1995). Leading Change: Why Transformation Efforts Fail. Harvard Business Review vol.73: 59-67.

Kouzes, J., and Posner, B. (2007). The Leadership Challenge. California: Jossey Bass.

Lawrence, P.R., and Lorsch, J.W. (1967). Organization and Environment: Managing

Differentiation and Integration. Boston: Harvard University, Graduate School of

Business Administration.

Lewin, K. (1947). Frontiers in Group Dynamics. Human Relations vol.1: 5-41.

Lewin, K. (ed.). (1951). Field Theory in Social Science: Selected Theoretical Papers by Kurt Lewin. London: Tavistock.

Linsky, M. and Heifetz, R.A. (2002). Leadership on the Line: Staying Alive Through the Dangers of Leading. Cambridge, MA: Harvard University Press. 
Lora, E. and Barrera, F. (1997). A Decade of Structural Reforms in Latin America: Growth, Productivity and Investment and Not What They Used to Be. Working Paper 350. Washington, D.C., United States: Inter-American Development Bank, Office of the Chief Economist.

Lora, E. and Panizza, U. (2002). Structural Reforms Under Scrutiny. Research Department Working Paper 470. Washington, D.C., United States: Inter-American Development Bank..

Löwestedt, J. (1993) Organizing Frameworks in Emerging Organizations: A Cognitive Approach to the Analysis of Change. Human Relations vol.46: 501-526.

McCall, M.W. Jr. and Lombardo, M.M. (1983). Off the Track: Why and How Successful Executives Get Derailed. Greenboro, NC: Centre for Creative Leadership.

Matta, N. and Ashkenas, R.N. 2003. Why Good Projects Fail Anyway. Harvard Business review (September).

Medley, B.C. and Akan, O.H. (2008). Creating Positive Change in Community Organizations. Nonprofit Management and Leadership vol.18(4): 485-496.

Meyer, A., Brooks, G., and Goes, J. (1990). Environmental Jolts and Industry Revolutions: Organizational Responses to Discontinuous Change. Strategic Management Journal vol.11: 93-110.

Meyer, A., Brooks, G., and Goes, J. (1990). Environmental Jolts and Industry Revolutions: Organizational Responses to Discontinuous Change. Strategic Management Journal vol.11: 93-110.

Miles, R. and Snow, C. (1978). Organizational Strategy, Structure, and Process. New York: McGraw-Hill.

Nadler, D.A. and Nadler, M.B. (1998). Champions of Change: How CEOs and Their Companies Are Mastering the Skills of Radical Change. San Francisco: Jossey-Bass.

NHS Modernization Agency. (2002). Improvement Leaders' Guide to Sustainability and Spread. Ipswich: Ancient House Printing Group.

North, D.C. (1990). Institutions, Organizational Change and Economic Performance. New York: Cambridge University Press.

Nutt, P. (1986). Tactics of Implementation. Academy of Management Journal vol.29 (2): 230-61.

Orlikowski, W. (1996). Improving Organizational Transformation Over Time: A Situated Change Perspective. Information Systems Research vol.7: 63-92.

Peters, T. and Waterman, R. H. (1982). In Search of Excellence: Lessons from America's Best-Run Companies. London: Harper and Row.

Pettigrew, A. M. (1997). What is a Processual Analysis? Scandinavian Journal of Management, 13 (40): 337-48.

Pettigrew, A.M. (2000). Linking Change Processes and Outcomes: A Commentary on Ghosal, Bartless and Weick. In Beer, M. and Nhona, N (eds.) Breaking the Code of Change. Boston: Harvard Business School Press. 
Pfeffer, J. (1992). Managing with Power: Politics and Influence in Organizations. Boston, MA: Harvard Business School Press.

Pfeffer, J., and Salancik, G.R. (1978). The External Control of Organizations. New York: Harper and Row.

Pierson, P. (2004). Politics in Time: History, Institutions and Social Analysis. Princeton: Princeton University Press.

Pritchett, L and Woolcock, M. (2004) Solutions When the Solution is the Problem: Arraying the Disarray in Development. World Development, vol.32 (2):191-212.

Rimmer, M., MacNeil, J., Chenhall, R., Langfield-Smith, K., and Watts, L. (1996). Reinventing Competitiveness: Achieving Best Practice in Australia. South Melbourne, Australia: Pitman.

Rodrik, D. (ed.). (2003). In Search of Prosperity: Analytic Narratives on Economic Growth. Princeton, NJ: Princeton University Press.

Sastry, M. (1997). Problems and Paradoxes in a Model of Punctuated Equilibrium Change. Administrative Science Quarterly vol. 42: 237-275.

Schein, E.H. (1996). Kurt Lewin's Change Theory in the Field and in the Classroom: Notes toward a Model of Managed Learning. Systems Practice Vol.9: 27-47.

Scott, W.R. (2003). Organizations: Rational, Natural and Open Systems ( $^{\text {th }}$ ed.). Upper Saddle River, NJ: Prentice Hall.

Senge, P.M, Klenier, A., Roberts, C., Ross, R., Roth, G., and Smith, B. (1999). The Dance of Change: The Challenges of Sustaining Momentum in Learning Organizations. New York: Currency/Doubleday.

Torres, L. (2004). Trajectories in Public Administration Reforms in European Continental Countries. Australian Journal of Public Administration vol. 63(3): 99-112.

Van de Ven, A.H. and Huber, G. (1990). Longitudinal Field Research Methods for Studying Processes of Organizational Change. Organization Science vol.1: 213-219.

Van de Ven, A.H. and Poole, M.S. (1995). Explaining Development and Change in Organizations. Academy of Management Review vol.20: 510-540.

Waclawski, J. (2002). Large-scale Organizational Change and Performance: an Empirical Examination. Human Resource Development Quarterly 13 (3): 289-305.

Walker, H.J., Armenakis, A.A., and Bernerth, J.B. (2007). Factors Influencing Organizational Change Efforts. Journal of Organizational Change Management vol. 20(6): 761-773.

Washington, M. and Hacker, M. (2005). Why Change Fails: Knowledge Counts. Leadership and Organizational Development Journal vol.26: 400-411.

Weick, K.E. and Quinn, R.E. (1999). Organizational Change and Development. Annual Review of Psychology vol.50: 361-386.

Wilson, J.Q. (2002). Bureaucracy. New York: Basic Books. 
Woolsey Biggart, N. and Guillen, M.F. (1999). Developing Difference: Social Organization and the Rise of the Auto Industries of South Korea, Taiwan, Spain and Argentina. American Sociological Review, Vol. 64 (5): 722-747.

Yukl, G. (2002). Leadership in Organizations (5 ${ }^{\text {th }}$ ed.). Uppr Saddle, NJ.: Prentice Hall.

Zaccaro, S.J., Rittman, A.L. and Marks, M.A. (2001). Team Leadership. The Leadership Quarterly vol.12(4): 451-483.

\footnotetext{
${ }^{\mathrm{i}}$ Pritchett and Woolcock (2004) discusses such problem in this domain.

ii See Andrews $(2008,2008)$ for an example of this discussion.

iii Consider Lora and Barrera (1997) and Lora and Panizza (2002) discussing Latin America’s experience.

iv This is a key part of the storyline in Pritchett and Woolcock (2004), Andrews (2008, 2008a) and Lora and Panizza (2002): Change is not only limited by weak implementation of reform solutions.

${ }^{\mathrm{v}}$ The Global Leadership Initiative Sponsored this research.

${ }^{v i}$ For other recent studies, see also Waclawski (2002), Washington and Hacker (2005) and Cartwright and Schoenberg (2006).

vii See Buchanan et al. (1999) and Doyle et al. (2000) as examples. Also consider Kotter (1995, 59) who recalls his observations of change efforts: "A few ... have been very successful. A few have been utter failures. Most fall somewhere in between, with a distinct tilt toward the lower end of the scale."

viii Consider the variation in titles of just a few schools of thought on the subject: "Planned change" (Lewin 1947), the "Culture-Excellence" approach (Peters and Waterman 1982, Kanter 1989), "Postmodernism" (Pfeffer 1992) and "Processualist" (Pettigrew 1997).

${ }^{\text {ix }}$ See, in particular Armenakis and Bedeian (1999) and Walker, Armenakis and Bernerth (2007).

${ }^{\mathrm{x}}$ To name just a few: Griffin (1974) used this term in analyzing change emerging from the green revolution in agriculture, Grindle and Thomas (1991) apply it in looking at reform in developing countries, Golembiewski (1969) and Wilson (1989) speak of the challenge of enacting reforms in complex political environments, and Ilchman and Uphoff (1997 but originally published in 1969) are perhaps most direct in calling their book on the topic, The Political Economy of Change.

${ }^{x i}$ Mahoney (2000), North (1990) and Pierson (2004) are examples.

xii Often between internal and external factors and often revealing some organizational deficiency requiring attention (in focus, structure, staffing, external alignment, etc.).

xiii For more thorough discussion, see Burnes (2004), Cummings and Worley (2001); Medley and Akan (2008); Pettigrew (2000) and Weick and Quinn (1999).

xiv Just as some biological evolution scholars connect theories of gradualism and punctuated equilibrium, suggesting that change may happen in both ways and the latter may be a special case of the former (Eldredge and Gould 1972). In organizational theory Greiner (1972) speaks of both evolution and revolution in the change processes and Meyer, Brooks, and Goes (1990) show empirically that both change types have occurred in the context of a set of hospitals, which underwent continuous , evolutionary adjustment in the 1960s (gradually adding services) but radical episodic change in the 1970s (because of mounting costs). See also discussions by Fernandez (2004) and Weick and Quinn (1999).

${ }^{x v}$ Organizations and societies do not always perish (at least not in the short run), but we argue that the failure to adjust relegates some organizations and societies to low trajectory development paths characterized by weak growth, malaise and repeated tension that may emerge in patterns of self destruction (conflict).

xvi Senge et al. $(1999,10)$ speak about 'the dance of change' between growth and limiting processes that ultimately impacts how much and what kind of change is possible. Buchanan et al. $(2005,193)$ allude to Lewin's 'force field' concept "in which driving and resisting forces determine whether and to what extent change takes place." Other authors refer to a myriad of factors organizations have to navigate around the facilitate change (see articles like Damanpour 1991; Gresov et al. 1993; Haveman 1992; Meyer et al. 1990; Miles and Snow 1978 and Sastry 1997).

xvii In their political economy perspective, Grindle and Thomas (1991) argue that the "room to maneuver" is central to progressive policy making (and that elites manage to survive largely because they enjoy such
} 
room while others do not). Woolsey-Biggart and Guillen $(1999,726)$ note that the "organizing logics" of different countries create different 'opportunity spaces' for industrial development that "allow firms and other economic actors to pursue some activities...more successfully than others.” Hausmann and Rodrik (2006, 31) suggest that economic growth emerges when governments allow "potential areas of attention [to] evolve" by "creating [a] space" for such.

xviii As well as Armenakis, Harris and Mossholder (1993); Buchanan et al. (2005); Cinite, Duxbury and Higgins (2009); Eby et al. (2000); Kotter (1995); Lehman, Greener and Simpson (2002); Lewin (1951); Pettigrew et al. (1992); Senge et al. (1999); Van de Ven and Poole (1995); Weick and Quinn (1999). xix Interestingly, while both kinds of acceptance seem necessary to create space for change the literature emphasizes informal acceptance (beliefs) as more important-indeed arguing that beliefs are the gateway to commitment (Walker, Armenakis and Bernerth 2007). This runs counter to the way acceptance is dealt with in many development interventions, where formal commitment mechanisms are emphasized.

${ }^{\mathrm{xx}}$ As with beliefs and commitment, both types of authority can facilitate change, but the literature shows a biased emphasis towards informal structures as the de facto authorizing mechanism in many settings. Again one can contrast this with the often-formal approach to thinking about authorization and accountability structures in development interventions.

${ }^{x x i}$ We draw from various authors in noting the need for these factors to overlap and create change space. Cinite, Duxbury and Higgins $(2009,265)$ discuss the importance of three similar "sub-constructs" overlapping when examining readiness for change in Canadian public sector organizations: "commitment...to change" (Acceptance), "support" for change (authority), and "competence of change agents" (ability). Armenakis, Harris and Mossholder 1993, 681) imply necessary AAA overlap in defining perceived organizational readiness for change (PORC) as, “[O]rganizational members' beliefs, attitudes, and intentions regarding the extent to which changes are needed [acceptance] and the organization's capacity to successfully make those changes [ability and, arguably also authority].” Fernandez $(2004,200)$ notes that leadership manifests in such space, where they receive "strong political support [authority], [are] provided with ample resources [ability], and [are] assigned a task that match[es] their skills and abilities [acceptance].”

xxii In keeping with the double loop learning approach made famous by Chris Argyris (see Argyris 1990) which centered on the idea that organizations need to integrate learning into their permanent structures to create space for adjustment to dynamic environmental change.

xxiii This follows thinking in de Mesquita et al. (2003) and in Grindle and Thomas (1993) and echoes Ilchman and Uphoff's definition of politics (1997, xxii-xxiii) as encompassing "all those activities and attitudes that affect in some way the acquisition, influence and exercise of authority."

xxiv See North's (1995) discussion of open access societies to see how inclusionary authority structures are commonly seen to facilitate more effective adaptive responses to external pressures for change.

${ }^{x x v}$ Particularly Armenakis and Bedian (1999), Armenakis and Harris (2002), Armenakis, Harris and Field (1999), Burke (2002), Galpin (1996), Gemmill and Smith (1985), Judson (1991), Kotter (1995), and Medley and Akan (2008).

${ }^{x x v i}$ See Bray (1994), Cobb et al. (1995), Clarke et al. (1996) and Lora and Panizza (2002) who all discuss the important human element in change.

xxvii Including Akgün et al. (2007), Argyris (1990), Armenakis and Bedeian (1999), Bandura (1986), Isabella (1990), Jaffe, Scott and Tobe (1994), Löwstedt (1993), Schein (1996), and Senge (1992). Lewin (1947) himself introduced the idea of action learning as central to organizational change, and Senge et al. (1999) tout the importance of having learning define the organizations.

xxviii See Dawson (1994), Kanter et al. (1992) and Pfeffer (1992) as examples.

xxix Evidenced in the continued defense of work like Lewin's (See Burnes 2004 and Schein 1996).

${ }^{x x x}$ See also Armenakis, Harris and Field (1999) and Fernandez and Rainey (2006).

xxxi Drazen and Grilli (1990), Kets de Vries and Balazs (1999), Kotter (1995), Lora and Panizza (2002) and Nadler and Nadler (1998).

xxxii Burke-Litwin (1992) and Vollman (1996) both developed tools for diagnosing content challenges related to organizational problems, particularly focused on transformational issues.

xxxiii As discussed in Fernandez and Rainey $(2006,168)$, some theorists downplay the role of agents in effecting change (DiMaggio and Powell 1983; Hannan and Freeman 1984; Scott 2003)

${ }^{\text {xxxiv }}$ Claims like this are evident across the change management literature including Gilley, Dixon and Gilley (2008), Kotter (1995), Lawrence and Lorsch (1967), Pfeffer and Salancik (1978) and even authors 
who believe that agency influence depends significantly on context (Fernandez and Pitts 2007; Van de Ven and Poole 1995).

xxxv Including Stogdill (1948), McClelland (1965), Boyatzis (1982), McCall and Lombardo (1983), Kirkpatrick and Locke (1991) and Kouzes and Posner (2007).

xxxvi The leader has personal attributes that make him (almost always) an almost supernatural, heroic, charismatic quality that inspires trust in followers.

${ }^{\text {xxxvii }}$ Where Nye $(2004,62)$ describes intellectual stimulation as "broadening followers' awareness of situations and new perspectives" and individualized consideration as "providing support, coaching, and developmental experiences to followers rather than treating them as a mere means to an end.”

xxxviii Michael Woolcock's term.

xxxix This is certainly one way of looking at North's (1995) open and closed society approach to development.

${ }^{x l}$ Including the GLOBE study (Den Hartog et al. 1999); Blu et al (2001); Dickson, Den Hartog and Mitchelson (2003), Dorfman 91996) and House, Wright and Aditya (1997).

xli See Dorfman \& Howell (1988), Dorfman et al. (1997), and Kanungo and Mendonca (1996).

xlii See Fiedler (1967).

xliii Terry (2002).

xliv See work by the Leaders, Elites and Coalitions team: http://lecrp.org/publications/research_papers_rps

xlv 42 interviews out of 143.

xlvi We had recordings for all the Africa cases and for Afghanistan.

xlvii Recent work suggests that most studies are biased to one or the other (Cinite, Duxbury and Higgins 2009, 266).

xlviii 58 Interviewees agreed with our prepared statements and 58 agreed that the statement was correct with some addition. 20 disagreed with the statement but indicated there were real problems and the rest would not answer. We observed how problems with weak service delivery resonated as a prominent and serious problem facing Burundi's coalition government, reinforcing the perspective that rapid results interventions addressed a real problem in this context. 